\title{
Evaluating trivalent chromium (CrIII) toxicity on wild terrestrial plants
}

\author{
By \\ Anna Lukina, B.Sc.H.
}

A thesis submitted to the Faculty of Graduate and Postdoctoral Affairs in partial fulfillment of the requirements for the degree of

Master of Science

in

Biology

Specialization in Chemical and Environmental Toxicology

\author{
Carleton University \\ Ottawa, Ontario \\ (C) 2015, Anna Lukina
}




\begin{abstract}
Elevated chromium levels in soil from mining can impact the environment, including plants. Extensive chromite-ore deposits have been discovered in the Ring of Fire region, thus mining may increase. Chromium toxicity on wild plants is poorly understood. Concentration-response experiments were conducted to evaluate the effects of chromium on terrestrial plants. Using artificial soil, seeds of 32 species were exposed to chromium (CrIII) at concentrations $(0-1000 \mathrm{mg} / \mathrm{kg})$ simulating contamination levels. Many plants were not affected at low concentrations, yet higher concentrations were harmful to all species. Secondly, seedbank soils were collected in four habitats near the Ring of Fire and were exposed to chromium at equivalent concentrations as before. More seeds germinated from the lakeshore, with reductions in species/seedlings numbers as chromium increased. This was similar for the upland. This study represents the first step in understanding effects of chromium on plants and could form the basis for risk assessments.
\end{abstract}




\section{Acknowledgements}

First of all, I would like to express my gratitude and appreciation to my supervisor, Dr. Céline Boutin, for not only accepting me as one of her graduate student, but for her support and encouragement, as well as for her patience and constructive mentoring throughout this long two year journey. I would like to thank Dr. Owen Rowland for acting as a co-supervisor. Thanks to Drs. John Arnason and Tyler Smith for agreeing to be committee members, to Drs. Jesse Vermaire and Root Gorelick for acting as an external examiner and a Chair respectively, during my thesis defence. Special thanks to amazing and dedicated graduate administrators, Lisa Chiarelli and Darlene Moss, for all their help on numerous occasions. I would like to extend my appreciation to Philippe Thomas for all his support and valuable advices.

I would like to thank Tracy Coates for allowing Dr. Boutin and myself to personally meet Chief Johnny Yellowhead and Band council members of Nibinamik First Nation. I am extremely grateful to the Chief and Council for giving us the permission to enter their traditional land and collect soil samples during the field work season.

Thanks to David Carpenter, Carly Casey and Simon Gräfe for laboratory assistance. Special thanks to Sara Rodney for all the help with statistical analyses and SAS software. It would have not been easier without Danielle Dowd and her uplifting spirit especially during the thesis writing time. Thanks to Lucas Mundy for providing help with the Ring of Fire map. Also, thanks to Della Bond for answering some of our chemical questions and Guy Savard for allowing me to use some laboratory equipment. 


\section{Table of Contents}

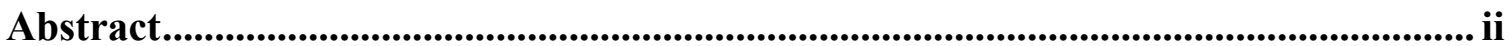

Acknowledgements ................................................................................................

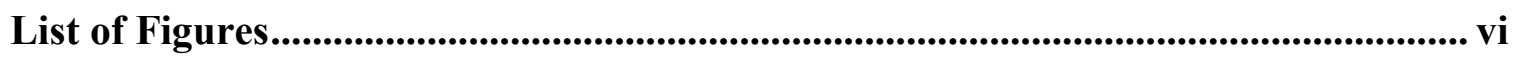

List of Tables ..................................................................................................................... ix

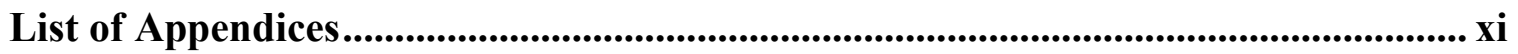

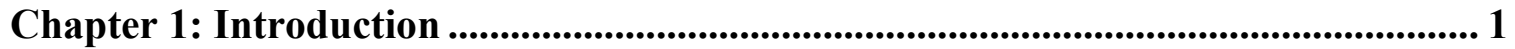

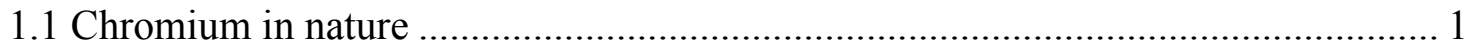

1.2 Uptake of chromium by plants and its toxicity ............................................. 3

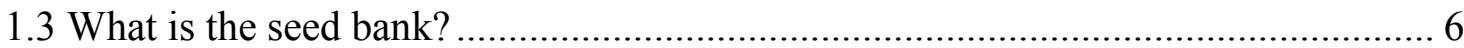

1.4 Study rationale, objectives and predictions ............................................... 7

Chapter 2: Materials and Methods .................................................................... 10

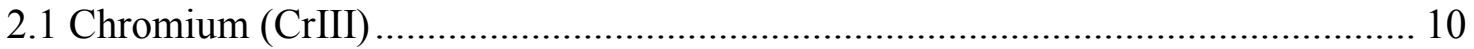

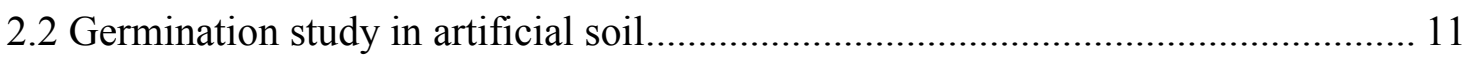

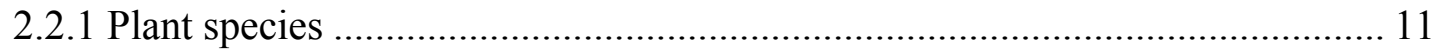

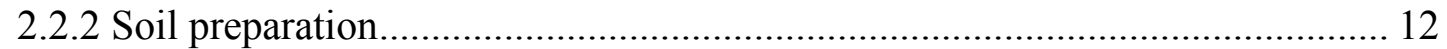

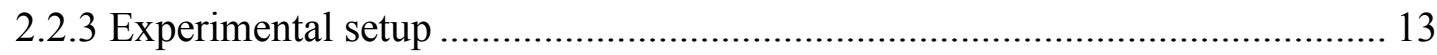

2.2.4 Data collection.................................................................................... 14

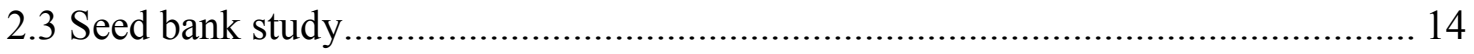

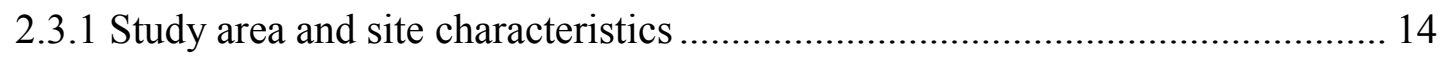

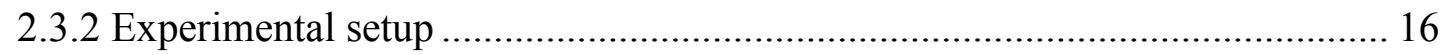

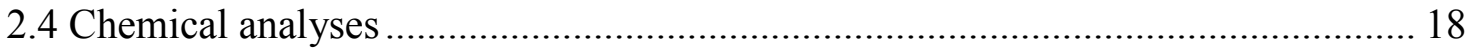

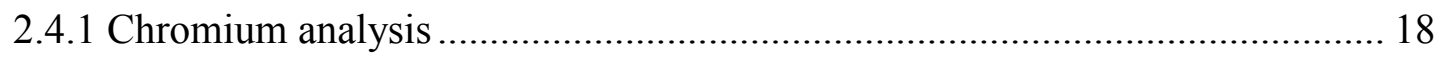

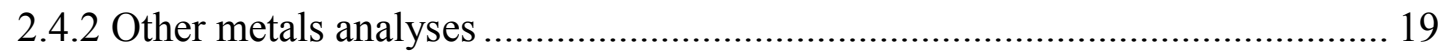

2.4.3 Analyses of physicochemical soil constituents ........................................... 19

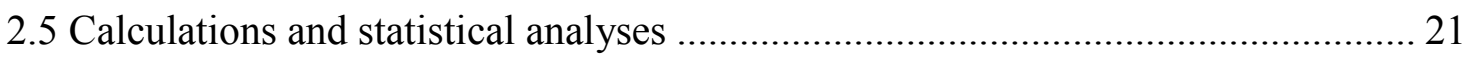

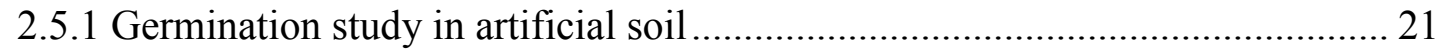

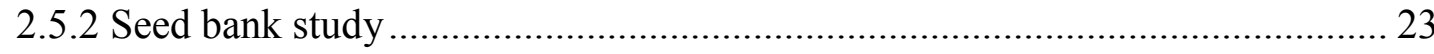

Chapter 3: Results................................................................................................................. 29

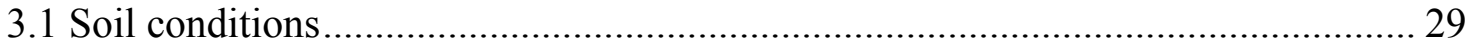

3.2 Effects of chromium (CrIII) on plants in artificial soil ...................................... 30 
3.3 Effects of chromium (CrIII) on plants from the seed bank

Chapter 4: Discussion ................................................................................................ 54

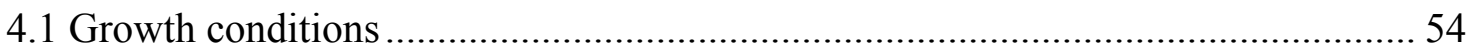

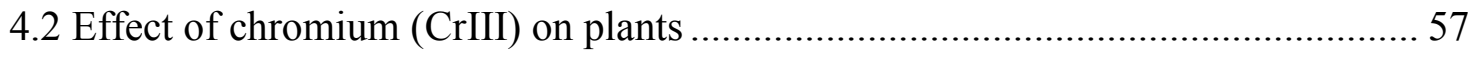

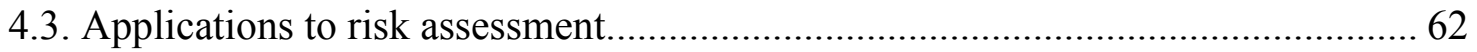

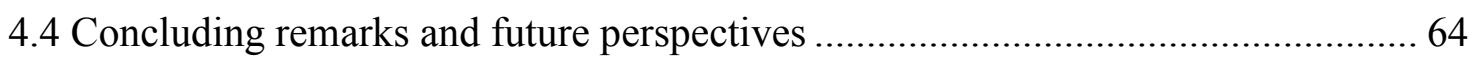

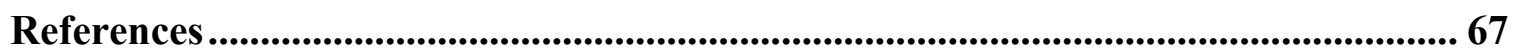




\section{List of Figures}

Figure 1: Map of the Ring of Fire [highlighted in red], Northern Ontario, Canada, where large chromite deposits were discovered and mining will occur in the near future (map created in ArcView version 10.3 by L. Mundy and A. Lukina)..........................9

Figure 2: Map showing the four study sites (S1-Bucheski Lake, S2-Upland, S3-Wetland, and S4-Winisk River) located in Nibinamik (in Oji Cree - Summer Beaver in English translation) First Nations traditional/reserve land, Ontario, Canada and where soils were collected during field work (September 11 and 12, 2014) ..........................28

Figure 3: Levels of chromium in prepared artificial soil during the concentrationresponse experiment. Following completion of the experiment, soil samples of all five independent replicates were pooled separately for all four concentrations, including controls for each tested plant. The measured chromium levels [solid line] in soil samples were slightly higher than the nominal levels [dashed line]. The Determination Coefficient for the measured concentrations $\left(\mathrm{R}^{2}=0.898\right)$ shows that all points accurately fit the statistical model with minimum variability

Figure 4: Number of non-stratified plant species exhibiting significant negative effects (as compared to the controls) on total germination [striped bars] and healthy seedlings [grey bars] assessed via pairwise Fisher's Exact test (refer to Appendix 4 for detailed results). All 32 species were exposed to chromium for one month during the concentration-response experiment in the growth chambers. Poor health was defined based on seedlings with reduced root length and hypocotyl height, light discolorations, wilting and/or rotting. In addition, the significant negative effect of chromium on the cumulative speed of germination [red line] (seed germination only) was assessed via either one-way ANOVA or Kruskal-Wallis tests. The lowest observed effect concentration (LOEC) of chromium on the rate of germination of each species was estimated from a significant difference using either Dunnett's or Savage post-hoc tests. Refer to Appendix 5 for detailed results............................................ 39

Figure 5: Number of stratified plant species exhibiting significant negative effects (as compared to the controls) on total germination [striped bars] and healthy seedlings [grey bars] assessed via pairwise Fisher's Exact test (refer to Appendix 4 for detailed results). All nine species were exposed to chromium during a four to eight week stratification period (refer to Table 1) in a dark refrigerator at $4{ }^{0} \mathrm{C}$, as well as for a one month concentration-response experiment in the growth chambers. Poor health was defined based on seedlings with reduced root length and hypocotyl height, light discolorations, wilting and/or rotting. In addition, the significant negative effect of chromium on the cumulative speed of germination [red line] (seed germination only) was assessed via 
either one-way ANOVA or Kruskal-Wallis tests. The lowest observed effect concentration (LOEC) of chromium on the rate of germination of each species was estimated from a significant difference using either Dunnett's or Savage post-hoc tests. Refer to Appendix 5 for detailed results.....................................40

Figure 6: Species sensitivity ranks using estimated EC25s (effective concentration causing $25 \%$ reduction in species germination) for the tested species exposed to CrIII during the concentration-response experiment either without stratification [A] or with stratification [B] treatment. Tested species were separated into native herbs [highlighted in red], native woody [highlighted in green], introduced crops [in bold] and introduced forbs [in black]. Dashed red lines represent the natural range of chromium $(10-100 \mathrm{mg} \mathrm{kg}$ ${ }^{-1}$ ) in soil. The EC25 could not be estimated in four cases (three species) since monotonic concentration-response effect was not found, and the non-stratified P. banksiana had EC25 greater than the maximum concentration (refer to Appendix 6 for details).......43

Figure 7: Significant positive trend between seed sizes of tested plant species and estimated EC25s (effective concentration causing 25\% reduction in species germination) $\left(\mathrm{R}^{2}=0.150\right)$. An average of pre- and post-contamination EC25 was calculated for eight species (excluding $S$. canadensis which was tolerant in both conditions). Additionally, EC25 could not be estimated for three cases, including $P$. tremuloides, H. perforatum, and $P$. banksiana. Ipomoea purpurea was also excluded from the analysis due to its very large seed size compared to the rest of the plant species..........................45

Figure 8: Average number of plant species and seedlings from the seed bank soils collected in the shores of Bucheski Lake in Nibinamik traditional/reserve land, Ontario. Short-term exposure: soil was stratified for one month and then was exposed to three chromium (CrIII) concentrations plus controls in a growth chamber starting from October $21^{\text {st }}, 2014$ to April $21^{\text {st }}, 2015$. Long-term exposure: soil was exposed to three chromium concentrations during stratification for one month prior to the concentration-response experiment in the growth chamber. Total numbers of species are indicated in red and total numbers of seedlings in black. Error bars represent standard errors.

Figure 9: Average number of plant species and seedlings from the seed bank soils collected in the upland woody area in Nibinamik traditional/reserve land, Ontario. Shortterm exposure: soil was stratified for one month and then was exposed to three chromium (CrIII) concentrations plus controls in a growth chamber starting from October $21^{\text {st }}, 2014$ to April 21 ${ }^{\text {st }}$, 2015. Long-term exposure: soil was exposed to three chromium concentrations during stratification for one month prior to the concentration-response experiment in the growth chamber. Total numbers of species are indicated in red and total numbers of seedlings in black. Error bars represent standard errors...................50 
Figure 10: Average number of plant species and seedlings from the seed bank soils collected in the wetland habitat in Nibinamik traditional/reserve land, Ontario. Short-term exposure: soil was stratified for one month and then was exposed to three chromium (CrIII) concentrations plus controls in a growth chamber starting from October $27^{\text {th }}, 2014$ to April $27^{\text {th }}$, 2015. Long-term exposure: soil was exposed to three chromium concentrations during stratification for one month prior to the concentration-response experiment in the growth chamber. Total numbers of species are indicated in red and total numbers of seedlings in black. Error bars represent standard errors....................51

Figure 11: Average number of plant species and seedlings from the seed bank soils collected at the banks of Winisk River in Nibinamik traditional/reserve land, Ontario. Short-term exposure: soil was stratified for one month and then was exposed to three chromium (CrIII) concentrations plus controls in a growth chamber starting from October $27^{\text {th }}, 2014$ to April $27^{\text {th }}, 2015$. Long-term exposure: soil was exposed to three chromium concentrations during stratification for one month prior to the concentration-response experiment in the growth chamber. Total numbers of species are indicated in red and total numbers of seedlings in black. Error bars represent standard errors....................52 


\section{List of Tables}

Table 1: Characteristics of 32 plant species from 18 botanical families tested in the chromium (CrIII) concentration-response experiment in artificial soil. Species scientific names were obtained from the USDA Plants Database (http://www.plants.usda.gov/java/) and from the Database of Vascular Plants of Canada (VASCAN) (http://data.canadensys.net/vascan/search). Species are separated into gymnosperms and angiosperms, as well as into monocots and dicots. Dicots are further separated into woody (i.e. trees and shrubs), herbaceous non-crops and crops. Lifespan is represented as annual (A), biennial (B) and perennial (P) (http://www.plants.usda.gov/java/). Habitat was divided into several categories, as follows: OBL (obligate wetland) - plant species almost always found in wetlands under natural conditions ( $>90 \%$ probability), FACW (facultative wetland) - usually found in wetlands, but occasionally found in non-wetlands (67-89\%), FAC (facultative) - equally likely to occur in wetlands or non-wetlands (34$66 \%$ ), FACU (facultative upland) - occasionally occurs in wetlands, but usually found in non-wetlands (1-33\%), and UPL (obligate upland) - almost never found in wetlands under natural conditions $(<1 \%)$, and status was divided to either $\mathrm{N}=$ Native or $\mathrm{I}=$ Introduced (Oldham et al., 1995). N status means that plant species are native to Ontario. The seeds of tested plants were purchased from commercial suppliers and grown within the laboratory environment in artificial soil. Stratification for nine species occurred in a dark refrigerator at $4{ }^{0} \mathrm{C}$. Average $\%$ germination was calculated from seeds germinating in the controls; * represents the \% germination of stratified seeds. STD error stands for standard error................................................................ 24

Table 2: Soil attributes of four sampled sites including lake, upland, wetland and river located in Nibinamik traditional/reserve land, Northern Ontario, Canada................38

Table 3: Percent germination at 250, 500 and $1000 \mathrm{mg} \mathrm{kg}^{-1}$ chromium (CrIII) concentrations for non-stratified seeds/stratified seeds each normalized to their control percent germination. Seeds were exposed to chromium either for a one month concentration-response experiment in the growth chambers (non-stratified) or seeds were exposed to chromium during a four to eight week stratification treatment (refer to Table 1) and a one month concentration-response experiment (stratified). To test for the difference in responses between stratified and non-stratified seeds, Mantel-Haenszel analysis $\left(\mathrm{X}^{2}{ }_{\mathrm{MH}} / \mathrm{df} / \mathrm{p}\right.$-value) was used. Total germinated seeds [in clear] and only healthy seedlings evaluated via visual assessment [in grey] are presented. Significant statistical effect is highlighted in bold.

Table 4: Germination of plant species with diverse taxonomic and ecological traits when exposed to 250, 500 and $1000 \mathrm{mg} \mathrm{kg}^{-1}$ chromium (CrIII) concentrations as compared to 
controls during the concentration-response experiment. Mantel-Haenszel analysis $\left(\mathrm{X}^{2}{ }_{\mathrm{MH}} / \mathrm{df} / \mathrm{p}\right.$-value) was used to test for the difference in responses using all germinating seeds [in clear] and only using healthy seedlings determined via visual assessment [in grey]. Significant differences are highlighted in bold.............................44

Table 5: Characteristics of 38 plant species from 20 botanical families that emerged from the seed bank soils from Nibinamik traditional/reserve land, Ontario, Canada. Twenty four species from 15 families emerged during the concentration-response experiment. The seed bank soils containing those seeds were stratified for a one month in a dark refrigerator at $4{ }^{0} \mathrm{C}$ and then placed in the growth chamber for the experiment that occurred from October, 2014 to April, 2015. Additionally, 14 species from 11 families emerged from large containers with uncontaminated seed bank soils, which were used to aid in identifying emerged species and for further comparison to seedlings from Petri dishes. Species scientific names were obtained from the USDA Plants Database (http://www.plants.usda.gov/java/) and from the Database of Vascular Plants of Canada (VASCAN) (http://data.canadensys.net/vascan/search). Species are separated into gymnosperms and angiosperms as well as into monocots and dicots. Dicots are further separated into woody (i.e. trees and shrubs) and herbs. Lifespan is represented as annual (A), biennial (B) and perennial (P) (http://www.plants.usda.gov/java/). Habitat was divided into several categories, as follows: OBL (obligate wetland) - plant species almost always found in wetlands under natural conditions ( $>90 \%$ probability), FACW (facultative wetland) - usually found in wetlands, but occasionally found in non-wetlands (67-89\%), FAC (facultative) - equally likely to occur in wetlands or non-wetlands (34$66 \%$ ), FACU (facultative upland) - occasionally occurs in wetlands, but usually found in non-wetlands (1-33\%), and UPL (obligate upland) - almost never found in wetlands under natural conditions $(<1 \%)$ (Oldham et al., 1995). $\mathrm{N}$ status means that plant species are native to Ontario......................................................... 46

Table 6: Summary of Poisson regression statistical results (Wald Chi-Square $/ \mathrm{df} / \mathrm{p}$-value) under the Generalized Linear Model framework for the plant species and seedlings emerging from the seed bank soils of four sampled sites from Nibinamik traditional/reserve land, Ontario, Canada. Soils were exposed to three chromium (CrIII) concentrations plus controls during the concentration-response experiment. To test for possible difference in responses, soils were exposed to chromium before and after stratification (condition). In addition, an interaction between concentrations and condition was also considered. Significant differences are highlighted in bold...................53 


\section{List of Appendices}

Appendix 1: Levels of 28 metals (in $\mathrm{mg} \mathrm{kg}^{-1}$ ) in the artificial soil used for the concentration-response experiment (chemical analyses were performed by the RPC laboratory, RPC, New Brunswick). Reporting limit [RL] refers to a minimum amount of analytes detected and measured within the soil medium. The average natural levels of metals in the worldwide soils (obtained from several literature sources) and the soil quality guidelines (obtained from the "Soil Quality Guidelines for the Protection of Environmental and Human Health". Ontario: Canadian Council of Ministers of the Environment, CCME, 2015, via http://st-ts.ccme.ca/en/index.html) are presented.......77

Appendix 2: Levels of 28 metals (in $\mathrm{mg} \mathrm{kg}^{-1}$ ) in the seed bank soil samples from four sites (i.e. Bucheski Lake, upland, wetland, and Winisk River) in Nibinamik traditional/reserve land, Ontario (chemical analyses were performed by the RPC laboratory, RPC, New Brunswick). Reporting limit [RL] refers to a minimum amount of analytes detected and measured within the soil medium. The average natural levels of metals in the worldwide soils (obtained from several literature sources) and the soil quality guidelines (obtained from the "Soil Quality Guidelines for the Protection of Environmental and Human Health". Ontario: Canadian Council of Ministers of the Environment, CCME, 2015, via http://st-ts.ccme.ca/en/index.html) are presented.......79

Appendix 3: Average total percent germination for healthy seedlings [green bars] and for unhealthy seedlings [red bars], as well as average speed of seed germination [dashed line] for non-stratified/stratified seeds grown in soils contaminated with increasing levels of chromium (CrIII). All 32 species (non-stratified) were exposed to chromium for one month during the concentration-response experiment in the growth chambers. All nine species (stratified) were exposed to chromium during a four to eight week stratification period (Table 1) in a dark refrigerator at $4{ }^{0} \mathrm{C}$, as well as for a one month concentrationresponse experiment in the growth chambers. Percent germination and speed of germination decreased with increasing CrIII concentrations $\left(0-1000 \mathrm{mg} \mathrm{kg}^{-1}\right)$ in artificial soil. Error bars represent standard errors. Axes for both percent germination and speed of germination vary amongst the tested species. 81

Appendix 4: Summary of the statistical results for total germination [in clear] and seedling health [in grey] of 32 tested plant species exposed to chromium (CrIII) in the concentration-response experiments without stratification and nine plant species exposed to CrIII in the concentration-response experiments with stratification. Cochran-Armitage trend test (Z-statistics/p-value) was conducted to test for trends in response amongst chromium treatments plus controls. Pairwise Fisher's Exact Test (p-value) was performed to compare responses in each independent CrIII treatment to controls. Significant 
differences amongst chromium concentrations for all tested plants are highlighted in bold................................................................................

Appendix 5: Summary of the statistical results for speed of total germination (SG) of seeds of 32 plant species exposed to CrIII in the concentration-response experiments without stratification and nine plant species exposed to CrIII in the concentrationresponse experiments with stratification. To test if chromium had an effect on how fast seeds germinate over the experiment period, either one-way ANOVA (F-value/df/pvalue) or Kruskal-Wallis* $\left(\mathrm{X}^{2}\right.$-value/df/p-value) tests were conducted. Significant differences were further tested with either Dunnett's or Savage post-hoc tests (Iman \& Conover, 1987). Significant differences for SG are highlighted in bold. The lowest observed effect on speed of germination at tested chromium concentration (in $\mathrm{mg} \mathrm{kg}^{-1}$ ) was estimated using the post-hoc tests. $\mathrm{N} / \mathrm{E}$ represents the cases where no significant effect amongst chromium treatments was observed................................106

Appendix 6: Effective concentrations (EC10, EC25 and EC50) causing 10\%, 25\% and $50 \%$ reduction in species germination are presented with confidence intervals (CI). Probit model (with appropriate distribution) or non-parametric interpolation method (ICPIN) (Norberg-King, 1993) were used to calculate the EC values. N/E represents the four cases where non-monotonic concentration-response of species to chromium was observed. Dashes (-) represents the cases for five tested plant species where calculated ECs were exceeding the maximum concentrations tested.

Appendix 7: Summary of emerged plant species in large containers (uncontaminated soil) and concentration-response Petri dishes (chromium contaminated soil) from the seed bank soils collected near the shores of Bucheski Lake, Nibinamik, Ontario. Acontamination refers to contaminating the soil with four concentrations (i.e. control - [0], 250,500 and $1000 \mathrm{mg} \mathrm{kg}^{-1}$ ) after one month stratification treatment. B-contamination refers to contaminating the soil with the same four concentrations including controls prior to one month stratification treatment. The concentration-response experiment occurred in

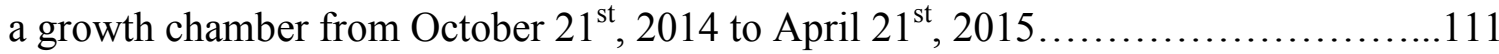

Appendix 8: Summary of emerged plant species in large containers (uncontaminated soil) and concentration-response Petri dishes (chromium contaminated soil) from the seed bank soils collected in the uplands of boreal forest, Nibinamik, Ontario. A-contamination refers to contaminating the soil with four concentrations (i.e. control - [0], 250, 500 and $1000 \mathrm{mg} \mathrm{kg}^{-1}$ ) after one month stratification treatment. B-contamination refers to contaminating the soil with the same four concentrations including controls prior to one month stratification treatment. The concentration-response experiment occurred in a

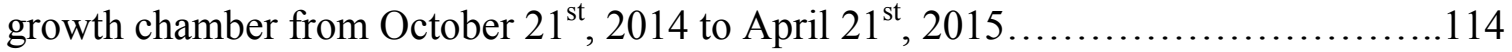


Appendix 9: Summary of emerged plant species in large containers (uncontaminated soil) and concentration-response Petri dishes (chromium contaminated soil) from the seed bank soils collected in the wetland areas, Nibinamik, Ontario. A-contamination refers to contaminating the soil with four concentrations (i.e. control - [0], 250, 500 and $1000 \mathrm{mg}$ $\mathrm{kg}^{-1}$ ) after one month stratification treatment. B-contamination refers to contaminating the soil with the same four concentrations including controls prior to one month stratification treatment. The concentration-response experiment occurred in a growth

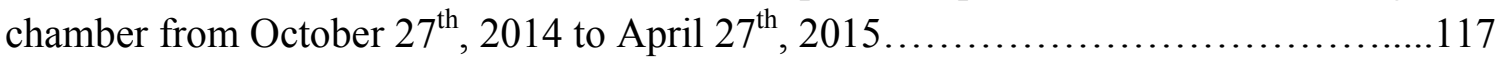

Appendix 10: Summary of emerged plant species in large containers (uncontaminated soil) and concentration-response Petri dishes (chromium contaminated soil) from the seed bank soils collected near the banks of Winisk River, Nibinamik, Ontario. Acontamination refers to contaminating the soil with four concentrations (i.e. control - [0], 250,500 and $1000 \mathrm{mg} \mathrm{kg}^{-1}$ ) after one month stratification treatment. B-contamination refers to contaminating the soil with the same four concentrations including controls prior to one month stratification treatment. The concentration-response experiment occurred in

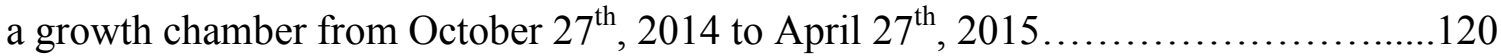




\section{Chapter 1: Introduction}

Mining of chromium and its use in industrial activities, including production of alloy and stainless steel, leather tanning, paper and pulp manufacturing, wood preservation, and other chemical and metallurgical processes, have raised major concerns worldwide due to the risk of environmental contamination and possible effects on the food chain, from primary producers to human beings (Dhal et al., 2013). The worldleading countries in chromium mining are South Africa, Kazakhstan, India and China (Papp, 2003; ICDA, 2011). In Northern Ontario, Canada, extensive and high grade chromite $\left(\mathrm{FeCr}_{2} \mathrm{O}_{4}\right)$ deposits were discovered in the Ring of Fire region (latitude $52^{0} 57^{\prime} \mathrm{N}$, longitude $87^{0} 22^{\prime} \mathrm{W}$ ), located roughly $1200 \mathrm{~km}$ northwest of Toronto (Figure 1).

\subsection{Chromium in nature}

Chromium is prevalent in many environments, including geologic (soil and rocks), aquatic (surface and underground), and atmospheric compartments. Chromium is found in the Earth's crust with mean levels ranging between 126 and $185 \mathrm{mg} \mathrm{kg}^{-1}$ (Kabata-Pendias, 2011). The average level of chromium in soil worldwide is around 10$100 \mathrm{mg} \mathrm{kg}^{-1}$ with a mean of $60 \mathrm{mg} \mathrm{kg}^{-1}$, and is present in exceptionally large quantities in serpentine soils (McKeague \& Wolynetz, 1980; Kabata-Pendias, 2011; Alloway, 2013). Therefore, the level of chromium depends on the bedrock, including mafic and ultramafic (170-3400 $\left.\mathrm{mg} \mathrm{kg}^{-1}\right)$, igneous and sedimentary $\left(5-120 \mathrm{mg} \mathrm{kg}^{-1}\right)$, calcareous $(5-$ $\left.16 \mathrm{mg} \mathrm{kg}^{-1}\right)$, sandstone $\left(20-40 \mathrm{mg} \mathrm{kg}^{-1}\right)$ and argillaceous rocks (80-120 $\mathrm{mg} \mathrm{kg}^{-1}$ ) (Kabata-Pendias, 2011; Alloway, 2013). Chromium in soil exists in both chromite and 
crocoite $\left(\mathrm{PbCrO}_{4}\right)$ minerals (Zayed \& Terry, 2003). Normal levels of chromium in the hydrosphere vary little within compartments, surface waters containing $0.5-2.0 \mu \mathrm{g} \mathrm{L}^{-1}$, groundwater at $<1.0 \mu \mathrm{g} \mathrm{L}^{-1}$, and seawater spanning 0.04-0.5 $\mu \mathrm{g} \mathrm{L}^{-1}$ (WHO, 2003). Chromium is found in the Great Lakes, such as Lake Ontario and Lake Erie with $0.81 \mu \mathrm{g}$ $\mathrm{L}^{-1}$ and $0.39 \mu \mathrm{g} \mathrm{L}^{-1}$ levels, respectively (Rossmann \& Barres, 1988). The total chromium levels in sediments may range from trace amounts to $2085 \mathrm{mg} \mathrm{kg}^{-1}$, and relatively high levels were detected in the fine-grained sediments at St. Mary's River, Ontario, fluctuating from 0 to $31000 \mathrm{mg} \mathrm{kg}^{-1}$ from prolonged wastewater discharges of nearby industries (Pawlisz et al., 1997) and also due to the natural tendency of sediments to absorb heavy metals (Peng et al., 2009). Chromium may also be found in the air (1-545 $\mu \mathrm{g} \mathrm{m}^{-3}$ ), with the main sources being industrial emissions and volcanic eruptions (Pawlisz et al., 1997).

Elemental chromium is a transition metal with atomic number 24 and a relative atomic mass of 51.996. The most stable and commonly found forms of chromium in nature are trivalent (CrIII) and hexavalent $(\mathrm{CrVI})$; these two forms have differing physical and chemical characteristics. Hexavalent chromium is more soluble and can be easily transferred within and between environments (Fendorf, 1995). In soils, manganese oxides (e.g. pyrolusite, hausmannite, and birnessite) may oxidize the trivalent form of chromium to hexavalent; whereas ferrous iron, gallic acid, soil organic matter, and several sulfides convert the hexavalent form to trivalent (Rai et al., 1989; Fendorf, 1995). Sources of both forms of chromium vary: CrIII is abundantly present in chromite, while CrVI naturally exists in crocoite (Zayed \& Terry, 2003). As for man-made inputs, mining 
of chromite ore is associated with CrIII pollution, whereas chrome plating and stainless steel production are associated with CrVI pollution.

\subsection{Uptake of chromium by plants and its toxicity}

Chromium is not an essential nutrient for plant growth and health. A few studies have shown that chromium in relatively small quantities may promote plant productivity, but this is disputed as there is a shortage of data to support this statement (Peralta et al., 2001; Gardea-Torresdey et al., 2005; Amin et al., 2013). Chromium mainly moves up from roots to shoots through the xylem of the plant (Skeffington et al., 1976). Uptake of chromium involves two mechanisms: active and passive. The uptake of CrIII within plant tissues is passive via binding sites in cell walls, whereas CrVI requires an active energydependent process and with the possible help of transporters (Skeffington et al., 1976; Appenroth et al., 2008). Uptake and accumulation of chromium by plants depends on several factors, including plant species (Liu et al., 2011; Peralta-Videa et al., 2009), chromium concentration, frequency of exposure, and type of soil (Fernandes et al., 2002; Marti et al., 2007). Higher chromium concentrations are often found in plant roots and less so in aboveground tissues (Srivastava et al., 1999; Davies et al., 2002). Low, naturally present amounts $\left(<1-10 \mathrm{mg} \mathrm{kg}^{-1}\right.$ dry weight) of trivalent chromium can be found in many crops (e.g. Brassica oleracea L. (Brassicaceae family) and Solanum tuberosum L. (Solanaceae)), medicinal herbs (e.g. Trigonella foenum-graecum L. (Fabaceae) and Salvia officinalis L. (Lamiaceae)), spices and seasonings (e.g. Piper nigrum L. (Piperaceae) and Capsicum annuum L. (Solanaceae)) that have been grown on uncontaminated soils (Katz \& Salem, 1994). 
Chromium may cause delays in seed germination, stunted plant growth, reduced biomass, chlorosis (discoloration), necrosis (wilting) and death. Competition for the same binding sites may occur between chromium and other essential nutrients, including calcium (Cervantes et al., 2001; Scoccianti et al., 2006), sulfur and iron (Skeffington et al., 1976; Schmidt, 1996), boron (Moral et al., 1996), phosphorus, potassium (Davies et al., 2002), manganese, zinc, and possibly copper (Abreu et al., 2002; Panda \& Choudhury, 2005). Chromium is known to affect metabolic processes, including pigment alterations (e.g. total chlorophyll content and anthocyanin) (Scoccianti et al., 2006; Pandey et al., 2009). Many studies have shown that chromium supresses the function and regulation of several proteins (Panda \& Choudhury, 2005; Labra et al., 2006), including antioxidant enzymes (Sinha et al., 2005), disrupts root plasma membrane (Pandey et al., 2009), increases additional metabolites (e.g. glutathione and ascorbic acid) (Kranner \& Colville, 2011), and causes chromosomal impairments within plant tissues (Cervantes et al., 2001).

Phytotoxicity of chromium has been studied in crops and species of economic value within controlled experimental environments (Huffman \& Allaway, 1973; Zayed et al., 1998; Labra et al., 2006). Chromium (CrIII) induced chlorosis on foliage of Helianthus annuus L. (Asteraceae) at a concentration of $12 \mathrm{mmol}$ in $200 \mathrm{~mL}(1.9 \mathrm{~g}$ of $\mathrm{CrCl}_{3}$ ) of soil by disrupting stomatal conductance and decreasing levels of certain macronutrients (i.e. phosphorus and potassium) (Davies et al., 2002). A negative effect of chromium on the levels of micronutrients (i.e. zinc and manganese), which are essential for plant growth, was observed when Raphanus sativus L. (Brassicaceae) was exposed to 
trivalent chromium in soil $\left(0-100 \mathrm{mg} \mathrm{kg}^{-1}\right)$ (Abreu et al., 2002). The decrease in overall plant biomass of Cicer arietinum L. (Fabaceae) was also visible following species exposure to CrVI (136 $\mathrm{mg} \mathrm{kg}^{-1}$ ) in soil (Khan et al., 2012). Marchiol et al. (2004) found that the two-week old seedlings of $R$. sativus and Brassica napus L. (Brassicaceae) experienced decreased growth and appearance of necrosis on the true leaves when the species were grown in agricultural soil contaminated by irrigation waters containing relatively low chromium levels $\left(165 \mathrm{mg} \mathrm{kg}^{-1}\right)$. CrVI caused delays in growth and changes in metabolic processes of Zea mays L. (Poaceae) at $100 \mathrm{ppm}\left(\mathrm{mg} \mathrm{kg}^{-1}\right)$ level in soil (Labra et al., 2006). Prasad et al. (2010) determined that essential oil and fresh herbage yields were affected when mint species (i.e. Mentha arvensis L., M. piperita L., and M. citrata L. - all listed species are from Lamiaceae family) were exposed to CrVI at $30-60 \mathrm{mg} \mathrm{kg}^{-1}$ concentrations in soil.

Chromium, in many cases, is detrimental to seed germination, especially at high concentrations. Parr and Taylor (1982) reported that exposure of Phaseolus vulgaris L. (Fabaceae) to CrVI at $500 \mathrm{ppm}\left(\mathrm{mg} \mathrm{kg}^{-1}\right)$ concentration in soil significantly inhibited species germination. Germination of Hibiscus esculentus L. (Malvaceae) seeds exposed to $\mathrm{CrVI}$ in soil was not markedly affected at $0.5-25 \mathrm{mg} \mathrm{kg}^{-1}$ concentrations compared to higher (50 and $100 \mathrm{mg} \mathrm{kg}^{-1}$ ) levels (Amin et al., 2013). Lopez-Luna et al. (2009) found decreases in germination of both Sorghum bicolor x Sorghum sudanense L. and Triticum aestivum L. grown in soil and exposed to CrIII at $>500 \mathrm{mg} \mathrm{kg}^{-1}$ concentrations, yet germination of Avena sativa L. was not affected below $4000 \mathrm{mg} \mathrm{kg}^{-1}$ concentration (all listed species are from Poaceae family). 


\subsection{What is the seed bank?}

A soil seed bank is a collection of buried, dormant seeds found naturally in soils. The formation of a seed bank comes from a combination of two sources, including when plants shed their seeds during the growing season, and from neighbouring habitats (e.g. being delivered by wind, water or wildlife). Seeds can remain intact and viable in soil for a number of years awaiting perfect conditions to germinate (i.e. soil moisture and oxygen contents, temperature ranges, and light for some species) (Knox, 1997; Brändel, 2006; Honda, 2008). For example, seedling emergence of plants growing near bogs, river banks or other wetland habitats is directly dependent on water level fluctuations and seeds may remain dormant during moisture-poor conditions. Brändel (2006) discovered that seed germination of species from the Lamiaceae family (i.e. Lycopus europaeus L., Mentha aquatica L., and Stachys palustris L.) significantly increased with temperatures exceeding $30{ }^{\circ} \mathrm{C}$. Importantly, a soil seed bank may be used as a seed source for vegetation recovery and restoration following natural or man-made disturbances (Armesto \& Pickett, 1985; Klimkowska et al., 2010).

There is a considerable difference in species composition between the aboveground vegetation and the seed flora in soils. Boutin (2006) found no difference in the weed species diversity for seed banks collected at agricultural fields and adjacent woody hedgerows, but a significant difference in vegetation with more weeds growing in the fields and much less in the hedgerows. Additionally, aboveground vegetation is more susceptible to environmental conditions (i.e. droughts, fires, flooding, competitive interactions between species, diseases, herbivores grazing, and pest outbreak). Seeds can 
also be affected by fungal diseases, decay or just age with time, as well as the resulting soil and water contamination arising from persistent man-made disturbances which may have a direct effect on seeds in seed bank soils. Harper (1977) stated that seeds of grasses and forbs may be more abundant in seed banks than seeds of tree species, since it can take over a decade for a tree to produce seeds. The lifespan of a parent plant and seed size are also important characteristics of the formation and persistence of a seed bank, including annuals, biennials, and small-sized seeds being the most common, but depending on the habitat (i.e. agricultural fields versus woodland) (Harper, 1977; Honda, 2008). However, Armesto and Pickett (1985) argued that seed bank formation is directly dependent on the frequency of disturbances and habitat conditions. Likewise, Beatrijs and Olivier (2008) stated that species abundance and composition were more pronounced in grassland habitats followed by the wetland and forest habitats, and scarcer in heathlands.

\subsection{Study rationale, objectives and predictions}

There is a dearth of toxicological studies dealing with native species shaping natural communities (Olszyk et al., 2008; Prasad et al., 2010). With regards to chromium, many studies were more concerned with the effects of hexavalent chromium on crops and economically important herbs (Lahouti \& Peterson, 1979; Zayed et al., 1998; Sharma et al., 2005; Zou et al., 2006; Gill \& Saggoo, 2010; Stasinos \& Zabetakis, 2013) since the hexavalent form is more harmful at lower concentrations compared to the trivalent form. However, mining of chromite ore is associated with CrIII contamination. It is important to understand how plants cope with heavy metal pollution in order to identify plant species with the highest sensitivity to chromium and then be able to predict 
impacts at the individual, population, and community levels. The overall objective of the present study was to perform concentration-response tests to determine chromium toxicity on a wide range of terrestrial plants with diverse ecological characteristics (i.e. botanical families, taxonomic group, lifespan, growth habit, native/introduced status, and habitat). Introduced species status refers to those species that arrived in North America with the European settlements since the $17^{\text {th }}$ century. Seeds were exposed to a suite of concentrations of chromium (CrIII), including natural levels found in the environment and those simulating different levels of possible contamination that may originate from anthropogenic activities (e.g. mining of chromite). Two types of experiments were conducted, one using seeds grown in artificial soil and the second with seeds present in the seed bank from soils collected near the Ring of Fire in Northern Ontario, Canada. The objective of the first experiment was to assess the effects of CrIII on seed germination and seedling health. We expected CrIII to have a negative effect on plants, but at varying concentrations depending on the species. The objective of the second experiment was to assess the effects of CrIII on seeds from seed bank soils collected near the Ring of Fire. We expected CrIII to have negative effects on plants, but depending on physicochemical properties of soil and types of plants. Some of the plants may have already developed some tolerance to chromium due to existing chromite ore deposits in the Ring of Fire. 


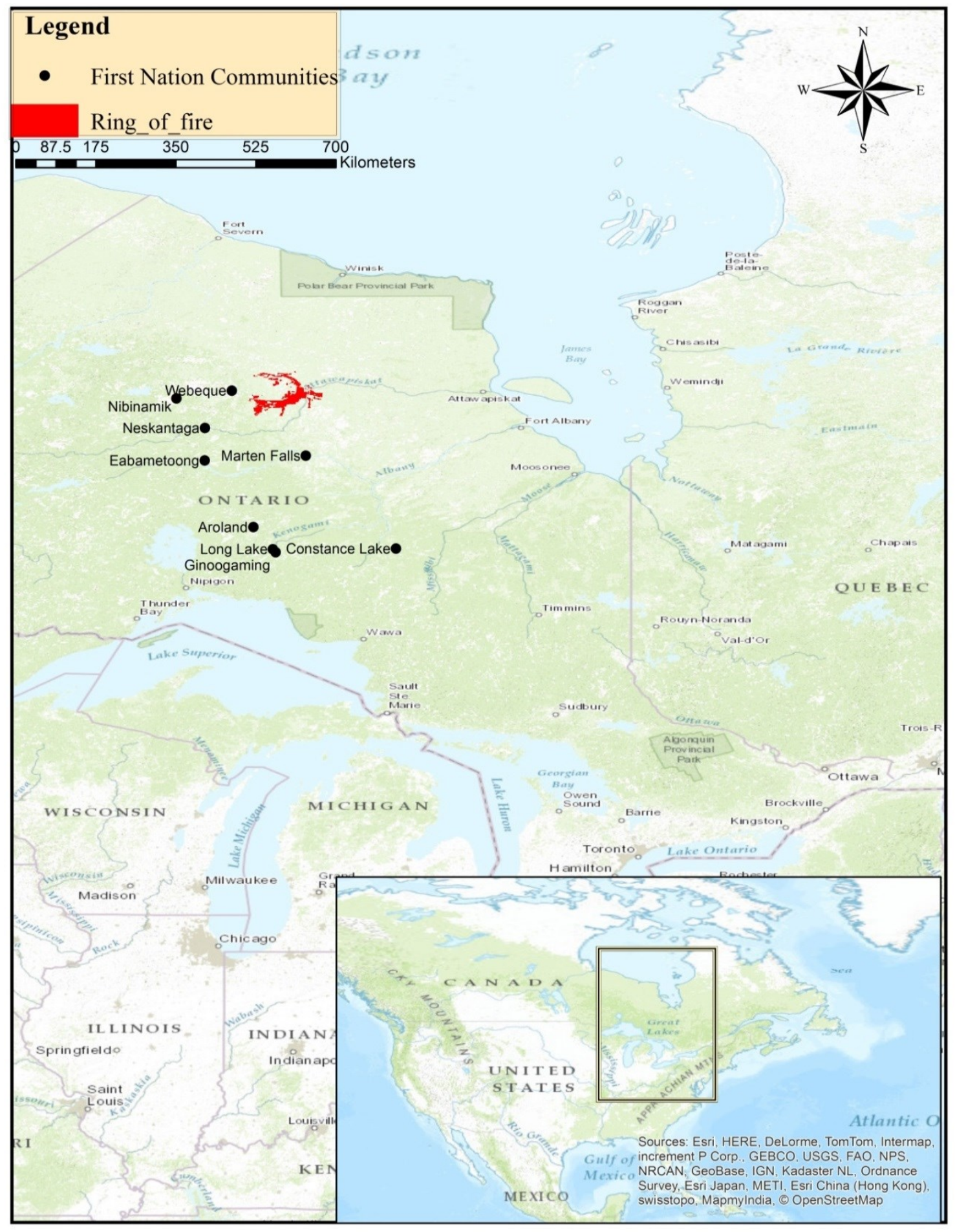

Figure 1: Map of the Ring of Fire [highlighted in red], Northern Ontario, Canada, where large chromite deposits were discovered and mining will occur in the near future (map created in ArcView version 10.3 by L. Mundy and A. Lukina). 


\section{Chapter 2: Materials and Methods}

Concentration-response experiments with chromium (CrIII) were conducted in two growth chambers (Conviron, PGW36, Winnipeg, Manitoba) situated at the National Wildlife Research Centre (NWRC, Environment Canada), Ottawa, Ontario, Canada. Experiments with seeds grown in artificial soil occurred between October 2013 and October 2014. The collection of soil samples for the seed bank study occurred in Nibinamik (Summer Beaver) traditional/reserve territory, Northern Ontario from September $11^{\text {th }}$ to $12^{\text {th }}, 2014$ (Figures 1 and 2). Experiments with seeds present in the seed bank samples were performed between October 2014 and April 2015 in the NWRC growth chambers. Artificial lights used in the growth chambers were a combination of incandescent and fluorescent lamps and followed a 16:8 hour day/night cycle, with an average photosynthetic active radiation of $314 \pm 4 \mu \mathrm{mol}$ photons $\mathrm{m}^{-2} \mathrm{~s}^{-1}$. The estimated average temperature within the chambers ranged from $27.2 \pm 0.4{ }^{0} \mathrm{C}$ during the day to $14.2 \pm 0.2{ }^{0} \mathrm{C}$ at night.

\subsection{Chromium (CrIII)}

Inorganic chromium chloride hexahydrate $\left(\mathrm{CrCl}_{3} \cdot 6 \mathrm{H}_{2} \mathrm{O}\right.$; CAS: 10060-12-5; purchased from Sigma-Aldrich Canada Co, Oakville, Ontario) was used as a source of trivalent chromium in the concentration-response toxicity experiments due to its high solubility in water and $>98 \%$ purity. Concentrations used included a control (no chromium added), 250, 500 and $1000 \mathrm{mg} \mathrm{Cr} \mathrm{kg}^{-1}$ soil. These concentrations were selected based on previously reported toxicity tests (Abreu et al., 2002; Bluskov et al., 
2005 and references therein; Lopez-Luna et al., 2009), as well as on levels of chromium found in the environment, which vary greatly in uncontaminated natural soil from $10-$ $100 \mathrm{mg} \mathrm{kg}^{-1}$ (McKeague \& Wolynetz, 1980) to over $5000 \mathrm{mg} \mathrm{kg}^{-1}$ near industrial and mining sites (Pawlisz et al., 1997). Preliminary tests revealed that $1000 \mathrm{mg} \mathrm{kg}^{-1}$ concentration was at the high end of the spectrum without complete mortality. Each concentration was prepared separately by measuring the appropriate amounts of $\mathrm{CrCl}_{3} \cdot 6 \mathrm{H}_{2} \mathrm{O}$ compound and mixing it well with $500 \mathrm{~mL}$ of deionized water. Once thoroughly mixed, $10 \mathrm{~mL}$ of each concentration/replicate was transferred onto soil and distributed evenly with a pipette.

\subsection{Germination study in artificial soil}

\subsubsection{Plant species}

Thirty two plant species were selected representing 18 families with differing ecological characteristics, such as taxonomic group (gymnosperms, angiosperms including monocots and dicots), lifespan (annual, biennial, perennial), status (native and introduced), habitat (upland and wetland) and growth habit (woody, graminoids and forbs) (Table 1). Plant species were also chosen for practical reasons: capacity to purchase seeds from commercial companies and ability to grow within a laboratory environment. Six crop species were chosen to test chromium concentration-response since they are commonly used in toxicity tests. Many seeds from several species do not germinate immediately after being shed and need a stratification period after which they will germinate in the spring rather than in the fall when they would die without 
completing their lifecycle. Thus, tests with pre-stratification contamination were conducted with nine species to determine the effects of chromium during an additional exposure of four to eight week stratification period (Table 1). Optimum stratification durations were chosen based on species germination requirements (White et al., 2009) and according to the directions provided by the seed suppliers.

\subsubsection{Soil preparation}

Artificial soil was used for this experiment and contained $10 \%$ sphagnum peat, $20 \%$ kaolin clay and 70\% silica sand by dry weight (SOP 15.09/1.3/S; Environment Canada, 2005). For a proper homogenization, soil was prepared in small batches (approximately $2.7 \mathrm{~kg}$ ) and the components were thoroughly mixed by a commercial grade electrical mixer (Axis M-20, Axis Equipment, Montreal, Quebec). Two sets of ten batches were prepared: one in October 2013 and a second in May 2014, which were sufficient for the concentration-response experiments. Five hundred millilitres of tap water was added to each batch during mixing to reach $20 \%$ soil moisture content. In addition, due to the natural acidity of sphagnum peat $(\mathrm{pH}=3.10-3.25), 25 \mathrm{~g}$ of calcium carbonate was added to each batch for the first ten prepared batches $(5.85 \pm 0.02)$ and 24 $\mathrm{g}$ for the other ten batches $(5.70 \pm 0.02)$ to increase $\mathrm{pH}$ levels. An IQ150 $\mathrm{pH} / \mathrm{mV} /$ temperature meter (Spectrum Technologies Inc., Plainifield, Illinois) was used to measure soil $\mathrm{pH}$. The prepared $\mathrm{pH}$-adjusted artificial soil was left to settle for at least 48 hrs prior to the experiment and further stored in the dark at $20 \pm 2{ }^{0} \mathrm{C}$. 


\subsubsection{Experimental setup}

Seeds were surface sown in extra-deep disposable Petri dishes (dimensions: $10 \mathrm{x}$ $2 \mathrm{~cm} ; 157 \mathrm{~cm}^{3}$ ), which were filled with $50 \mathrm{~g}$ of artificial soil. Seeds were sown at the soil surface because they need light to promote germination, especially seeds from wild plants. Five independent replicates per concentration were used for a total of 20 Petri dishes per plant species. For any given species, 25 seeds per Petri dish $(n=5)$ and concentration $(n=4)$ for a total of 500 seeds/species were used in the concentrationresponse experiment. Petri dishes with the same chromium concentrations were then placed in trays (dimensions: $28 \times 55 \times 6 \mathrm{~cm}, 10$ dishes/tray) to prevent crosscontamination, and placed in the growth chambers described above. To ensure homogeneity of growing conditions, all trays were rotated clockwise within and between the growth chambers twice a week. Plant species were watered as necessary with deionized water.

To determine if there was a difference in response of nine selected species that underwent stratification prior to germination (Table 1), two separate soil-chromium contaminations were performed. The first involved contaminating the soil with the three CrIII concentrations ( + control) after the plant species went through a four to eight week stratification treatment in a dark refrigerator at $4{ }^{0} \mathrm{C}$. Prior to placing the species in the refrigerator, each Petri dish received $10 \mathrm{~mL}$ of deionized water to maintain soil moisture content. The second contamination was performed prior to placing seeds into the refrigerator as above for stratification. To avoid cross-contamination, possible spillage, and soil moisture loss, each Petri dish was tightly sealed with laboratory parafilm. 


\subsubsection{Data collection}

The average seed weights for each tested species were determined by weighing (Denver Instruments, $\mathrm{P}-403$ balances) a sample containing a range of $20-75$ seeds, depending on the species seed size, then dividing by the total number of weighted seeds.

The number of germinated seedlings was counted every second day for a maximum of 32-34 days. Seeds were considered as successfully germinated when the cotyledons had appeared. Once counted, seedlings were discarded to avoid double counting. Through visual examination, seedlings were divided into two categories: healthy or unhealthy. Unhealthy seedlings were distinguished by reduced root length and hypocotyl height, light discoloration on the cotyledons (early stages of chlorosis), visible wrinkles, wilting and/or early stages of rotting.

\subsection{Seed bank study}

\subsubsection{Study area and site characteristics}

The study area was Nibinamik traditional/reserve land (latitude $52^{0} 47^{\prime} \mathrm{N}$ and longitude $88^{0} 27^{\prime} \mathrm{W}$ ), which is located approximately $500 \mathrm{~km}$ northeast of Thunder Bay, Ontario, Canada (Figure 1) and is only accessible by air transportation or winter roads. Although the best time to collect soil samples for a seed bank study is either in the fall when plants disperse their seeds at the end of their growing season or in the early spring when normal stratification has occurred, but fewer species might emerge since seeds tend to fall deeper into the soil due to soil thawing. Therefore, the soil seed bank samples were collected in September at four differing habitat types in an area of $100 \mathrm{~m}^{2}$. The four 
habitats were selected within the boreal forest, in an upland site $\left(52^{0} 39^{\prime} 35^{\prime \prime} \mathrm{N}\right.$ and $\left.88^{\circ} 33^{\prime} 30^{\prime \prime} \mathrm{W}\right)$, along the Bucheski Lake $\left(52^{0} 38^{\prime} 14^{\prime \prime} \mathrm{N}\right.$ and $\left.88^{\circ} 34^{\prime} 8^{\prime \prime} \mathrm{W}\right)$ and Winisk River $\left(52^{\circ} 42^{\prime} 53^{\prime \prime} \mathrm{N}\right.$ and $\left.88^{\circ} 33^{\prime} 41^{\prime \prime} \mathrm{W}\right)$, as well as in a wetland area $\left(52^{\circ} 43^{\prime} 50^{\prime \prime} \mathrm{N}\right.$ and $88^{0} 37^{\prime} 4^{\prime \prime}$ W) (Figure 2). The seed bank soil samples were collected at the riparian zones of Bucheski Lake and Winisk River. Commonly found woody species were Alnus incana (L.) Moench ssp. rugosa (Du Roi) R.T. Clausen (Betulaceae), Picea mariana (Mill.) Britton, Sterns \& Poggenb. (Pinaceae), Salix spp. (Salicaceae), Abies balsamea (L.) Mill. (Pinaceae), Betula spp. (Betulaceae), as well as some Vaccinium spp. (Ericaceae), Arctostaphylos uva-ursi (L.) Spreng. (Ericaceae), Diervilla lonicera Mill. (Caprifoliaceae), Ribes triste Pall. (Grossulariaceae), Rubus pubescens Raf. (Rosaceae) and Cornus canadensis L. (Cornaceae). Typical boreal herbaceous species were Lysimachia terrestris (L.) Britton, Sterns \& Poggenb. (Primulaceae), Lycopus uniflorus Michx. (Lamiaceae), Pyrola asarifolia Michx. (Ericaceae), Linnaea borealis L. (Caprifoliaceae) and Maianthemum canadense Desf. (Asparagaceae) In addition, the wetland site mostly contained sedges (Carex spp.-Cyperaceae), grasses (Poaceae) and rush (Juncus spp.-Juncaceae) species, as well as sphagnum peat and Lycopodium spp (Lycopodiaceae). All four sampled sites ranged from 10 to $20 \mathrm{~km}$ away from the Nibinamik community, and were considered as undisturbed by human activity. In total, 15 samples of seed bank soil were collected by digging around $10 \mathrm{~cm}$ in depth and removing blocks of soil with a trowel in each site for a total of 60 samples/four sites. Samples were always kept in non-transparent bags and placed in a fridge as soon as 
possible during fieldwork. They were placed into a cooler with ice for transportation back to the laboratory of the NWRC, Environment Canada, Ottawa.

\subsubsection{Experimental setup}

In the laboratory, soil samples were thoroughly homogenized by site and large debris (e.g. stones, roots, twigs, and leaves) were removed by manually sifting the soil. Extra-deep disposable Petri dishes (dimensions: $10 \times 2 \mathrm{~cm} ; 157 \mathrm{~cm}^{3}$ ) were filled to the top with subsamples of soil from each site. Petri dishes were used due to the limited amount of soil that could be transported from Nibinamik territory. Altogether, three replicates per concentration were used totalling to 12 Petri dishes per site. Petri dishes with the same chromium levels were then placed in trays (dimensions: $28 \times 55 \times 6 \mathrm{~cm}$ ) to prevent cross-contamination.

As in the germination study with artificial soil described above, it was necessary to imitate the pre-spring conditions to promote seed germination by exposing soil to a minimum one month stratification period. To test for a possible difference of chromium toxicity on seedling emergence, soil was contaminated with three CrIII concentrations (+ controls) before and after stratification in the same manner as mentioned above (see 2.2.3 Experimental setup). A total of 96 Petri dishes were established (4 concentrations x 3 replicates $\times 4$ sites $\times 2$ stratification treatments).

The seedling emergence method (count and removal of seedlings large enough for identification to genus) was used to determine the seed bank composition (Warr et al., 1993). Due to the known high chromium toxicity to humans including carcinogenicity 
(Lukaski, 1999; De Flora, 2000; O’Flaherty et al., 2001), it was necessary to minimize contact with the contaminated soil and seedlings, therefore $500 \mathrm{~mL}$ subsamples of uncontaminated soil per site were prepared to aid in identifying germinated seedlings and for further comparison to seedlings from Petri dishes. Soil was first sifted in the same way as for the concentration-response tests, placed in a large container (dimensions: $6 \mathrm{x}$ $18 \times 14 \mathrm{~cm} ; 1512 \mathrm{~cm}^{3}$ ), watered and cold stratified for one month. In total, 24 subsamples for all four sites were prepared.

All 120 soil samples (Petri dishes and large containers) were placed in the growth chamber mentioned above for six months from late October (21 and 27), 2014 until late April (21 and 27), 2015. Since Petri dishes were filled to the top with soil, the Petri dish lids were removed and instead lids of the large trays were used to maintain soil moisture content. Soil was watered as necessary with deionized water for Petri dishes and tap water for large containers. For homogeneity of growing conditions, all trays were rotated clockwise within the chamber once a week.

Seedlings that could not be promptly identified were transplanted into $10 \mathrm{~cm}$ pots filled with a mixture of promix soil and sand, and grown in the growth chamber until identification was possible. Seedlings from Petri dishes were compared to already identified plants from large containers, counted and removed. Most seeds germinated during the first four months of the experiment. The soil was occasionally stirred in both Petri dishes and large containers to stimulate germination of seeds that need light. 


\subsection{Chemical analyses}

\subsubsection{Chromium analysis}

For the determination of background levels of chromium in the artificial soil and for the validation of calculated nominal concentrations, soil-metal analysis was conducted by the Alberta Innovated Technology Futures (AITF, Vegreville, Alberta) and by the RPC Science and Engineering (RPC, Fredericton, New Brunswick) laboratories. Soil samples used for the total amount of chromium analysis were obtained by pooling all five independent replicates separately for all four concentrations, including controls for each tested plant. For AITF, soil of seven plant species was analyzed using the $\mathrm{HNO}_{3} / \mathrm{HCl}$ digestion method and according to revised EPA Method 200.8; samples were processed in a $60{ }^{0} \mathrm{C}$ oven, sieved for homogeneity, and diluted to $100 \mathrm{~mL}$ with reagent grade water (US EPA, 1994). For RPC, soil samples of twenty five plants were analyzed using the $\mathrm{HNO}_{3} / \mathrm{H}_{2} \mathrm{O}_{2}$ digestion method and according to revised EPA Method 3050B; samples were air dried and sieved for homogeneity, and then diluted to $100 \mathrm{~mL}$ with reagent grade water (US EPA, 1996). In both cases, digestates were further analyzed by inductively coupled plasma-mass spectrometry (ICP-MS). An ANCOVA analysis of the dosed soil in relation to nominal levels (continuous variables) and commercial laboratories (categorical variable) found an effect of nominal concentrations on the measured concentrations ( $\mathrm{p}<\mathbf{0 . 0 0 1}$; as expected), but no effect of laboratories on measured concentrations $(p=0.591)$ and no interaction $(p=0.447)$. 
For the detection of chromium baseline levels in the soil seed bank samples, soilmetal analysis with soil from four sampled sites separately was also performed by the RPC Science and Engineering laboratory (RPC, Fredericton, New Brunswick) following the revised EPA Method 3050B (US EPA, 1996).

\subsubsection{Other metals analyses}

For the determination of background levels of twenty seven other trace and heavy metals in the artificial and seed bank soils, soil-metal analyses were conducted by the RPC Science and Engineering laboratory. In total, twenty five control artificial soil samples and four control seed bank soil samples were analyzed. Trace metal amounts in soil were either analyzed by inductively coupled plasma-mass spectrometry (ICP-MS) according to revised EPA Method 200.8 (US EPA, 1994) or by inductively coupled plasma-atomic emission spectrometry (ICP-ES) following revised EPA Method 200.7 (US EPA, 1994), depending on the metal analyzed. Mercury content in soil was analyzed by cold vapor atomic absorption spectrophotometry (AAS) according to revised EPA Method 245.5 (US EPA, 2001).

\subsubsection{Analyses of physicochemical soil constituents}

The average cationic exchange capacity (CEC) of six randomly selected artificial

soil samples was found to be $16.82 \pm 2.65$ meg $100 \mathrm{~g}^{-1}$ (completed by Agriculture and Food Laboratory Services, University of Guelph, Guelph, Ontario) using the barium ammonium method (Rhoades, 1982). The soil organic matter content was $12.16 \pm 0.76 \%$ 
based on the loss on ignition weight. Soil samples were placed in the Barnstead/Thermolyne F62735 furnace for 1300 minutes at $350{ }^{\circ} \mathrm{C}$.

Soil that was not used during the concentration-response experiment and for the seed bank composition was analyzed by the Agriculture and Food Laboratory Services for various physicochemical soil attributes, including soil texture ( $\%$ gravel, $\%$ sand, $\%$ silt, \% clay), total carbon ( $\%$ inorganic and $\%$ organic carbon), $\mathrm{CEC}, \mathrm{pH}$, organic matter and moisture contents, and levels of ammonium, nitrate and phosphorus, which are all significant factors for plant and microbial growth, as well as mobility and bioavailability of chromium. Since the soil organic matter contains a significant portion of organic carbon derived from non-decomposed plant and animal remains, it can be calculated either via loss on ignition weight or by multiplying the organic carbon content by a constant factor of 1.72 (EPS 1/RM/56; Environment Canada, 2013). Organic carbon content was estimated using the potassium dichromate/sulphuric acid method (Tiessen \& Moir, 1993). The level of ammonium in the soil was determined using alkaline phenol and hypochlorite and according to procedures outlined in EPA Method 350.1 (US EPA, 1983). The level of nitrate in soil was estimated by the reaction with copperized cadmium and according to the further procedure outlined in EPA Method 353.2 (US EPA, 1993). Phosphorus concentration in the soil was estimated using the sodium bicarbonate method (Reid, 1998). Soil particle size distribution analysis was conducted according to the principle of sedimentation by Stoke's Law (Sheldrick \& Wang, 1993) to determine soil texture. 


\subsection{Calculations and statistical analyses}

Statistical analyses with proportion data collected from the germination study in artificial soil were performed using SAS version 9.3 (SAS Institute Inc., Cary, North Carolina) and according to Organization of Economic Co-Operation and Development ecotoxicity guidelines (OECD, 2006). All statistics with count data collected from the seed bank study were performed using SPSS version 22.0 (IBM Corp., Armonk, New York) and Systat version 13.00.05 2009 (Systat Software Inc., Chicago, Illinois). All results are reported as significant at $\mathrm{p}<0.05$.

Gleason and Cronquist (1991) and Oldham et al. (1995) were used to divide plants into either their suitable wetland or upland habitat prior to the statistical analyses. Woody species were defined as both trees and shrubs/subshrubs.

\subsubsection{Germination study in artificial soil}

Upon completion of the experiment, percent germination $(\% \mathrm{G})$ was calculated using the ratio of the number of emerged seedlings/Petri dish to the total number of seeds sowed. Additionally, speed of germination (SG), a measure of how quickly seeds germinate over the test period, was calculated based on the following formula $\sum\left(\mathrm{N}_{1} / 1+\mathrm{N}_{2} / 2+\mathrm{N}_{3} / 3+\ldots . .+\mathrm{N}_{i} / i\right)$ (adjusted from Allaie et al., 2006), where $\mathrm{N}_{1}$ is number of seeds germinated on day $1, \mathrm{~N}_{2}$ is number of seeds germinated on day 2 , etc. and $\mathrm{N}_{i}$ is the number of seeds germinated on day $i$. SG was calculated by taking into account the total number of germinated seeds for each species (and was not calculated for healthy seedlings). 
The Mantel-Haenszel analysis under the PROC FREQ procedure was used to: (1) test for the difference in responses, germination and health, amongst tested plants with diverse taxonomic/ecological characteristics, and (2) test for differences between stratified and non-stratified plants. To test for a concentration-response to chromium for binary measures of germination (germinated/not germinated) and health (healthy/unhealthy) with data exhibiting monotonic response by visual inspection, the Cochran-Armitage trend test was applied under the same procedure. The pairwise Fisher's exact test was conducted comparing each treatment to controls. Additionally, either one-way ANOVA (PROC GLM) or the non-parametric Kruskal-Wallis (PROC NPAR1WAY) tests were used to evaluate if chromium had an effect on species speed of germination. The non-parametric test was conducted when the assumptions (i.e. normality and variance homogeneity) were not met. Once the overall significant effect of all treatments was found, the parametric (Dunnett's test) or the non-parametric (Savage test) pairwise comparisons to the controls were conducted.

Concentration-response modeling was performed following the PROC PROBIT procedure to estimate the effective chromium concentrations (EC10, EC25, EC50) causing $10 \%, 25 \%$ and $50 \%$ reduction in species germination. In cases of non-monotonic response, EC values were calculated using the non-parametric interpolation method done in ICPIN program (Norberg-King, 1993). Linear regression analyses were used to: (1) test for a relation between the expected (nominal) and measured levels of chromium in dosed artificial soil and (2) test for a relation between the tested species seed sizes and estimated EC25s. 


\subsubsection{Seed bank study}

The total number of seedlings and species emerged in Petri dishes was used to assess the effects of chromium on the seed bank. Poisson regression under the Generalized Linear Model framework was conducted to: (1) determine the effects of chromium concentrations, (2) assess the effects of exposure before and after the stratification treatment, and (3) test for differences in seedling emergence for species with differing taxonomic/ecological characteristics (i.e. monocot and dicot groups, wetland and upland habitats, and woody, graminoid or forb habits). 
Table 1: Characteristics of 32 plant species from 18 botanical families tested in the chromium (CrIII) concentration-response experiment in artificial soil. Species scientific names were obtained from the USDA Plants Database (http://www.plants.usda.gov/java/) and from the Database of Vascular Plants of Canada (VASCAN) (http://data.canadensys.net/vascan/search). Species are separated into gymnosperms and angiosperms, as well as into monocots and dicots. Dicots are further separated into woody (i.e. trees and shrubs), herbaceous non-crops and crops. Lifespan is represented as annual (A), biennial (B) and perennial (P) (http://www.plants.usda.gov/java/). Habitat was divided into several categories, as follows: OBL (obligate wetland) - plant species almost always found in wetlands under natural conditions ( $>$ 90\% probability), FACW (facultative wetland) - usually found in wetlands, but occasionally found in non-wetlands (67-89\%), FAC (facultative) - equally likely to occur in wetlands or non-wetlands (34-66\%), FACU (facultative upland) - occasionally occurs in wetlands, but usually found in non-wetlands (1-33\%), and UPL (obligate upland) - almost never found in wetlands under natural conditions (<1\%), and status was divided to either $\mathrm{N}=$ Native or I = Introduced (Oldham et al., 1995). N status means that plant species are native to Ontario. The seeds of tested plants were purchased from commercial suppliers and grown within the laboratory environment in artificial soil. Stratification for nine species occurred in a dark refrigerator at $4{ }^{0} \mathrm{C}$. Average $\%$ germination was calculated from seeds germinating in the controls; * represents the $\%$ germination of stratified seeds. STD error stands for standard error.

\begin{tabular}{|c|c|c|c|c|c|c|c|c|c|}
\hline Scientific name & Common name & Family & Lifespan & Habitat & Status & $\begin{array}{l}\text { Stratification } \\
\text { (weeks) }\end{array}$ & $\begin{array}{l}\text { Average } \\
\text { seed } \\
\text { weight } \\
\text { (mg) }\end{array}$ & $\begin{array}{c}\text { Average } \\
\text { Germination } \\
(\%)\end{array}$ & $\begin{array}{l}\text { STD } \\
\text { error } \\
(\%)\end{array}$ \\
\hline \multicolumn{10}{|c|}{ Gymnosperms } \\
\hline $\begin{array}{l}\text { Abies balsamea } \\
\text { (L.) Mill. (3) }\end{array}$ & Balsam fir & Pinaceae & $\mathrm{P}$ & FACW & $\mathrm{N}$ & 6 & 8.0 & $\begin{array}{c}64.0 \\
54.4^{*}\end{array}$ & $\begin{array}{l}2.8 \\
5.0\end{array}$ \\
\hline \multirow{2}{*}{$\begin{array}{l}\text { Picea mariana } \\
\text { (Mill.) Britton, } \\
\text { Sterns \& Poggenb. }\end{array}$} & Black spruce & Pinaceae & $\mathrm{P}$ & FACW & $\mathrm{N}$ & 6 & 1.2 & 78.4 & 5.0 \\
\hline & & & & & & & & $85.6^{*}$ & 2.7 \\
\hline
\end{tabular}




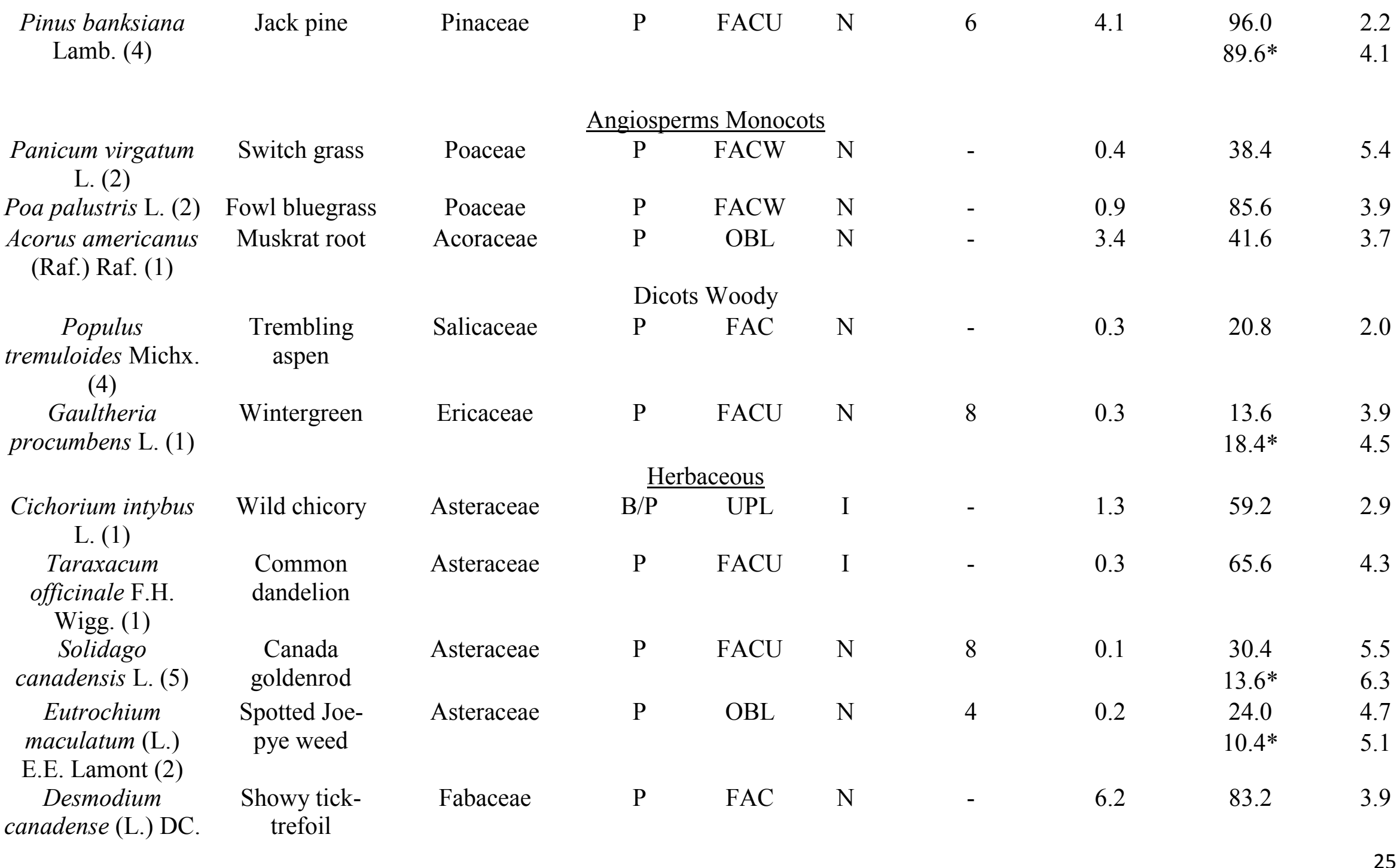


(3)

\begin{tabular}{|c|c|c|c|c|c|c|c|c|c|}
\hline $\begin{array}{c}\text { Nepeta cataria L. } \\
\text { (1) }\end{array}$ & Catnip & Lamiaceae & $\mathrm{P}$ & FAC & I & - & 0.6 & 41.6 & 4.3 \\
\hline $\begin{array}{l}\text { Salvia officinalis L. } \\
\text { (1) }\end{array}$ & Garden sage & Lamiaceae & $\mathrm{P}$ & UPL & $\mathrm{I}$ & - & 7.1 & 83.2 & 3.5 \\
\hline $\begin{array}{l}\text { Chenopodium } \\
\text { album L. (1) }\end{array}$ & $\begin{array}{l}\text { Lamb's } \\
\text { quarters }\end{array}$ & Chenopodiaceae & A & FAC & I & - & 0.1 & 10.4 & 1.8 \\
\hline $\begin{array}{c}\text { Asclepias syriaca } \\
\text { L. (1) }\end{array}$ & $\begin{array}{l}\text { Common } \\
\text { milkweed }\end{array}$ & Asclepiadaceae & $\mathrm{P}$ & UPL & $\mathrm{N}$ & 4 & 6.5 & $\begin{array}{c}75.2 \\
70.4^{*}\end{array}$ & $\begin{array}{l}3.1 \\
4.7\end{array}$ \\
\hline $\begin{array}{c}\text { Hypericum } \\
\text { perforatum L. (1) }\end{array}$ & $\begin{array}{l}\text { Common St. } \\
\text { John's wort }\end{array}$ & Clusiaceae & $\mathrm{P}$ & UPL & $\mathrm{I}$ & 4 & 0.4 & $\begin{array}{c}34.4 \\
49.6 *\end{array}$ & $\begin{array}{l}1.4 \\
6.8\end{array}$ \\
\hline $\begin{array}{c}\text { Hibiscus } \\
\text { moscheutos L. (2) }\end{array}$ & $\begin{array}{l}\text { Swamp rose } \\
\text { mallow }\end{array}$ & Malvaceae & $\mathrm{A} / \mathrm{P}$ & OBL & $\mathrm{N}$ & - & 7.2 & 53.6 & 6.8 \\
\hline Alcea rosea L. (1) & Hollyhock & Malvaceae & $\mathrm{B} / \mathrm{P}$ & UPL & I & - & 10.1 & 45.6 & 3.9 \\
\hline $\begin{array}{l}\text { Ipomoea purpurea } \\
\text { (L.) Roth (3) }\end{array}$ & Morning glory & Convolvulaceae & $\mathrm{A}$ & FACU & I & - & 33.2 & 96.0 & 1.1 \\
\hline $\begin{array}{c}\text { Raphanus sativus } \\
\text { L. (1) }\end{array}$ & $\begin{array}{l}\text { Cultivated } \\
\text { radish }\end{array}$ & Brassicaceae & $\frac{\text { Herb }}{A / B}$ & $\frac{\text { us Crops }}{\text { UPL }}$ & $\mathrm{I}$ & - & 8.6 & 97.6 & 1.4 \\
\hline
\end{tabular}




\begin{tabular}{|c|c|c|c|c|c|c|c|c|c|}
\hline $\begin{array}{c}\text { Solanum } \\
\text { lycopersicum L. (1) }\end{array}$ & Garden tomato & Solanaceae & $\mathrm{A} / \mathrm{P}$ & UPL & I & - & 1.7 & 86.4 & 5.5 \\
\hline Medicago sativa L. & Alfalfa & Fabaceae & $\mathrm{A} / \mathrm{P}$ & UPL & I & - & 2.0 & 80.0 & 2.8 \\
\hline $\begin{array}{c}\text { Trifolium pratense } \\
\text { L. (1) }\end{array}$ & Red clover & Fabaceae & $\mathrm{B} / \mathrm{P}$ & FACU & I & - & 1.8 & 94.4 & 2.1 \\
\hline $\begin{array}{l}\text { Brassica juncea } \\
\text { (L.) Czern. (1) }\end{array}$ & $\begin{array}{l}\text { Indian/Brown } \\
\text { mustard }\end{array}$ & Brassicaceae & $\mathrm{A} / \mathrm{B}$ & UPL & I & - & 3.1 & 67.2 & 2.1 \\
\hline $\begin{array}{l}\text { Nasturtium } \\
\text { officinale W.T. } \\
\text { Aiton (1) }\end{array}$ & Watercress & Brassicaceae & $\mathrm{P}$ & $\mathrm{OBL}$ & I & - & 0.1 & 72.8 & 5.8 \\
\hline
\end{tabular}

1-Richters Herb (357 Highway 47, Goodwood, ON, Canada, L0C 1A0; 1-905-640-6677 (tel.), 1-905-640-6641 (fax))

2-Prairie Moon Nursery (32115 Prairie Lane, Winoma, MN, USA, 55987; 866-417-8156 (toll free), 507-452-1362 (tel.), 507-454-5238 (fax))

3-OSC Seeds (16 King St. Waterloo, ON, Canada; 519-886-2990)

4-Sheffield's Seeds Co., Inc. (269 Auburn Rd, Route 34, Locke, New York, USA, 13092; 315-497-1058 (tel.), 315-497-1059 (fax))

5-Wild About Flowers (Box 22, Site 15, RR1, Okotoks, AB, Canada, T1S-1A1; 403-933-3903) 


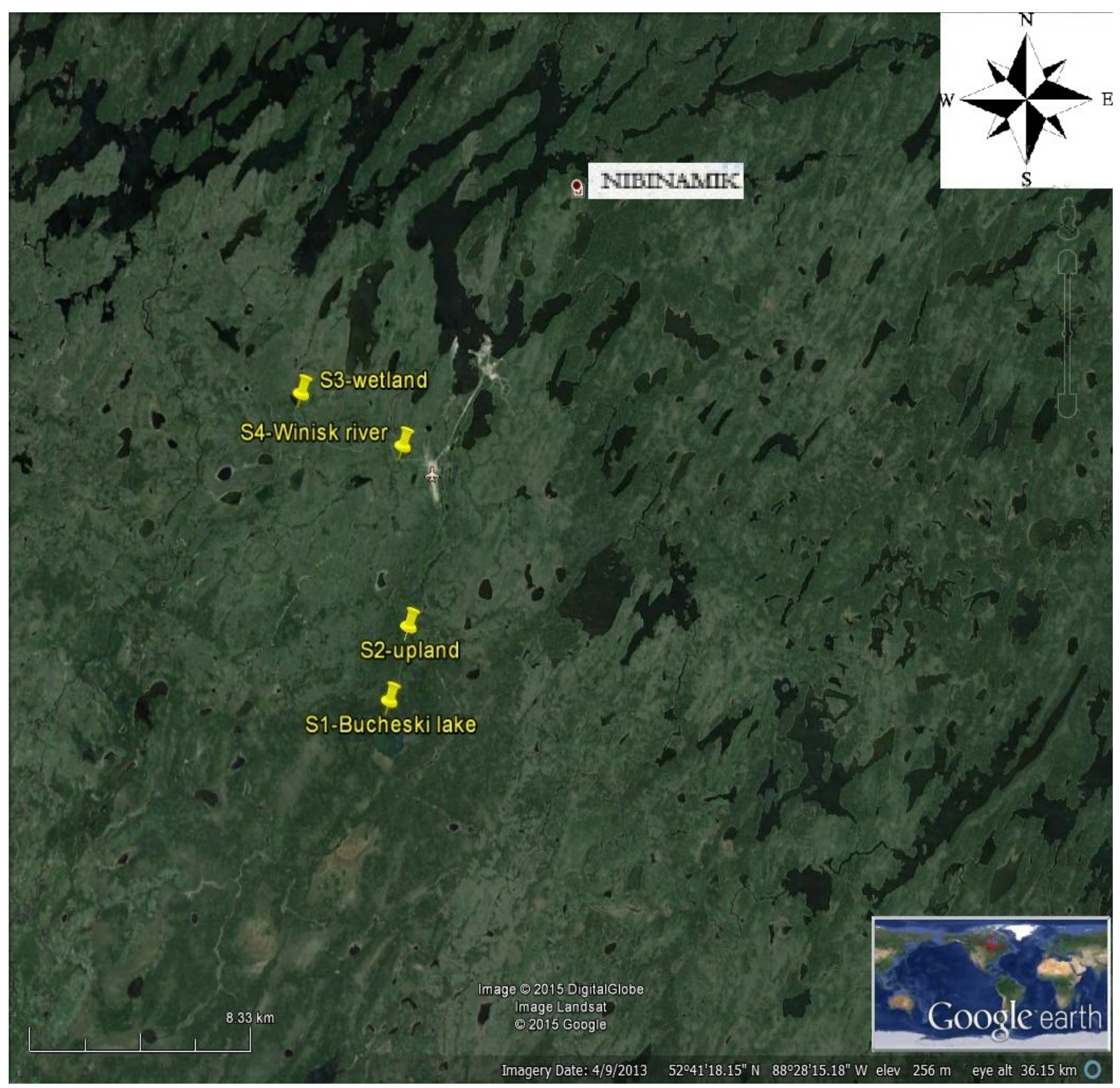

Figure 2: Map showing the four study sites (S1-Bucheski Lake, S2-Upland, S3-Wetland, and S4-Winisk River) located in Nibinamik (in Oji Cree - Summer Beaver in English translation) First Nations traditional/reserve land, Ontario, Canada and where soils were collected during field work (September 11 and 12, 2014). 


\section{Chapter 3: Results}

\subsection{Soil conditions}

The measured levels of chromium in dosed artificial soil were slightly higher than the expected (nominal) levels except at the highest concentration (Figure 3), but a significant positive trend was found $\left(\mathrm{R}^{2}=0.898, \mathrm{~F}_{1,121}=1064.903, \mathrm{p}<\mathbf{0 . 0 0 1}\right.$; measured levels). The background chromium levels in the control artificial soil were found to be much lower than the chromium levels naturally found in soil (Appendix 1). In addition, levels of 20 of the 27 trace metals in the artificial soil were below detectable levels, and levels of seven other metals (i.e. arsenic, lead, selenium, silver, tellurium, tin and uranium) were slightly higher than minimum natural levels, but none higher than maximum natural levels (Appendix 1). Therefore, no effect of other metals besides chromium was expected.

In the soils from the lake, upland and river sites, the level of chromium was above the minimum but less than the maximum level found naturally in soil (Appendix 2). Some trace elements also fell between their natural minimum and maximum levels in soil, including nine metals found in the soil from the lake site, ten metals from the upland site, six metals from the soil belonging to the wetland site, and ten from the river site (Appendix 2). The level of manganese from the river soil was higher than the maximum natural level (Appendix 2). Additionally, the level of arsenic from the river soil and the boron levels from wetland and river soils were higher than the recommended Canadian soil quality guidelines (Appendix 2). 
Soils collected for the seed bank study differed amongst sites for most attributes (Table 2). The $\mathrm{pH}$ was lowest in the upland soil and highest in the wetland soil. The soil from the wetland site was exceptionally rich in nutrients, but low in nitrate, and contained high soil organic matter with associated high CEC as compared to the rest of the sampled sites (Table 2). The texture of the soil from both the lake and upland sites was loamy coarse, while the soil was clay loam and pure peat in the river and wetland sites, respectively (Table 2).

\subsection{Effects of chromium (CrIII) on plants in artificial soil}

Substantial effects of chromium on the germination and health of the tested plant species were observed with increasing concentrations (Figure 4). Many tested species were not significantly affected by chromium at the lowest concentration $\left(250 \mathrm{mg} \mathrm{kg}^{-1}\right)$, but the highest concentration $\left(1000 \mathrm{mg} \mathrm{kg}^{-1}\right)$ caused low germination for almost all tested species (Figure 4), with the exception of Populus tremuloides Michx. (Salicaceae) $\left(20.8 \%, 26.4 \%, 20.0 \%\right.$ and $12.8 \%$ germination at control, 250,500 and $1000 \mathrm{mg} \mathrm{kg}^{-1}$ treatments respectively) and Hypericum perforatum L. (Clusiaceae) $(34.4 \%, 36.0 \%$, $32.8 \%, 28.8 \%$ ) (Appendices 3 and 4). At the highest chromium concentration, a significant effect on health of all 32 plants treated with chromium without stratification was found (Figure 4). Incomplete germination at the highest (1000 $\mathrm{mg} \mathrm{kg}^{-1}$ ) concentration was observed for the following species: Asclepias syriaca L. (Asclepiadaceae), Solanum lycopersicum L. (Solanaceae), Brassica juncea (L.) Czern. (Brassicaceae), R. sativus, Trifolium pratense L. (Fabaceae), S. officinalis, Medicago sativa L. (Fabaceae), Ipomoea purpurea (L.) Roth (Convolvulaceae), Gaultheria 
procumbens L. (Ericaceae), Desmodium canadense (L.) DC (Fabaceae)., P. mariana, Pinus banksiana Lamb. (Pinaceae), P. tremuloides, and Eutrochium maculatum (L.) E.E. Lamont (Asteraceae). In these cases, the seed coats were ruptured by the emerged radicle, but further germination was inhibited. However, since germination was only counted when open cotyledons were visible, incomplete germination was not considered during the statistical analyses.

Chromium had a negative effect on speed of germination of almost all tested plants, except for $H$. perforatum. Though an overall significant effect of chromium concentration on $H$. perforatum was detected in the one-way analysis of variance, no chromium concentrations were found to be statistically different from the controls according to a Dunnett's test (Figure 4; Appendix 5). The lowest observed effect (lowest chromium concentration with statistically significant effect) on speed of germination of 32 plant species treated with CrIII during the concentration-response experiment varied with 13 cases at $250 \mathrm{mg} \mathrm{kg}^{-1}, 12$ cases at $500 \mathrm{mg} \mathrm{kg}^{-1}$, six cases at $1000 \mathrm{mg} \mathrm{kg}^{-1}$ (Appendix 5).

Nine plant species were tested with added chromium levels during the stratification period (Figure 5). A significant difference in responses for all five forbs and four woody species was found; plant species exposed to chromium only during the concentration-response experiment appeared to be more tolerant than when they were also exposed to chromium during the stratification period (Table 3). Six of the tested species were sensitive to chromium even at the lowest concentration when they were exposed during stratification in addition to the concentration-response experiment (Figure 
5); only P. mariana ( $85.6 \%$ germination at control and $83.2 \%$ at $\left.250 \mathrm{mg} \mathrm{kg}^{-1}\right), P$. banksiana (89.6\% and 91.2\%) and Solidago canadensis L. (Asteraceae) (13.6\% and 26.4\%) were less sensitive (Appendices 3 and 4). At $500 \mathrm{mg} \mathrm{kg}^{-1}$ of chromium in soil, $S$. canadensis (13.6\% and $12.0 \%)$ and P. banksiana (89.6\% and $84.0 \%)$ were also tolerant to chromium, with the latter experiencing relatively high germination but poor health (Figure 5; Appendices 3 and 4). At $1000 \mathrm{mg} \mathrm{kg}^{-1}$ of chromium in soil, a significant effect was found for germination of almost all species except for $S$. canadensis $(13.6 \%$ and 7.2\%), although all the tested species were unhealthy (Figure 5; Appendices 3 and 4).

Chromium had a negative effect on speed of germination of almost all nine species exposed to chromium over the long-term (i.e. with stratification), except Verbena hastata L. (Verbenaceae) and E. maculatum (Figure 5; Appendix 5). The lowest observed effect was found for six species at $250 \mathrm{mg} \mathrm{kg}^{-1}$ concentration and only for S. canadensis at $500 \mathrm{mg} \mathrm{kg}^{-1}$ (Appendix 5).

The proportion of germinated seeds and healthy seedlings belonging to dicots was much higher amongst chromium treatments compared to the monocots, showing that monocots were more sensitive (Table 4). Also, the wetland plant species were more sensitive to chromium than the upland species at all tested chromium concentrations (Table 4). Variability in germination and health of native and introduced species was observed with increasing chromium levels in soil (Table 4). Interestingly, crops were the most tolerant to chromium toxicity compared to the rest of the tested plant species (Table 4). As for the growth habit, woody species were more tolerant than forbs and graminoids to chromium, especially at the highest concentration (Table 4). 
The measured chromium levels in soil were used to estimate the effective chromium concentrations (EC10, EC25, and EC50) causing 10\%, 25\%, and 50\% reduction in plant species germination in relation to the controls (Appendix 6). Species sensitivity ranks to chromium toxicity were graphed based on the estimated EC25 for 28 plant species tested without stratification and eight plant species with stratification, including nine native herbs, four native woody species, eleven introduced forbs and six crops (Figure 6). The EC25 could not be calculated in four cases since no concentrationresponse effect was detected (Appendix 6). The non-stratified P. banksiana $(96.0 \%$, $93.6 \%, 92.8 \%$, and $76.0 \%$ germination at control, 250,500 and $1000 \mathrm{mg} \mathrm{kg}^{-1}$ treatments respectively) (Appendix 3) proved to be tolerant to chromium with EC25 exceeding the maximum concentrations tested (Appendix 6). M. arvensis (48.0\%, 12.8\% 1.6\%, 0\%), Acorus americanus (Raf.) Raf. (Acoraceae) (41.6\%, 20.8\%, 14.4\%, 5.6\%), and Urtica dioica L. (Urticaceae) $(16.0 \%, 6.4 \%, 4.0 \%, 0.8 \%)$ (Appendix 3) were very sensitive to chromium even at the natural levels in soil $\left(<250 \mathrm{mg} \mathrm{kg}^{-1}\right)$ (Figure 6). Likewise, $H$. perforatum $(49.6 \%, 11.2 \%, 4.8 \%, 3.2 \%)$, E. maculatum $(10.4 \%, 2.4 \%, 4.0 \%, 0.8 \%), G$. procumbens $(18.4 \%, 6.4 \%, 1.6 \%, 0 \%)$ and $V$. hastata $(15.2 \%, 2.4 \%, 2.4 \%, 0.8 \%)$ (Appendix 3) displayed high sensitivity to chromium when they were exposed over the long-term period (i.e. with stratification) (Figure 6). I. purpurea $(96.0 \%, 92.0 \%, 84.8 \%$, 69.6\%), D. canadense $(83.2 \%, 78.4 \%, 79.2 \%, 38.4 \%)$ and Rumex acetosa L. (Polygonaceae) $(76.8 \%, 82.4 \%, 67.2 \%, 38.4 \%)$ (Appendix 3) were very tolerant to chromium compared to other tested species (Figure 6). No one family displayed more or less sensitivity with the exception of the Lamiaceae and Asteraceae (excluding the 
tolerant $S$. canadensis) families where species seemed more affected by chromium. Seed size may be considered when evaluating toxicity of chromium; a significant positive trend was found between the increasing tested plant seed sizes and the estimated EC25 $\left(\mathrm{R}^{2}=0.1504 ; \mathrm{F}_{1,27}=4.781 ; \mathrm{p}=\mathbf{0 . 0 3 8}\right)($ Figure 7$)$.

\subsection{Effects of chromium (CrIII) on plants from the seed bank}

Overall, 38 native plant species from 20 botanical families emerged during the experiment from October, 2014 to April, 2015 from the seed bank soils (large containers and Petri dishes together) with the most common being from the Rosaceae and Ericaceae families (Table 5). More species and seedlings emerged from the large containers compared to the Petri dishes due to the latter containing almost ten times less soil. In total, 21 plant species from 15 families emerged in Petri dishes (15 species from 12 families when soil was contaminated without stratification with additional six species when soil was contaminated with stratification) (Table 5; Appendices 7-10).

A significant effect of chromium concentrations was found in the habitat situated near Bucheski Lake with a reduction in the number of seedlings as concentration of chromium increased (Figure 8; Table 6). This negative trend was similar for the upland habitat (Figure 9; Table 6). On the contrary, no significant chromium effect was found for the seeds from the river and wetland habitats (Figures 10 and 11; Table 6). Interestingly, no significant difference for seeds and seedlings was found between the stratification condition and chromium concentrations for all four habitats (Table 6). 
Though we found overall low levels of germination in the chromium seed bank experiment, some simple, if preliminary, trends were still observed. Several native plant species, including Calamagrostis canadensis (Michx.) P. Beauv. (Poaceae), Potentilla norvegica L (Rosaceae), and D. lonicera were not as sensitive to the highest level (1000 $\mathrm{mg} \mathrm{kg}^{-1}$ ) of chromium in the lake soil than the other species grown in the same soil, as well as they were not as much affected by the long-term chromium exposure (i.e. with stratification) (Appendix 7). L. uniflorus and S. canadensis also tolerated the $500 \mathrm{mg} \mathrm{kg}^{-1}$ chromium concentration (Appendix 7). A. americanus emerged in $250 \mathrm{mg} \mathrm{kg}^{-1}$ chromium concentration, but not in the soil that contained higher $\left(>500 \mathrm{mg} \mathrm{kg}^{-1}\right)$ levels of chromium (Appendix 7), as was observed in the concentration-response experiment in artificial soils. Vaccinium angustifolium Aiton (Ericaceae) was sensitive to higher chromium levels $\left(>250 \mathrm{mg} \mathrm{kg}^{-1}\right)$ when grown in soil contaminated with chromium before stratification, but was more tolerant $\left(>500 \mathrm{mg} \mathrm{kg}^{-1}\right)$ when grown in soil spiked with chromium after stratification (Appendix 7). In addition, Symphyotrichum cordifolium (L.) G.L. Nesom (Asteraceae) grew in soil contaminated with $500 \mathrm{mg} \mathrm{kg}^{-1}$ of chromium (Appendix 10). Betula papyrifera Marshall (Betulaceae) was not sensitive to chromium when soil was treated with chromium after stratification (Appendix 8). The wetland woody plant species, Vaccinium oxycoccos L. (Ericaceae), was relatively tolerant to chromium in high levels (>1000 $\mathrm{mg} \mathrm{kg}^{-1}$ ) in soil (Appendix 9). A larger scale study would be required to determine if these trends are consistent across other seed banks.

It was important to investigate the effects of chromium on plant species with differing taxonomic/ecological characteristics. Because the overall sample size was 
relatively small for all sites except the lake site, all seedlings that emerged during the concentration-response experiment from all four sampled sites were pooled. The proportion of emerged seedlings belonging to monocots was higher than for dicots amongst all chromium treatments (Wald Chi-square: 15.312; df: 1; p < 0.001). Interestingly, no effect was found between the wetland and upland plant species $(0.418$; $1 ; 0.518)$. Graminoids were more tolerant than forbs $(17.570 ; 1 ;<\mathbf{0 . 0 0 1})$ or woody species $(9.489 ; 1 ;<\mathbf{0 . 0 0 1})$ to chromium. 


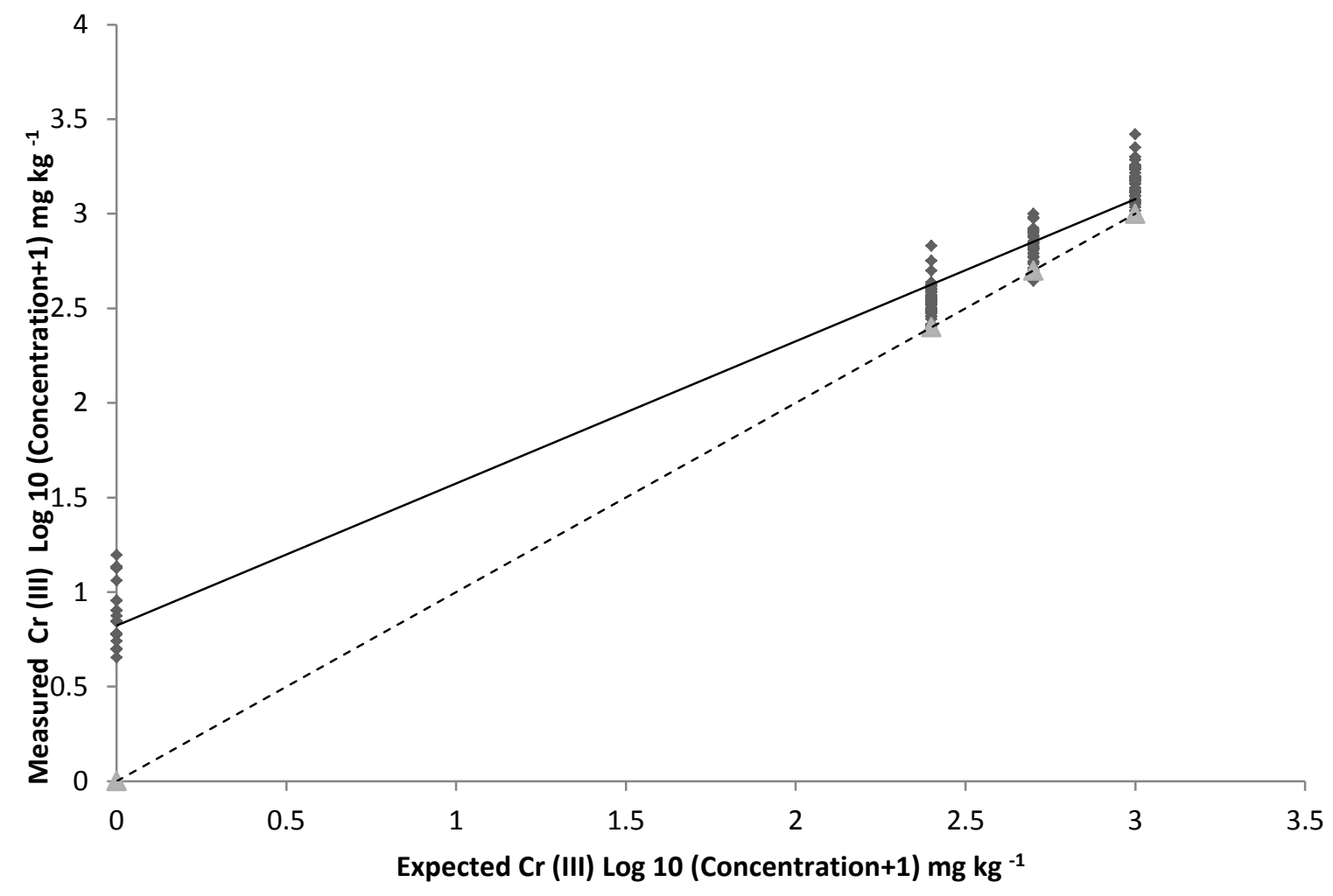

Figure 3: Levels of chromium in prepared artificial soil during the concentrationresponse experiment. Following completion of the experiment, soil samples of all five independent replicates were pooled separately for all four concentrations, including controls for each tested plant. The measured chromium levels [solid line] in soil samples were slightly higher than the nominal levels [dashed line]. The Determination Coefficient for the measured concentrations $\left(\mathrm{R}^{2}=0.898\right)$ shows that all points accurately fit the statistical model with minimum variability. 
Table 2: Soil attributes of four sampled sites including lake, upland, wetland and river located in Nibinamik traditional/reserve land, Northern Ontario, Canada.

\begin{tabular}{|c|c|c|c|c|}
\hline \multirow[b]{2}{*}{ Soil attributes } & \multicolumn{4}{|c|}{ Sampled Habitats } \\
\hline & Lake & Upland & Wetland & River \\
\hline $\mathrm{pH}$ & 6.9 & 5.1 & 7.3 & 6.5 \\
\hline CEC (meg 100 ${ }^{-1}$ ) & 15.9 & 7.1 & 137.0 & 60.8 \\
\hline Organic matter $(\%)$ & 13.8 & 6.4 & 81.2 & 26.0 \\
\hline Texture & loamy coarse & loamy coarse & pure peat & clay loam \\
\hline Gravel (\%) & 4.3 & 3.2 & - & 0.0 \\
\hline Sand $(\%)$ & 86.1 & 83.5 & - & 21.6 \\
\hline Silt (\%) & 6.1 & 11.5 & - & 48.6 \\
\hline Clay $(\%)$ & 7.8 & 4.9 & - & 29.8 \\
\hline Total Carbon (\%) & 8.5 & 3.7 & 47.8 & 15.3 \\
\hline Organic Carbon $(\%)$ & 8.0 & 3.7 & 47.1 & 15.1 \\
\hline Inorganic Carbon (\%) & 0.5 & 0.0 & 0.7 & 0.2 \\
\hline Soil Moisture (\%) & 41.5 & 19.7 & 1484.0 & 106.8 \\
\hline Ammonium $\left(\mathrm{mg} \mathrm{kg}^{-1}\right)$ & 2.9 & 6.1 & 42.2 & 3.8 \\
\hline Nitrate $\left(\mathrm{mg} \mathrm{kg}^{-1}\right)$ & 79.4 & 13.1 & 10.7 & 97.9 \\
\hline Phosphorus (mg kg ${ }^{-1}$ ) & 5.4 & 10.2 & 64.0 & 10.6 \\
\hline
\end{tabular}




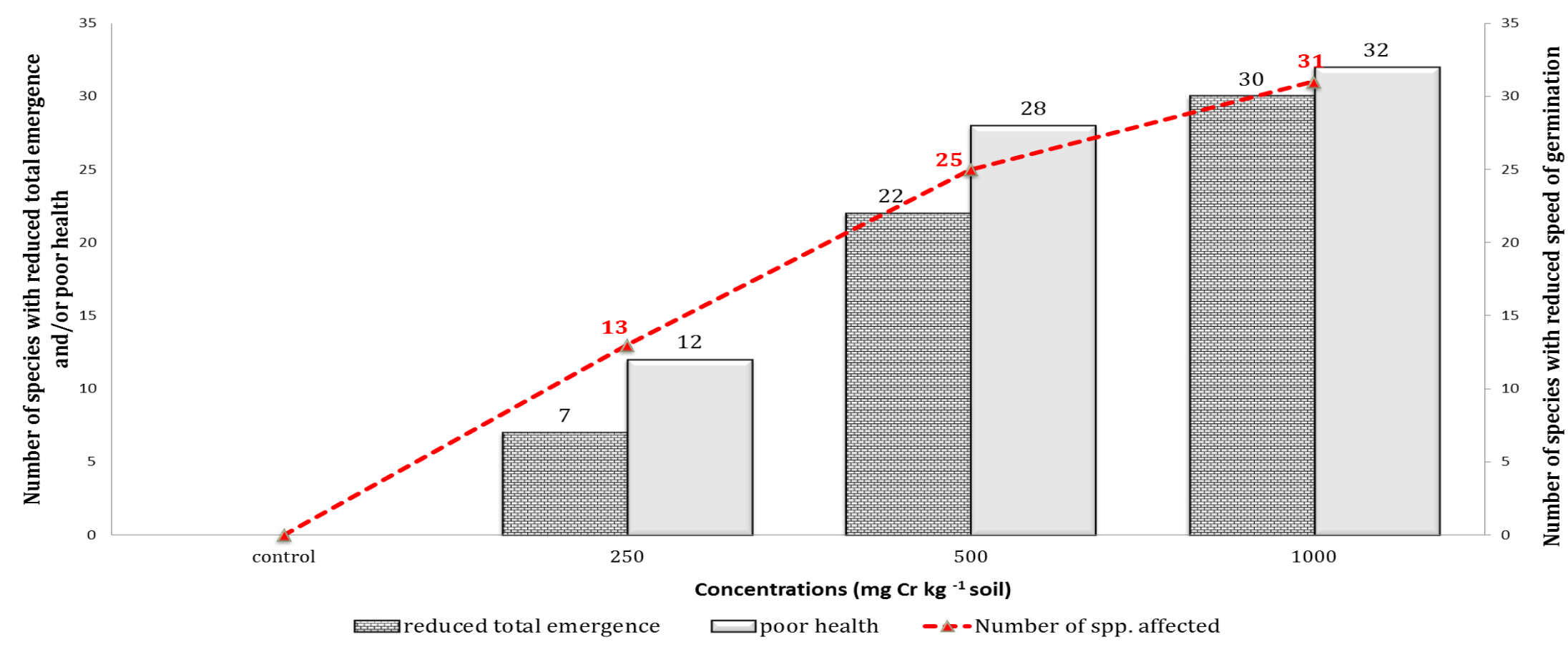

Figure 4: Number of non-stratified plant species exhibiting significant negative effects (as compared to the controls) on total germination [striped bars] and healthy seedlings [grey bars] assessed via pairwise Fisher's Exact test (refer to Appendix 4 for detailed results). All 32 species were exposed to chromium for one month during the concentration-response experiment in the growth chambers. Poor health was defined based on seedlings with reduced root length and hypocotyl height, light discolorations, wilting and/or rotting. In addition, the significant negative effect of chromium on the cumulative speed of germination [red line] (seed germination only) was assessed via either one-way ANOVA or Kruskal-Wallis tests. The lowest observed effect concentration (LOEC) of chromium on the rate of germination of each species was estimated from a significant difference using either Dunnett's or Savage post-hoc tests. Refer to Appendix 5 for detailed results. 


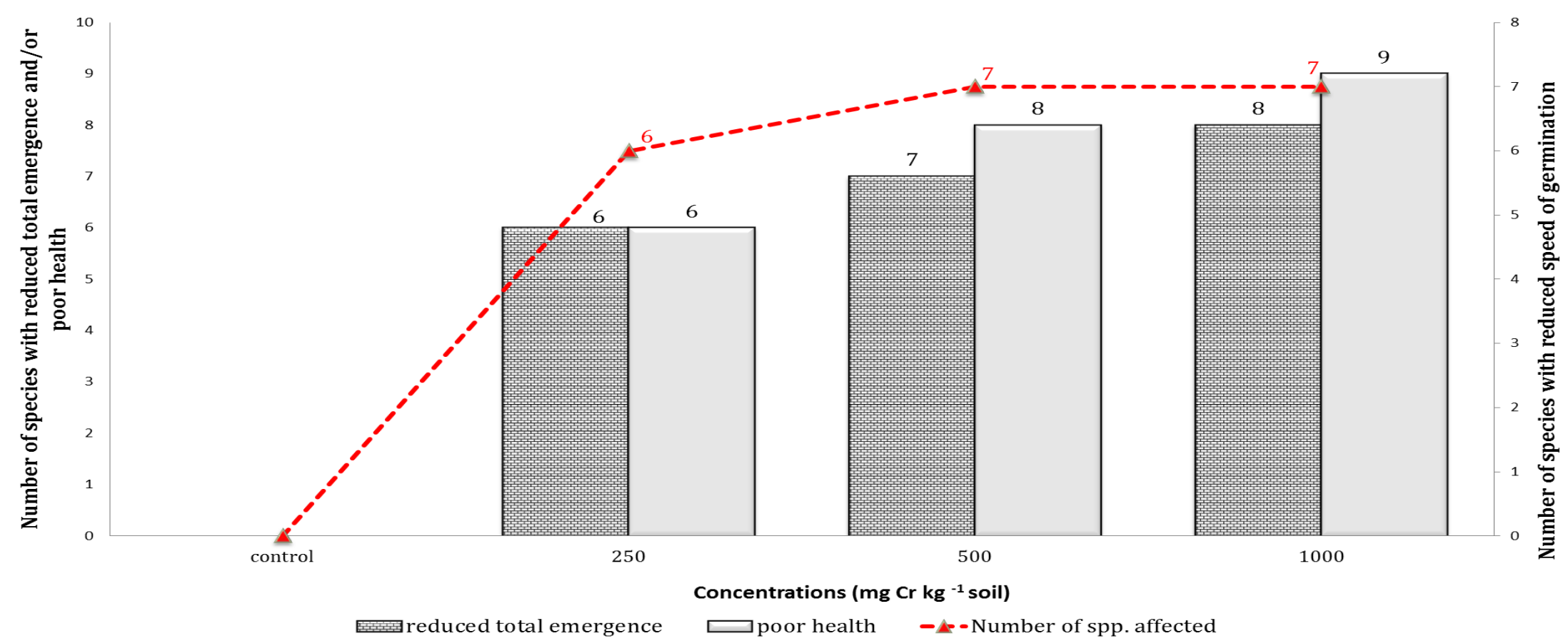

Figure 5: Number of stratified plant species exhibiting significant negative effects (as compared to the controls) on total germination [striped bars] and healthy seedlings [grey bars] assessed via pairwise Fisher's Exact test (refer to Appendix 4 for detailed results). All nine species were exposed to chromium during a four to eight week stratification period (refer to Table 1) in a dark refrigerator at 4 ${ }^{0} \mathrm{C}$, as well as for a one month concentration-response experiment in the growth chambers. Poor health was defined based on seedlings with reduced root length and hypocotyl height, light discolorations, wilting and/or rotting. In addition, the significant negative effect of chromium on the cumulative speed of germination [red line] (seed germination only) was assessed via either one-way ANOVA or Kruskal-Wallis tests. The lowest observed effect concentration (LOEC) of chromium on the rate of germination of each species was estimated from a significant difference using either Dunnett's or Savage post-hoc tests. Refer to Appendix 5 for detailed results. 
Table 3: Percent germination at 250, 500 and $1000 \mathrm{mg} \mathrm{kg}^{-1}$ chromium (CrIII) concentrations for non-stratified seeds/stratified seeds each normalized to their control percent germination. Seeds were exposed to chromium either for a one month concentration-response experiment in the growth chambers (non-stratified) or seeds were exposed to chromium during a four to eight week stratification treatment (refer to Table 1) and a one month concentration-response experiment (stratified). To test for the difference in responses between stratified and non-stratified seeds, Mantel-Haenszel analysis $\left(\mathrm{X}^{2}{ }_{\mathrm{MH}} / \mathrm{df} / \mathrm{p}\right.$-value $)$ was used. Total germinated seeds [in clear] and only healthy seedlings evaluated via visual assessment [in grey] are presented. Significant statistical effect is highlighted in bold.

\begin{tabular}{ccccccc}
\hline & \multicolumn{2}{c}{ Chromium concentrations $\left(\mathrm{mg} \mathrm{kg}^{-1}\right)$} & \multicolumn{3}{c}{ Mantel-Haenszel Test } \\
Selected stratified plants & 250 & 500 & 1000 & $\mathrm{X}^{2} \mathrm{MH}^{2}$ & $\mathrm{df}$ & $\mathrm{p}$-value \\
\hline A. balsamea & $56.00 / 28.00$ & $29.60 / 2.40$ & $3.20 / 0.80$ & 51.9443 & 1 & $<\mathbf{0 . 0 0 1}$ \\
& $56.00 / 28.00$ & $28.00 / 2.40$ & $3.20 / 0.80$ & 49.7878 & 1 & $<\mathbf{0 . 0 0 1}$ \\
P. mariana & $77.60 / 83.20$ & $62.22 / 64.00$ & $48.00 / 18.40$ & 7.6121 & 1 & $\mathbf{0 . 0 0 6}$ \\
& $77.60 / 83.20$ & $62.22 / 64.00$ & $48.00 / 18.40$ & 7.6121 & 1 & $\mathbf{0 . 0 0 6}$ \\
P. banksiana & $93.60 / 91.20$ & $92.80 / 84.00$ & $76.00 / 43.20$ & 29.1417 & 1 & $<\mathbf{0 . 0 0 1}$ \\
& $93.60 / 91.20$ & $92.80 / 79.20$ & $65.60 / 33.60$ & 32.5514 & 1 & $<\mathbf{0 . 0 0 1}$ \\
G. procumbens & $11.20 / 6.40$ & $8.80 / 1.60$ & $0 / 0$ & 6.9192 & 1 & $\mathbf{0 . 0 0 9}$ \\
& $11.20 / 6.40$ & $5.60 / 1.60$ & $0 / 0$ & 4.1933 & 1 & $\mathbf{0 . 0 4 1}$ \\
S. canadensis & $26.40 / 26.40$ & $29.60 / 12.00$ & $20.00 / 7.20$ & 12.0721 & 1 & $<\mathbf{0 . 0 0 1}$ \\
& $26.40 / 24.80$ & $26.40 / 8.00$ & $10.40 / 2.40$ & 12.4251 & 1 & $<\mathbf{0 . 0 0 1}$ \\
E. maculatum & $17.60 / 2.40$ & $11.20 / 4.00$ & $3.20 / 0.80$ & 21.2910 & 1 & $<\mathbf{0 . 0 0 1}$ \\
& $16.80 / 2.40$ & $5.60 / 4.00$ & $0 / 0$ & 12.0290 & 1 & $<\mathbf{0 . 0 0 1}$ \\
A. syriaca & $66.40 / 37.60$ & $51.20 / 16.00$ & $26.40 / 5.60$ & 73.7340 & 1 & $<\mathbf{0 . 0 0 1}$ \\
H. perforatum & $64.80 / 37.60$ & $43.20 / 12.80$ & $8.00 / 1.60$ & 51.2873 & 1 & $<\mathbf{0 . 0 0 1}$ \\
& $36.00 / 11.20$ & $32.80 / 4.80$ & $28.80 / 3.20$ & 81.8691 & 1 & $<\mathbf{0 . 0 0 1}$ \\
& $36.00 / 8.80$ & $24.80 / 4.00$ & $2.40 / 0.80$ & 48.9544 & 1 & $<\mathbf{0 . 0 0 1}$
\end{tabular}




$\begin{array}{llllll}44.00 / 1.60 & 40.80 / 1.60 & 7.20 / 0.80 & 126.369 & 1 & <\mathbf{0 . 0 0 1}\end{array}$




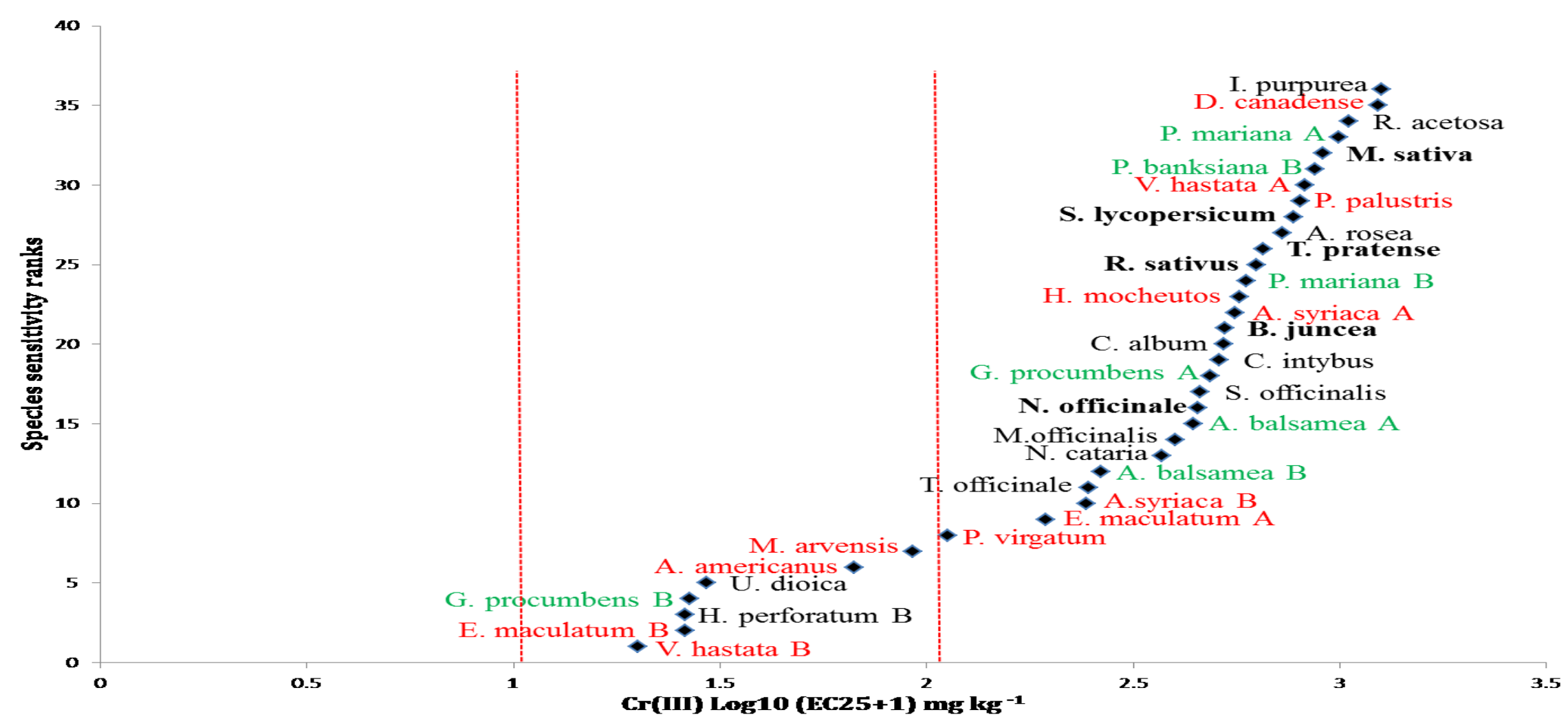

Figure 6: Species sensitivity ranks using estimated EC25s (effective concentration causing 25\% reduction in species germination) for the tested species exposed to CrIII during the concentration-response experiment either without stratification [A] or with stratification [B] treatment. Tested species were separated into native herbs [highlighted in red], native woody [highlighted in green], introduced crops [in bold] and introduced forbs [in black]. Dashed red lines represent the natural range of chromium (10-100 mg kg $\left.{ }^{-1}\right)$ in soil. The EC25 could not be estimated in four cases (three species) since monotonic concentration-response effect was not found, and the non-stratified P. banksiana had EC25 greater than the maximum concentration (refer to Appendix 6 for details). 
Table 4: Germination of plant species with diverse taxonomic and ecological traits when exposed to 250,500 and $1000 \mathrm{mg} \mathrm{kg}^{-1}$ chromium (CrIII) concentrations as compared to controls during the concentration-response experiment. Mantel-Haenszel analysis $\left(\mathrm{X}^{2}{ }_{\mathrm{MH}} / \mathrm{df} / \mathrm{p}\right.$-value) was used to test for the difference in responses using all germinating seeds [in clear] and only using healthy seedlings determined via visual assessment [in grey]. Significant differences are highlighted in bold.

\begin{tabular}{ccccccc}
\hline Plant Traits & \multicolumn{3}{c}{ Chromium concentrations $\left(\mathrm{mg} \mathrm{kg}^{-1}\right)$} & \multicolumn{3}{c}{ Mantel-Haenszel Test } \\
& 250 & 500 & 1000 & $\mathrm{X}_{\mathrm{MH}}^{2}$ & $\mathrm{df}$ & $\mathrm{p}$-value \\
\hline Monocots/Dicots & $39.47 / 55.94$ & $30.40 / 42.59$ & $8.00 / 18.18$ & 80.9717 & 1 & $<\mathbf{0 . 0 0 1}$ \\
& $35.20 / 53.05$ & $28.53 / 30.48$ & $6.40 / 7.36$ & 27.6961 & 1 & $<\mathbf{0 . 0 0 1}$ \\
Native/Introduced & $45.23 / 62.49$ & $37.55 / 44.89$ & $19.41 / 15.29$ & 66.0517 & 1 & $<\mathbf{0 . 0 0 1}$ \\
& $42.83 / 58.92$ & $31.88 / 28.89$ & $11.89 / 3.17$ & 3.6244 & 1 & 0.057 \\
Wetland/Upland & $46.04 / 58.78$ & $36.36 / 44.11$ & $14.33 / 18.74$ & 88.3908 & 1 & $<\mathbf{0 . 0 0 1}$ \\
& $42.33 / 56.11$ & $28.45 / 31.28$ & $8.51 / 6.62$ & 37.0196 & 1 & $<\mathbf{0 . 0 0 1}$ \\
Crops/Non-crops & $79.20 / 48.68$ & $61.60 / 36.80$ & $15.73 / 17.57$ & 275.1965 & 1 & $<\mathbf{0 . 0 0 1}$ \\
& $74.80 / 45.97$ & $35.07 / 29.20$ & $4.59 / 7.88$ & 114.1838 & 1 & $<\mathbf{0 . 0 0 1}$ \\
Growth habit: & & & & & & \\
Woody/Forbs & $52.96 / 55.14$ & $43.68 / 41.25$ & $28.00 / 15.71$ & 12.8660 & 1 & $<\mathbf{0 . 0 0 1}$ \\
& $52.96 / 51.26$ & $40.47 / 27.58$ & $23.52 / 3.85$ & 116.8232 & 1 & $<\mathbf{0 . 0 0 1}$ \\
Graminoids/Forbs & $48.80 / 55.14$ & $38.40 / 41.25$ & $9.20 / 15.71$ & 9.2119 & 1 & $\mathbf{0 . 0 0 2}$ \\
& $48.80 / 51.26$ & $38.40 / 27.58$ & $9.20 / 3.85$ & 8.7930 & 1 & $\mathbf{0 . 0 0 3}$ \\
Woody/Graminoids & $52.96 / 48.80$ & $40.47 / 38.40$ & $28.00 / 9.20$ & 21.2742 & 1 & $<\mathbf{0 . 0 0 1}$ \\
& $52.96 / 48.80$ & $40.47 / 38.40$ & $23.52 / 9.20$ & 11.6542 & 1 & $<\mathbf{0 . 0 0 1}$ \\
\hline
\end{tabular}




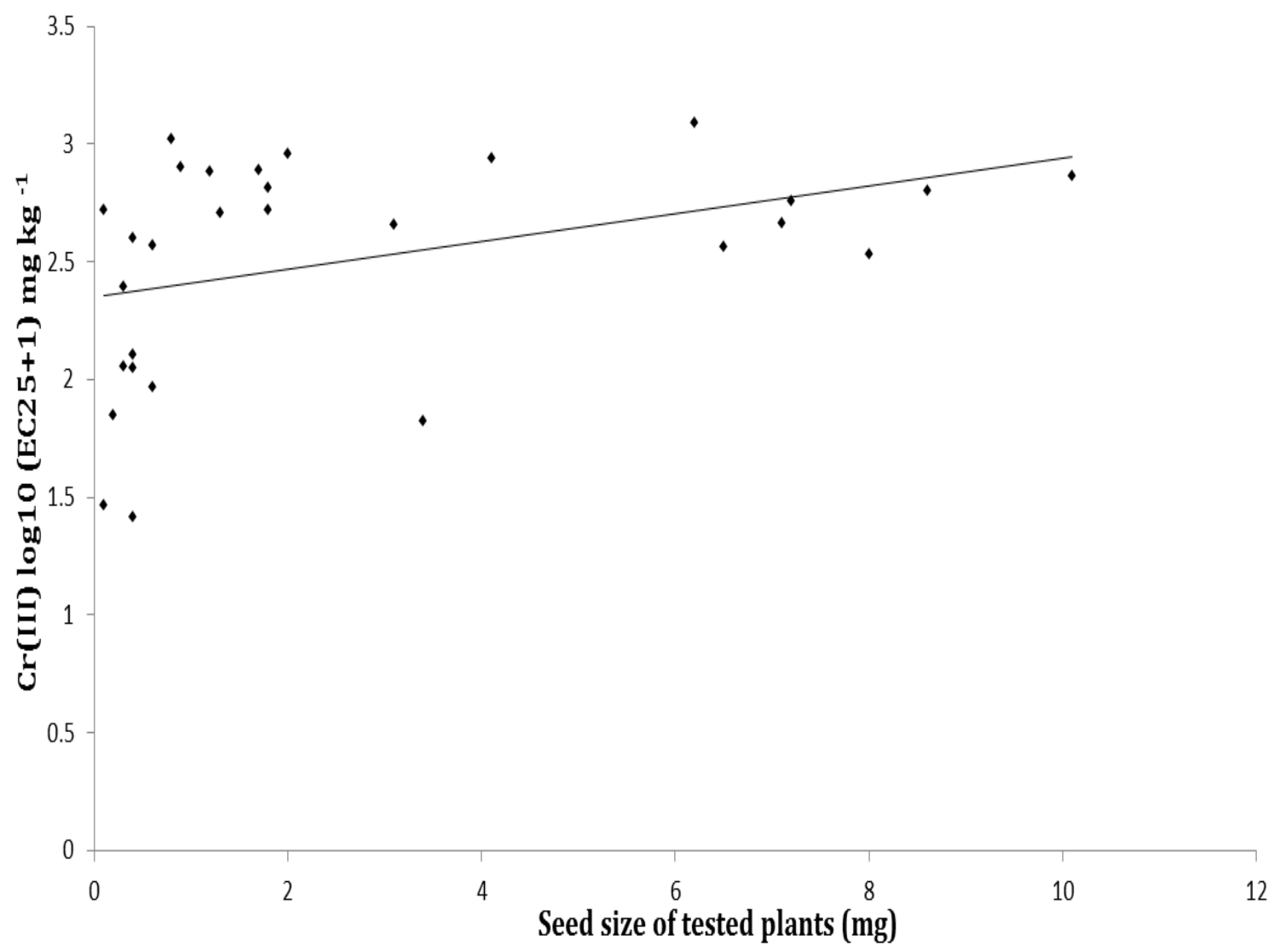

Figure 7: Significant positive trend between seed sizes of tested plant species and estimated EC25s (effective concentration causing $25 \%$ reduction in species germination) $\left(\mathrm{R}^{2}=0.150\right)$. An average of pre- and post-contamination EC25 was calculated for eight species (excluding S. canadensis which was tolerant in both conditions). Additionally, EC25 could not be estimated for three cases, including P. tremuloides, H. perforatum, and $P$. banksiana. Ipomoea purpurea was also excluded from the analysis due to its very large seed size compared to the rest of the plant species. 
Table 5: Characteristics of 38 plant species from 20 botanical families that emerged from the seed bank soils from Nibinamik traditional/reserve land, Ontario, Canada. Twenty four species from 15 families emerged during the concentration-response experiment. The seed bank soils containing those seeds were stratified for a one month in a dark refrigerator at $4{ }^{0} \mathrm{C}$ and then placed in the growth chamber for the experiment that occurred from October, 2014 to April, 2015. Additionally, 14 species from 11 families emerged from large containers with uncontaminated seed bank soils, which were used to aid in identifying emerged species and for further comparison to seedlings from Petri dishes. Species scientific names were obtained from the USDA Plants Database (http://www.plants.usda.gov/java/) and from the Database of Vascular Plants of Canada (VASCAN) (http://data.canadensys.net/vascan/search). Species are separated into gymnosperms and angiosperms as well as into monocots and dicots. Dicots are further separated into woody (i.e. trees and shrubs) and herbs. Lifespan is represented as annual (A), biennial (B) and perennial (P) (http://www.plants.usda.gov/java/). Habitat was divided into several categories, as follows: OBL (obligate wetland) - plant species almost always found in wetlands under natural conditions ( $>90 \%$ probability), FACW (facultative wetland) - usually found in wetlands, but occasionally found in non-wetlands (67-89\%), FAC (facultative) - equally likely to occur in wetlands or nonwetlands (34-66\%), FACU (facultative upland) - occasionally occurs in wetlands, but usually found in non-wetlands (1-33\%), and UPL (obligate upland) - almost never found in wetlands under natural conditions $(<1 \%)$ (Oldham et al., 1995). N status means that plant species are native to Ontario.

\begin{tabular}{|c|c|c|c|c|c|c|}
\hline \multirow[t]{4}{*}{$\begin{array}{l}\text { Concentration- } \\
\text { response }\end{array}$} & \multicolumn{6}{|c|}{$\underline{\text { Angiosperms monocots }}$} \\
\hline & $\begin{array}{c}\text { Calamagrostis canadensis } \\
\text { (Michx.) P. Beauv. }\end{array}$ & Bluejoint reedgrass & Poaceae & $\mathrm{P}$ & OBL & $\mathrm{N}$ \\
\hline & Carex spp. 1 & & Cyperaceae & & & \\
\hline & Grass spp. 1 & & Poaceae & & & \\
\hline
\end{tabular}




\begin{tabular}{|c|c|c|c|c|c|c|}
\hline & & Dicots Woody & & & & \\
\hline & Ribes hudsonianum Richardson & Northern black current & Grossulariaceae & $\mathrm{P}$ & OBL & $\mathrm{N}$ \\
\hline & Diervilla lonicera Mill. & Northern bush honeysuckle & Caprifoliaceae & $\mathrm{P}$ & UPL & $\mathrm{N}$ \\
\hline & Rubus idaeus L. & Wild raspberry & Rosaceae & $\mathrm{P}$ & FACW & $\mathrm{N}$ \\
\hline & Betula papyrifera Marshall & White birch & Betulaceae & $\mathrm{P}$ & FACU & $\mathrm{N}$ \\
\hline & Ribes triste Pall. & Red currant & Grossulariaceae & $\mathrm{P}$ & OBL & N \\
\hline & Vaccinium angustifolium Aiton & Early lowbush blueberry & Ericaceae & $\mathrm{P}$ & FACU & $\mathrm{N}$ \\
\hline & Vaccinium oxycoccos L. & Small cranberry & Ericaceae & $\mathrm{P}$ & OBL & N \\
\hline & Chamaedaphne calyculata (L.) Moench & Leatherleaf & Ericaceae & $\mathrm{P}$ & OBL & N \\
\hline & Ledum groenlandicum Oeder & bog Labrador tea & Ericaceae & $\mathrm{P}$ & OBL & N \\
\hline & Cornus canadensis L. & Bunchberry & Cornaceae & $\mathrm{P}$ & FAC & $\mathrm{N}$ \\
\hline & & Forbs & & & & \\
\hline & Lycopus uniflorus Michx. & Northern bugleweed & Lamiaceae & $\mathrm{P}$ & OBL & N \\
\hline & Potentilla norvegica $\mathrm{L}$. & Rough cinquefoil & Rosaceae & $\mathrm{A} / \mathrm{B} / \mathrm{P}$ & FAC & N \\
\hline & $\begin{array}{l}\text { Chamerion angustifolium (L.) Holub } \\
\text { subsp. angustifolium }\end{array}$ & Fireweed & Onagraceae & $\mathrm{P}$ & FAC & $\mathrm{N}$ \\
\hline & Viola palustris L. & Northern marsh violet & Violaceae & $\mathrm{P}$ & OBL & $\mathrm{N}$ \\
\hline & $\begin{array}{c}\text { Symphyotrichum cordifolium (L.) G.L. } \\
\text { Nesom }\end{array}$ & Common blue wood aster & Asteraceae & $\mathrm{P}$ & UPL & $\mathrm{N}$ \\
\hline & Galium triflorum Michx. & Fragrant bedstraw & Rubiaceae & $\mathrm{P}$ & FACU & \\
\hline & Solidago canadensis L. & Canada goldenrod & Asteraceae & $\mathrm{P}$ & FACU & N \\
\hline & Rorippa palustris (L.) Besser & Bog yellowcress & Brassicaceae & $\mathrm{A} / \mathrm{B} / \mathrm{P}$ & OBL & N \\
\hline & Rubus pubescens Raf. & Dwarf red blackberry & Rosaceae & $\mathrm{P}$ & FACW & 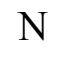 \\
\hline Containers & & Gymnosperms & & & & \\
\hline & Picea mariana (Mill.) Britton, Sterns \& & Black spruce & Pinaceae & $\mathrm{P}$ & FACW & \\
\hline
\end{tabular}


Poggenb.

Grass spp. 2

Carex spp. 3

Carex spp. 4

Carex spp. 5

Cornus stolonifera Michx.

Vaccinium myrtilloides Michx.

Salix candida Flüeggé ex. Willd.

Galium trifidum L.

Fragaria virginiana Mill.

Epilobium strictum Muhl. ex. Spreng.

Corydalis flavula (Raf.) DC.

Mitella nuda L.

Podophyllum peltatum L.

\begin{tabular}{ccccc}
\hline & $\begin{array}{c}\text { Cyperaceae } \\
\text { Cyperaceae }\end{array}$ & & & \\
& $\begin{array}{c}\text { Cyperaceae } \\
\text { Cyperaceae }\end{array}$ & & & \\
Dicots Woody & & & & \\
Red-osier dogwood & Cornaceae & P & FACW & N \\
Velvetleaf huckleberry & Ericaceae & P & FACW & N \\
Sage willow & Salicaceae & P & OBL & N \\
Forbs & & & & \\
Rree-petalled bedstraw & Rubiaceae & P & FACW & N \\
Wild strawberry & Rosaceae & P & FAC & N \\
Downy willowherb & Onagraceae & P & OBL & N \\
Yellow corydalis & Fumariaceae & A & FACW & N \\
Naked miterwort & Saxifragaceae & P & FACW & N \\
May-apple & Berberidaceae & P & FACU & N \\
\hline
\end{tabular}



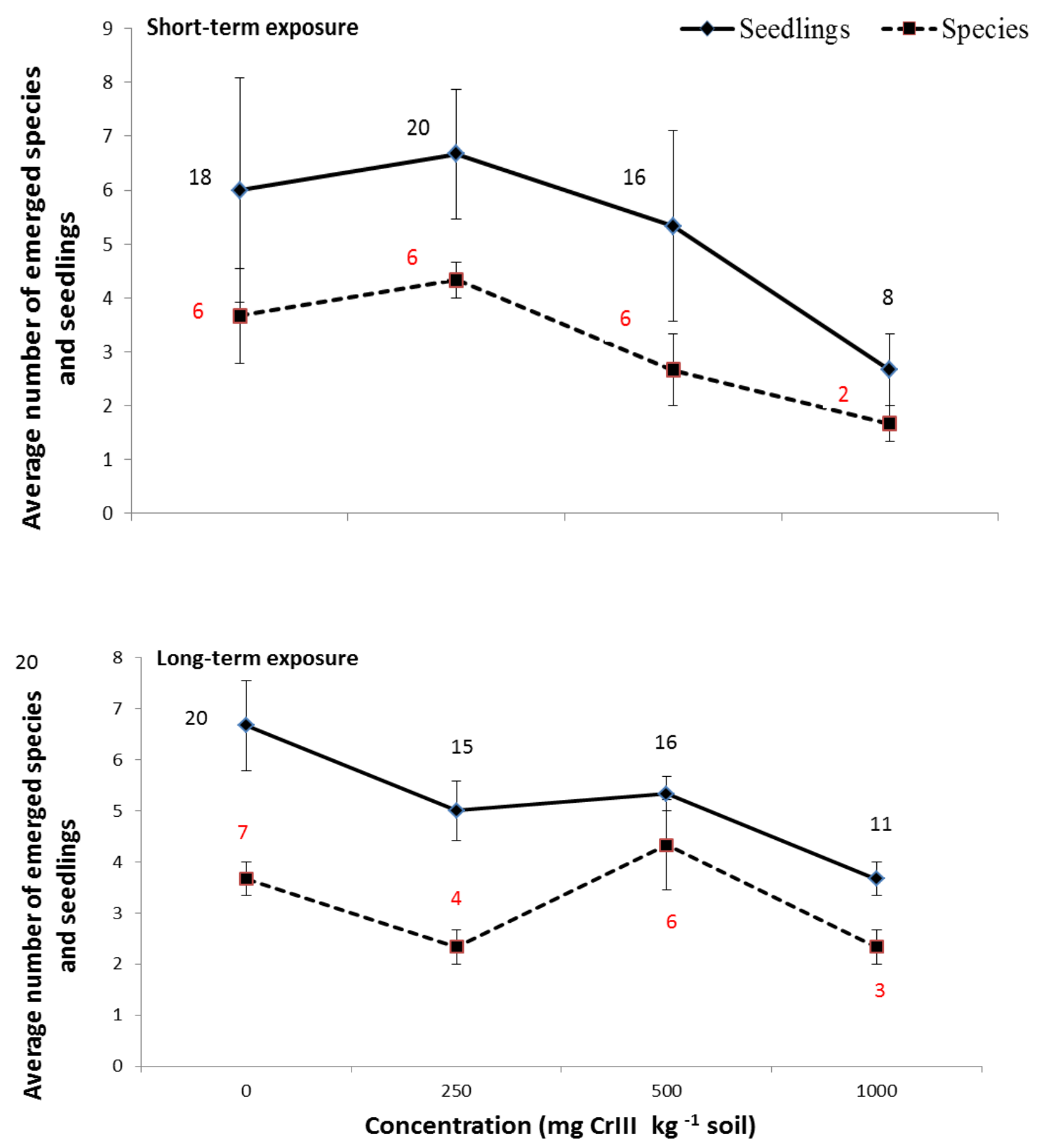

Figure 8: Average number of plant species and seedlings from the seed bank soils collected in the shores of Bucheski Lake in Nibinamik traditional/reserve land, Ontario. Short-term exposure: soil was stratified for one month and then was exposed to three chromium (CrIII) concentrations plus controls in a growth chamber starting from October $21^{\text {st }}, 2014$ to April $21^{\text {st }}, 2015$. Long-term exposure: soil was exposed to three chromium concentrations during stratification for one month prior to the concentration-response experiment in the growth chamber. Total numbers of species are indicated in red and total numbers of seedlings in black. Error bars represent standard errors. 

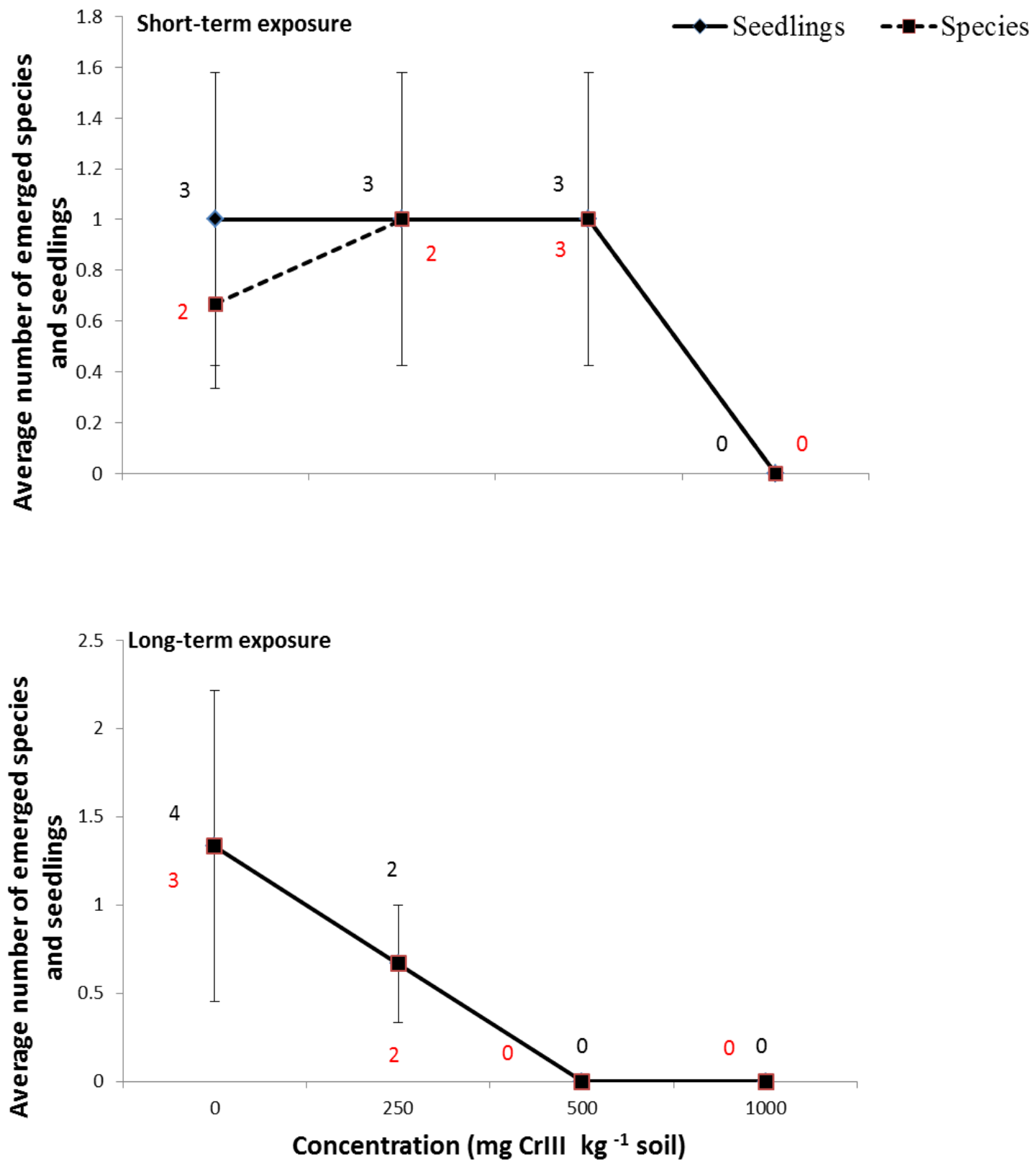

Figure 9: Average number of plant species and seedlings from the seed bank soils collected in the upland woody area in Nibinamik traditional/reserve land, Ontario. Shortterm exposure: soil was stratified for one month and then was exposed to three chromium (CrIII) concentrations plus controls in a growth chamber starting from October $21^{\text {st }}, 2014$ to April $21^{\text {st }}, 2015$. Long-term exposure: soil was exposed to three chromium concentrations during stratification for one month prior to the concentration-response experiment in the growth chamber. Total numbers of species are indicated in red and total numbers of seedlings in black. Error bars represent standard errors. 

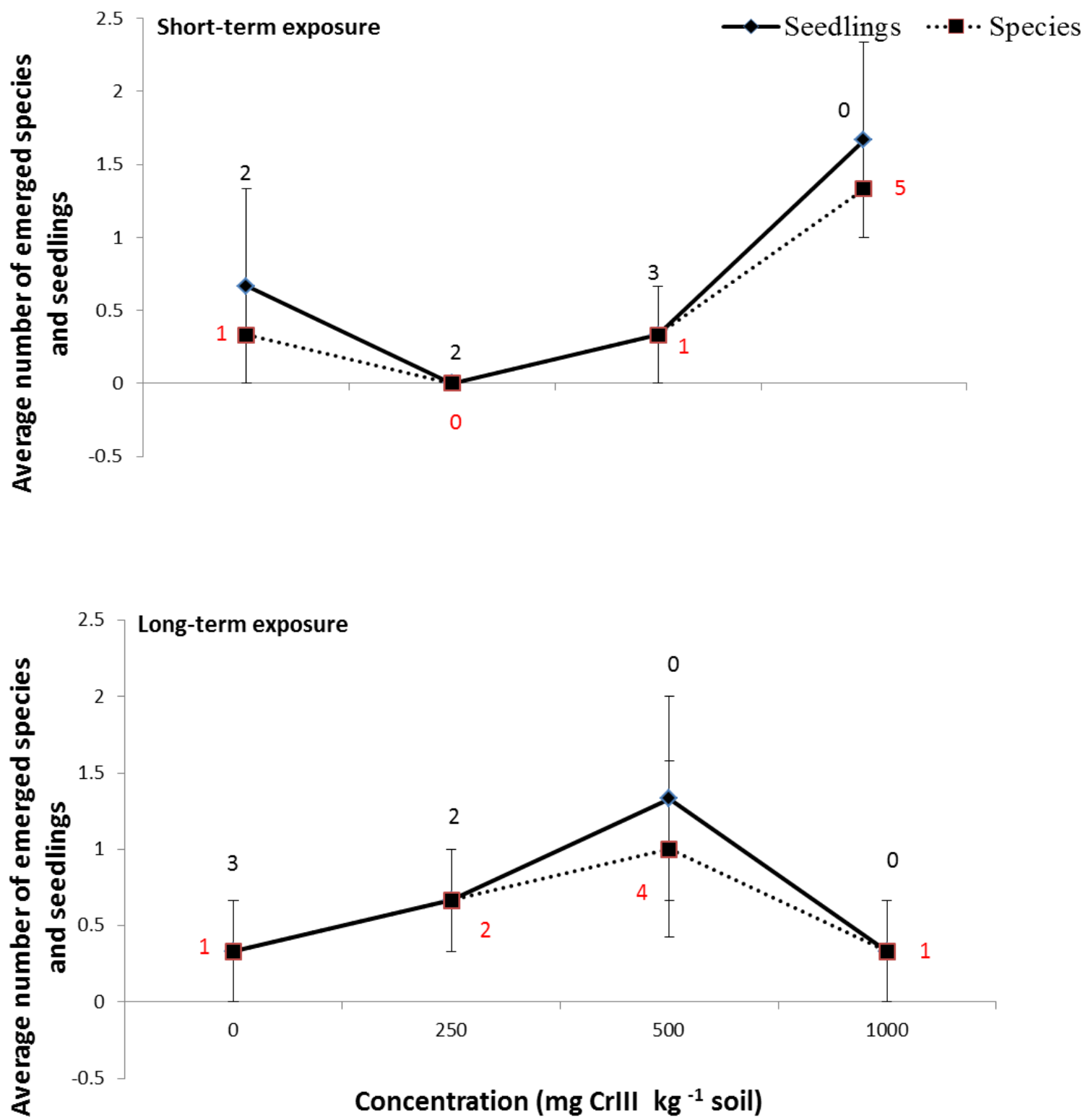

Figure 10: Average number of plant species and seedlings from the seed bank soils collected in the wetland habitat in Nibinamik traditional/reserve land, Ontario. Short-term exposure: soil was stratified for one month and then was exposed to three chromium (CrIII) concentrations plus controls in a growth chamber starting from October $27^{\text {th }}, 2014$ to April $27^{\text {th }}, 2015$. Long-term exposure: soil was exposed to three chromium concentrations during stratification for one month prior to the concentration-response experiment in the growth chamber. Total numbers of species are indicated in red and total numbers of seedlings in black. Error bars represent standard errors. 

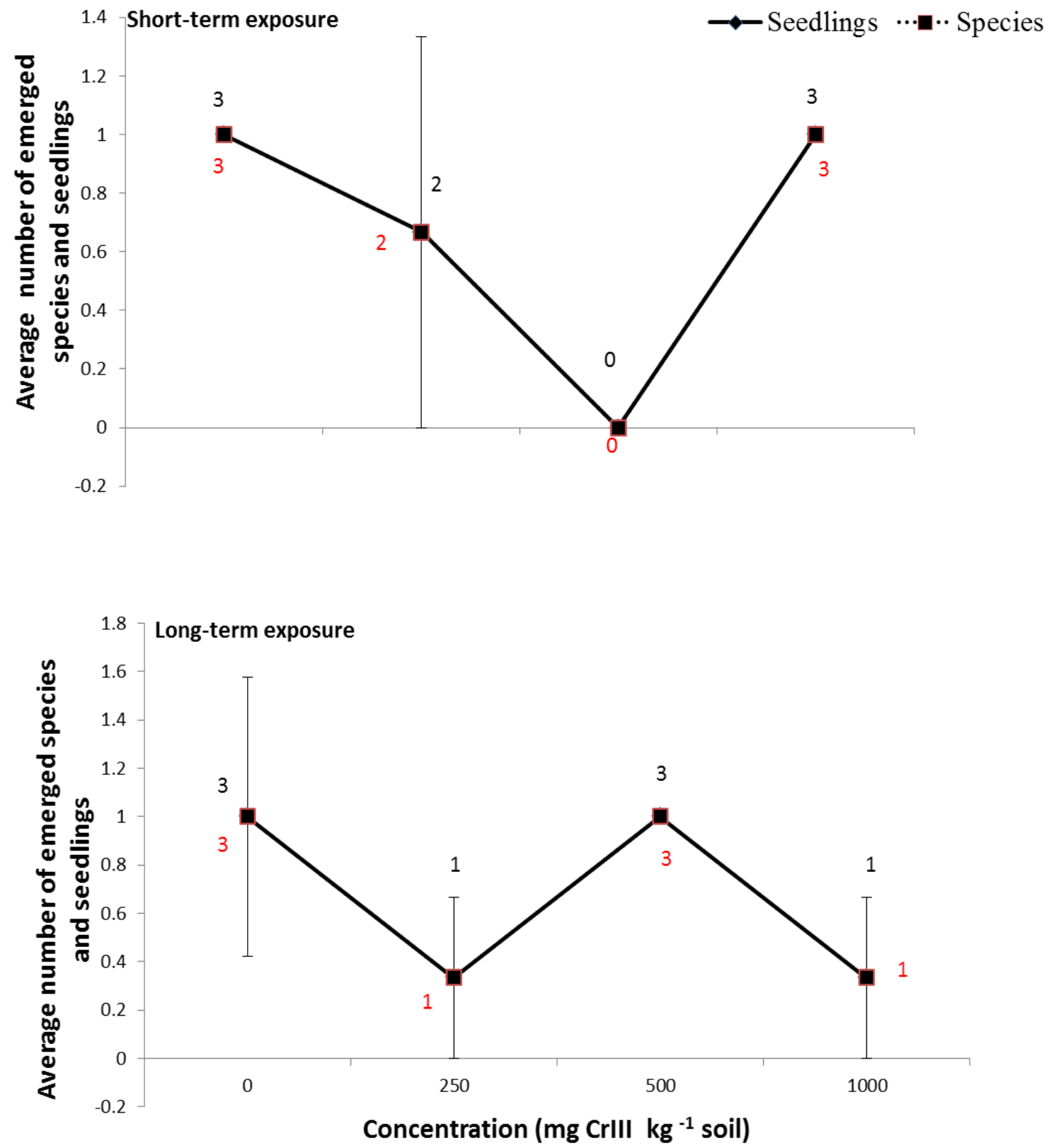

Figure 11: Average number of plant species and seedlings from the seed bank soils collected at the banks of Winisk River in Nibinamik traditional/reserve land, Ontario. Short-term exposure: soil was stratified for one month and then was exposed to three chromium (CrIII) concentrations plus controls in a growth chamber starting from October $27^{\text {th }}, 2014$ to April $27^{\text {th }}, 2015$. Long-term exposure: soil was exposed to three chromium concentrations during stratification for one month prior to the concentration-response experiment in the growth chamber. Total numbers of species are indicated in red and total numbers of seedlings in black. Error bars represent standard errors. 
Table 6: Summary of Poisson regression statistical results (Wald Chi-Square/df/p-value) under the Generalized Linear Model framework for the plant species and seedlings emerging from the seed bank soils of four sampled sites from Nibinamik traditional/reserve land, Ontario, Canada. Soils were exposed to three chromium (CrIII) concentrations plus controls during the concentration-response experiment. To test for possible difference in responses, soils were exposed to chromium before and after stratification (condition). In addition, an interaction between concentrations and condition was also considered. Significant differences are highlighted in bold.

\begin{tabular}{cccc}
\hline & Concentration & Condition & Concentration *Condition \\
\hline Lake & & & \\
seedlings & $6.441 / 1 / \mathbf{0 . 0 1 1}$ & $0.107 / 1 / 0.744$ & $0.208 / 1 / 0.648$ \\
species & $2.834 / 1 / 0.092$ & $0.303 / 1 / 0.582$ & $0.755 / 1 / 0.385$ \\
Upland & & & \\
seedlings & $5.658 / 1 / \mathbf{0 . 0 1 7}$ & $0.031 / 1 / 0.860$ & $1.472 / 1 / 0.225$ \\
species & $5.104 / 1 / \mathbf{0 . 0 2 4}$ & $0.234 / 1 / 0.629$ & $1.777 / 1 / 0.183$ \\
Wetland & & & \\
seedlings & $1.667 / 1 / 0.197$ & $1.128 / 1 / 0.288$ & $1.667 / 1 / 0.197$ \\
species & $1.940 / 1 / 0.164$ & $1.801 / 1 / 0.180$ & $2.179 / 1 / 0.140$ \\
River & & & \\
seedlings & $0.274 / 1 / 0.601$ & $0.150 / 1 / 0.699$ & $0.274 / 1 / 0.601$ \\
species & $0.274 / 1 / 0.601$ & $0.150 / 1 / 0.699$ & $0.274 / 1 / 0.601$ \\
\hline
\end{tabular}




\section{Chapter 4: Discussion}

The current research study demonstrated the effects of chromium (CrIII) toxicity on a wide range of terrestrial plants. Seeds of 32 species from 18 families were exposed to chromium concentrations representing both natural levels and those that could originate from man-made activities (i.e. mining of chromite ore). The species selected for this study were diverse in their ecological, taxonomic, morphological and functional characteristics, and these chosen species are commonly found in different habitats, including croplands, meadows, riparian zones and forests. Crop species were chosen for comparison purposes in risk assessment. In addition, effects on species emerging from a seed bank soils were assessed. This study revealed that a wide range of species would be affected at low to medium levels of chromium contamination found in the environment.

\subsection{Growth conditions}

The bioavailability and uptake of chromium by plants may depend on the characteristics of the metal itself (Rai et al., 1989; Fendorf, 1995) and the physicochemical attributes of the soil, including cationic exchange capacity (Kanbar et al., 2014), presence of natural inorganic oxides (Kotas \& Stasicka, 2000), pH ranges (Rai et al., 1989; Palmer \& Wittbrodt, 1991), and soil texture (Fernandes et al., 2002; Davies et al., 2002; Sharma et al., 2005). Once in the environment, trivalent chromium strongly binds to hydroxide complexes and at acidic $\mathrm{pH}$ ranges (usually below 6) becomes mobile and available to living organisms (Kotas \& Stasicka, 2000). In our case, the soil pH (for two prepared batches of artificial soil) was acidic and fairly constant (5.85 to 5.70), 
allowing us to conclude that chromium was available to the treated seeds. Cationic exchange capacity (CEC) defines the soil's ability to retain positively charged ions and is an important indicator of soil fertility, structure stability and nutrient availability; a higher CEC means that the soil is fertile and more nutrients are available to plants. An organic soil that has a relatively high CEC (up to a 100 meg $100 \mathrm{~g}^{-1}$ of soil) diminishes the movement of metals within the growth medium and their further uptake by plants (Kotas \& Stasicka, 2000; Kanbar et al., 2014). In artificial soil, the organic matter content and the average measured CEC were $12.16 \%$ and $16.8 \mathrm{meg} 100 \mathrm{~g}^{-1}$ respectively, meaning that chromium could be absorbed by the emerged seedlings. The growing conditions in artificial soil can thus represent a worst-case scenario when assessing the mobility, bioavailability and toxicity of chromium.

In the seed bank study, the $\mathrm{pH}$ was acidic in the upland site (5.1) only, and almost neutral for the lake, wetland, and river sites with $\mathrm{pH}$ values of $6.9,7.3$ and 6.5 respectively; such neutral soil $\mathrm{pHs}$ make chromium less mobile within the soil matrix and likely less available to plants. Meanwhile, both CEC and organic matter content were comparable between the lake seed banks and artificial soil, concluding that concentrationresponse effects could be similar for plants emerging in those soils. On the contrary, soil from the wetland site consisting of pure peat had an exceptionally high organic matter content (81.2\%) and CEC (137 meg $\left.100 \mathrm{~g}^{-1}\right)$ indicating that chromium was not as readily absorbed into the seedling tissues. Such differences between the controlled artificial environment and the natural soils could explain why unhealthy seedlings were not observed in the seed bank study. A study by Bluskov et al. (2005) determined that 
trivalent chromium was bioavailable to $B$. juncea with consecutive accumulation of chromium by plants grown in soil containing $5.13 \mathrm{pH}, 2.37 \%$ organic matter and $>100$ mg $\mathrm{kg}^{-1}$ of chromium. Also, chromium negatively affected $R$. sativus, when seedlings were grown in the stagnic luvisol soil with $5.9 \mathrm{pH}$, as well as with organic matter and CEC values of $10 \%$ and 8.7 meg $100 \mathrm{~g}^{-1}$, correspondingly (Fernandes et al., 2002). An (2004) found that cadmium was mobile and available, thus hazardous to Z. mays, S. bicolor, T. aestivum, and Cucumis sativus L. (Cucurbitaceae) when plants were grown in soil with sandy loam texture, $4.3 \mathrm{pH}$ and containing only $0.3 \%$ organic matter.

Several studies have suggested that nutrient levels in soil may play a significant role when assessing metal bioavailability and toxicity to plants. Smith et al. (2013) found that there was a significant interaction between the nitrogen, phosphorus and potassium levels in soil and vanadium toxicity with increasing plant sensitivity to the metal under low nutrient levels. Similarly, chromium had an adverse effect on $H$. annuиs when species were grown in soil with diminished nutrient levels (i.e. nitrogen, phosphorus, calcium, manganese, potassium, zinc, to name a few) (Davies et al., 2002). In our case, the low levels of ammonium, nitrate and phosphorus were detected in the upland soils where there was a decrease in the numbers of species and seedlings with increasing concentrations.

The levels of 27 other metals within the growth medium were also considered when assessing plant response. In the artificial soil, the background concentrations of none of the 27 metals exceeded their maximum natural level, as well as the recommended Canadian soil quality guidelines (Appendix 1). On the contrary, in the natural seed bank 
soils the background level of manganese from the river soil was considerably higher than its maximum natural level, and the levels of other two metals (i.e. arsenic from river soil, and boron from the river and wetland soils) were higher (Appendix 2) than the soil quality guidelines for the protection of environmental and human health (CCME, 2015). Manganese and boron are considered important to plants; small quantities of both metals may stimulate plant growth and development. The levels of these two micronutrients without any toxic effects to plants may range from 15 to $25 \mathrm{mg} \mathrm{kg}^{-1}$ and from 5 to $30 \mathrm{mg}$ $\mathrm{kg}^{-1}$ respectively, within the plant tissues (Kabata-Pendias, 2011). Antagonistic (less of an observed adverse effect of two elements together) interactions were found between chromium and manganese in plant tissues of $R$. sativus (Abreu et al., 2002) and between chromium and boron in S. lycopersicum (Moral et al., 1996). Little is known regarding the possible interferences between the arsenic and chromium heavy metals in soil and plants. Kabata-Pendias (2011) stated that the natural level of arsenic in plant tissues ranges from 0.5 to $80 \mathrm{mg} \mathrm{kg}^{-1}$ fresh weight.

\subsection{Effect of chromium (CrIII) on plants}

Plants are valuable components of biological ecosystems; they produce oxygen, regulate water and nutrient cycles, and take up carbon dioxide for carbon fixation. Additionally, plants are essential for the diversity and composition of local fauna, and act as primary producers in the food chain (Hooper et al., 2005). Importantly, many of the selected wild plants are naturally found in various habitats in the Ring of Fire, a parcel of land containing large chromite ore deposits. In a natural environment with active chromium mining, sensitive species may be outcompeted by other tolerant species and 
may even go extinct. Many native species chosen for the concentration-response experiment in artificial soil were considerably more sensitive to chromium than the majority of introduced forbs along with herbaceous crops, although with some exceptions, including D. canadense, P. mariana, and P. banksiana (Figure 6; Appendix 6). Additionally, a few other native species emerged in the natural seed bank soils contaminated with high (> $\left.1000 \mathrm{mg} \mathrm{kg}^{-1}\right)$ levels of chromium, including C. canadensis, D. lonicera, R. idaeus, V. oxycoccos, P. norvegica, Rorippa palustris (L.) Besser (Brassicaceae), and Galium triflorum Michx. (Rubiaceae) (Appendices 7-10). Delays in emergence and poor seedling health as a result of chromium toxicity may impair growth and time to flower and may have direct implications on the diversity and abundance of pollinators (e.g. butterflies, bees) and other native insects (Potts et al., 2010). For instance, environmental pollution arising from waste rock and mine tailings may impact many keystone species, like $A$. syriaca which is considered a vital feeding source of Monarch butterflies (Danaus plexippus L.), and Hibiscus moscheutos L. (Malvaceae), Alcea rosea L. (Malvaceae) and I. purpurea, which are essential for many bumblebees (e.g. Melitoma taurea L.). Likewise, Notten et al. (2005) discovered a high correlation between concentrations of several heavy metals in the environment and in tissues of terrestrial gastropods (Cepaea nemoralis L.), which feed on the vegetation of contaminated $U$. dioica. Trees are essential for decreasing surface runoff, known to have a strong holding capacity and are also necessary for many wildlife species. Consequently, heavy metal pollution to the environment may significantly affect not only individual species, but the population, whole ecological community and natural ecosystem. 
Metals tend to affect seed germination by their direct toxicity (i.e. effect on lipids, proteins, and nucleic acids by oxidative stress) upon seed coat rupture (Kranner \& Colville, 2011). Germination of treated seeds may also be inhibited by decreasing activity of $\alpha$ - and $\beta$-amylase, which is responsible for the breakdown of starch molecules into glucose (Zeid, 2001). Chromium is also known to cause various morphological and functional changes within plant tissues. Such combined mode of action may result in reduced root and shoot growth, early stages of rotting, chlorosis and necrosis, which were also observed during the concentration-response experiments conducted in artificial soil. Marchiol et al. (2004), Panda and Choudhury (2005) and Lopez-Luna et al. (2009) confirmed that decreased root length and shoot height with subsequent effect on the overall plant biomass and health are also associated with trivalent chromium toxicity.

The divergence in response amongst species may be associated with differences in seed surface area to volume ratio (Wierzbicka \& Obidzińska, 1998; Boutin et al., 2004); larger-sized seeds tended to be less sensitive to contaminants than smaller-sized seeds. Negative effects of chromium were more pronounced for smaller seeds since they have a greater surface/volume ratio compared to larger seeds, which permits chromium to rapidly penetrate the seed coat prior to its rupture and reach the tissues of the developing embryo. Analogous effects between the surface area to volume ratio and pollutant toxicity have been observed with other organisms, such as insects and fish (Hutchinson et al., 1998; Mason et al., 2000).

The length of chromium exposure to dormant wild seeds was also considered during the concentration-response tests. The dispersion of seeds of such plants usually 
happens in late summer or early fall, but seedlings only appear in the spring. Briefly, there is an interrelation between the two phytohormones naturally present in the dormant embryo: abscisic acid (ABA) and giberrellic acid (GA), particularly cold treatment promotes seed germination by decreasing ABA and increasing GA content (Finch-Savage \& Leubner-Metzger, 2006). Also, the complexity of the seed coat plays an important role when evaluating seed dormancy and germination; the permeability of the seed coat may influence chromium uptake and this affects seed sensitivity to chromium. It has been reported that there is a wide variability in seed coat structure and composition amongst different species (Moïse et al., 2005; Molina et al., 2008; Vishwanath et al., 2013). The composition of hydrophobic cutin and suberin polymers, which are found in the inner and outer layers of the seed coat respectively, defines some of the seed coat barrier properties by controlling the movement of water and solutes into the seed (Molina et al., 2008; Vishwanath et al., 2013). In addition, the presence of pectinaceous mucilage and flavonoids, as well as a number of layers in the seed coat, may impede penetration of various substances from the environment (Moïse et al., 2005). Wierzbicka and Obidzińska (1998) also discovered that the degree of seed coat permeability contributes to the protection of the embryos. In the present study, species with known hard seeds such as A. rosea, D. canadense., H. moscheutos, I. purpurea, S. lycopersicum, T. pratense, M. sativa and Chenopodium album L. (Chenopodiaceae) (Rolston, 1978) demonstrated insensitivity to chromium, especially at the lowest tested concentration $(<$ $250 \mathrm{mg} \mathrm{kg}^{-1}$ ). Hard seeds are defined by having a relatively thick coating made of 
palisade cells. Nevertheless, chromium was able to contaminate the embryo once the thick seed coat was cracked by the emerging radicle.

The upland species were less sensitive to chromium toxicity than the wetland species in the germination test with artificial soil, possibly due to a higher capacity of the wetland species to take up water from the environment and, thus, take up pollutants. Similarly, visible physiological changes, including decreased biomass, wilting and yellowing were detected when Typha domingensis Pers. (Typhaceae) and Spartina alterniflora Loisel. (Poaceae) were exposed to cadmium (Mendelssohn et al., 2001), and when Phalaris arundinacea L. (Poaceae) and Alisma plantago-aquatica L. (Alismataceae) were exposed to elevated zinc levels (Matthews et al., 2005). Alternatively, certain wetland species (e.g. Ceratophyllum demersum L. (Ceratophyllaceae), Elatine triandra Schkuhr. (Elatinaceae) and Phragmites australis (Cav.) Trin. ex. Steud (Poaceae)) displayed a distinctive tolerance to different metals and other pollutants (Zheng et al., 2003; Weis \& Weis, 2004). However, in the contaminated natural seed bank soils no difference in the effect of chromium was found between the wetland and upland species.

In the concentration-response study in artificial soil, it was found that the monocots were more sensitive to chromium toxicity compared to the dicots. Conversely, Shahandeh and Hossner (2000) found that the forb H. annuus was more sensitive than the two grasses, Cynodon dactylon (L.) Pers. (Poaceae) and Panicum virgatum L. (Poaceae), when exposed to trivalent chromium at $0-500 \mathrm{mg} \mathrm{kg}^{-1}$ concentrations. Likewise, monocots were less sensitive than dicots (forbs and woody species) in the seed bank 
study, especially C. canadensis whose number of seedlings did not change much between concentrations compared to P. virgatum and $P$. palustris species grown in artificial soil. Inconsistencies in the germination were observed amongst species belonging to the Poaceae family, especially at the highest CrIII concentrations (>500 $\mathrm{m} \mathrm{kg}^{-1}$ ) with $S$. bicolor $\mathrm{x} S$. sudanense and T. aestivum being affected the most compared to the germination of $A$. sativa, which was only affected at $>4000 \mathrm{mg} \mathrm{kg}^{-1}$ levels of chromium in soil (Lopez-Luna et al., 2009). Also, An (2004) discovered that S. bicolor was more insensitive to cadmium than T. aestivum in terms of both germination and accumulation. Woody species were less sensitive to chromium than grasses and forbs when grown in artificial soil. Previous studies showed that trees like P. banksiana (Gratton et al., 2000), Salix spp., Acer spp. (Sapindaceae), Betula spp., Populus spp. (Salicaceae), and Alnus spp. (Betulaceae) (Pulford \& Watson, 2003) were not only able to withstand metalpolluted environments but could even be considered as potential phytoremediation species, especially when they are growing in the proximity of operating mines and smelters. P. tremuloides from the artificial soil and species from the seed bank soils including $D$. lonicera, $V$. oxycoccos, and $R$. idaeus were insensitive to high (>1000 $\mathrm{mg}$ $\mathrm{kg}^{-1}$ ) levels of chromium than the rest of the tested woody species. Trees have been known to tolerate trace and heavy metals (Robitaille, 1981; Franklin et al., 2002) with the highest accumulation of metals within the ground tissues.

\subsection{Applications to risk assessment}

The present concentration-response study showed that plant traits play a key role in the sensitivity to chromium. Interestingly, herbaceous crops were remarkably more 
tolerant to chromium than the rest of the tested species (Table 4; Appendix 4). Similarly, under controlled greenhouse environments with vanadium (Smith et al., 2013) or rare earth metals (i.e. lanthanum, yttrium and cerium; Thomas et al., 2014, praseodymium, neodymium, samarium, terbium, erbium, and dysprosium; Carpenter et al., 2015), wild species were more susceptible to metal toxicity than crops. Most chromium toxicity studies are focused on agricultural crops due to their economic importance and accessibility, yet agronomic species do not appear to represent wild plants and should be used with caution for ecological monitoring of chromium.

Our results demonstrate striking differences in plant response between a prepared artificial growth medium and natural soils collected during field work. Particularly for the germination experiment in artificial soils, unhealthy seedlings for some plants were observed at the low $\left(250 \mathrm{mg} \mathrm{kg}^{-1}\right)$ chromium concentration and the high $\left(1000 \mathrm{mg} \mathrm{kg}^{-1}\right)$ concentration negatively affected all tested species. On the contrary, no unhealthy seedlings were observed in the natural seed bank soils. In addition, the woody species from the artificial soil were more tolerant to chromium than grasses and forbs, but grasses from the natural soils were less affected by chromium compared to forbs, trees and shrubs. Wetland species selected for the germination test in artificial soil were more sensitive to chromium, but there was no significant difference in response between wetland and upland species from the natural soils; a possible explanation to such divergence in responses is due to types of soils and other metal concentrations, or plants from the natural soils, which may have already developed some tolerance to adverse environmental conditions. 


\subsection{Concluding remarks and future perspectives}

Our results served several purposes: (1) to advance our knowledge of chromium toxicity to wild plants, (2) to provide baseline data for the development of guidelines and monitoring plans important for ecological risk assessments to be conducted near chromite mining sites and other industrial areas that are actively using chromium, and (3) to serve as a reference for future research on the effects of chromium in seed bank soils.

Seed germination and seedling health are often used as the endpoints in toxicological studies conducted with metals (Peralta et al., 2001; Zeid, 2001; Smith et al., 2013; Thomas et al., 2014; Carpenter et al., 2015) or pesticides (Gange et al., 1992; Clark et al., 2004); both germination and health were used in our study. This work also supports previous toxicological literature that chromium is hazardous to plants and environmental contamination arising from chromium mining (i.e. smelting, discharge of waste rock and tailings) in the Ring of Fire may significantly impact not only individual species but plant communities. The effects of chromium on wild terrestrial plants were of a particular concern. This study demonstrated that low levels of chromium $\left(250 \mathrm{mg} \mathrm{kg}^{-1}\right)$ adversely affected the germination of seven species $(22 \%$ of all species tested) from six families (33\% of all families), while higher levels (500 and $1000 \mathrm{mg} \mathrm{kg}^{-1}$ ) affected 22 and 30 species (69\% and 94\%, respectively) from 16 families (89\%). Furthermore, the speed of germination and seedling health were greatly altered by low to medium levels of trivalent chromium. The seed bank study confirmed the effects of chromium on germination of seeds naturally found in soils from the Ring of Fire, although to a lesser extent. In the soils containing low (250 $\left.\mathrm{mg} \mathrm{kg}^{-1}\right)$ and medium $\left(500 \mathrm{mg} \mathrm{kg}^{-1}\right)$ levels of chromium, six 
( $40 \%$ of those that germinated) and seven (47\%) species from six families (50\% of all families) respectively, were negatively affected, while the $1000 \mathrm{mg} \mathrm{kg}^{-1}$ level of chromium affected ten species (67\%) from ten families (83\%). The overall observation of the most sensitive families with multiple representatives showed that some Lamiaceae and Asteraceae species may be negatively affected at levels of chromium as low as 250 $\mathrm{mg} \mathrm{kg}^{-1}$ in soils, and some species of the Brassicaceae, Fabaceae, Pinaceae, Malvaceae, Ericaceae and Rosaceae families may be affected at levels as high as $500 \mathrm{mg} \mathrm{kg}^{-1}$ in soils. Effects observed on a wide range of species and families, used as a proxy for the large spectrum of the plants naturally found in various environments, confirmed the significant impact that chromium may have on plant communities in contaminated sites.

The estimation of chromium effects on seed banks adds a particular uniqueness to this research study. The difference in responses between laboratory and field studies showed that it is difficult to predict toxicity outcomes using plants growing under artificial conditions only. The importance of studying seed banks is not only in identifying the types of species affected by chromium and possible effects on plant communities, but also in detecting how various complex natural factors (e.g. soil attributes and concentrations of other metals) may interfere with chromium. The intolerance of wild plants from seed bank soils should be considered for conservation purposes during mining activities.

The results of this study showed that it may be relevant to address the effects of chromium toxicity on species with varying seed sizes and seed coat permeability. The mechanism of action of chromium on seeds is poorly understood. To this effect, it would 
also be pertinent to assess chromium accumulation in seeds prior to imbibition perhaps via direct application of chromium onto seeds.

Variations in response, with respect to emergence and health, amongst terrestrial plants with differing taxonomic and ecological traits lead to the need for an ecotoxicological approach using a broad range of species. Results of this work showed that chromium toxicity on plants depends on soil characteristics, therefore it would be relevant to test other soils than those included in our study. 


\section{References}

Abreu, M.M., Calouro, F., Fernandes, M.L.V. (2002). Application of chromium to soils at different rates and oxidation states. II. Influence on uptake of selected nutrients by radish. Commun. Soil Sci. Plan. 13 (13\&14), 2269-2277.

Allaie, R.R., Reshi, Z., Rashid, I., Wafai, B.A. (2006). Effect of aqueous leaf leachate of Anthemis cotula -an alien invasive species on germination behaviour of some field crops. J. Argon. Crop Sci. 192, 186-191.

Alloway, B.J. (2013). Heavy metals in soils. Trace metals and metalloids in soils and their bioavailability ( $3^{\text {rd }}$ ed.). Glasgow, UK: Springer.

Amin, H., Arain, B.A., Amin, F., Surhio, M.A. (2013). Phytotoxicity of chromium on germination, growth and biochemical attributes of Hibiscus esculentus L. Am. J. Plant Sci. 4, 2431-2439.

An, Y. (2004). Soil ecotoxicity assessment using cadmium sensitive plants. Environ. Pollut. 127, 21-26.

Appenroth, K., Luther, A., Jetschke, G. Gabrys, H. (2008). Modification of chromate toxicity by sulphate in duckweeds (Lemnaceae). Aquat. Toxicol. 89, 167-171.

Armesto, J.J., Pickett, S.T.A. (1985). Experiments on disturbance in old-field plant communities: impact on species richness and adundance. Ecology 66 (1), 230-240.

Beatrijs, B., Olivier, H. (2008). Can the seed bank be used for ecological restoration? An overview of seed bank characteristics in European communities. J. Veg. Sci. 19, 875-884.

Bluskov, S., Arocena, J.M., Omotoso, O.O., Young, J.P. (2005). Uptake, distribution, and speciation of chromium in Brassica juncea. Int. J. Phytoremediat. 7, 153-165.

Boutin, C., Elmegaard, N., Kjǽr, C. (2004). Toxicity testing of fifteen non-crop plant species with six herbicides in a greenhouse experiment: implications for risk assessment. Ecotoxicology 13, 349-369.

Boutin, C. (2006). Comparison of the vegetation and seedbanks of soybean fields, adjacent boundaries, and hedgerows in Ontario. Can. J. Plant Sci. 86, 557-567.

Brändel, M. (2006). Effect of temperatures on dormancy and germination in three species in the Lamiaceae occurring in northern wetlands. Wetl. Ecol. Manag. 14, 11-28. 
Canadian Council of Ministers of the Environment (CCME). (2015). Canadian soil quality guidelines for the protection of environmental and human health. Retrieved from http://st-ts.ccme.ca/en/index.html [January 15, 2015].

Carpenter, D., Boutin, C., Allison, J.E., Parsons, J.L., Ellis, D.M. (2015). Uptake and effects of six rare earth elements (REEs) on selected native and crop species growing in contaminated soils. PLoS ONE 10(6): 1-21.

Cervantes, C., Campos-Garcia, J., Devars, S., Gutierrez-Corona, F., Loza-Tavera, H., Torres-Guzman, J.C., Moreno-Sanchez, R. (2001). Interactions of chromium with microorganisms and plants. FEMS Microbiol. Rev. 25, 335-347.

Clark, J., Ortego, L.S., Fairbrother, A. (2004). Sources of variability in plant toxicity testing. Chemosphere 57, 1599-1612.

Database of Vascular Plants of Canada (VASCAN). (2015). Plants Database. Retrieved from $\mathrm{http}: / /$ data.canadensys.net/vascan/search [September 15, 2013].

Davies, F.T., Jr., Puryear, J.D., Newton, R.J., Egilla, J.N., Saraiva Grossi, J.A. (2002). Mycorrhizal fungi increase chromium uptake by sunflower plants: influence on tissue mineral concentration, growth, and gas exchange. J.Plant Nutr. 25(11), 2389-2407.

De Flora, S. (2000). Threshold mechanisms and site specificity in chromium (VI) carcinogenesis. Carcinogenesis 21 (4), 533-541.

Dhal, B., Thatoi, H.N., Das, N.N., Pandey, B.D. (2013). Chemical and microbial remediation of hexavalent chromium from contaminated soil and mining/metallurgical solid waste: a review. J. Hazard Mater. 250-251, 272-291.

Environment Canada. (2005). "Biological test method: test for measuring emergence and growth of terrestrial plants exposed to contaminants in soil". Report: EPS 1/RM/45February 2005 (with June 2007 Amendments). Method Development and Applications Section, Environment Technology Centre, Environment Canada.

Environment Canada. (2010). Priority substances list assessment report. Aluminum salts (final content). Retrieved from: https://www.ec.gc.ca/lcpecepa/default.asp?lang=En\&n=491F0099-1\&offset=8 [January 15, 2015].

Environment Canada. (2013). "Biological test method: test for growth in contaminated soil using terrestrial plants native to the boreal region". Report: EPS 1/RM/56-August 2013. Method Development and Applications Section, Science and Technology Branch, Environment Canada. 
Fendorf, S.E. (1995). Surface reactions of chromium in soils and waters. Geoderma 67, $55-71$.

Fernandes, M.L.V., Calouro, F., Abreu, M.M. (2002). Application of chromium to soils at different rates and oxidation states. I. Effect on dry matter yield and chromium uptake by radish. Commun. Soil Sci. Plan. 13 (13\&14), 2259-2268.

Finch-Savage, W.E., Leubner-Metzger, G. (2006). Seed dormancy and the control of germination. New Phytol. 171, 501-523.

Frank, R., Ishida, K., Suda, P. (1976). Metals in agricultural soils of Ontario. Can. J. Soil Sci. 56, 181-196.

Franklin, J.A., Renault, S., Croser, C., Zwiazek, J.J., MacKinnon, M. (2002). Jack pine growth and elemental composition are affected by saline tailings water. J. Environ. Qual. 31, 648-653.

Gange, A.C., Brown, V.K., Farmer, L.M. (1992). Effects of pesticides on the germination of weed seeds: implications for manipulative experiments. J. Appl. Ecol. 29, 303-310.

Gardea-Torresdey, J.L., de la Rosa, G., Peralta-Videa, J.R., Montes, M., Cruz-Jimenez, G., Cano-Aguilera, I. (2005). Differential uptake and transport of trivalent and hexavalent chromium by tumbleweed (Salsola kali). Arch. Environ. Contam. Toxicol. 48, 225-232.

Gill, A., Saggoo, M.I.S. (2010). Mutagenic potential and nutritive quality of turnip plants raised over chromium amended soils. Int. J. Botany 6(2), 127-131.

Gleason, H.A., Cronquist, A. (1991). Manual of vascular plants of northeastern United States and adjacent Canada ( $2^{\text {nd }}$ ed.). Bronx, NY: The New York Botanical Garden Press.

Gratton, W.S., Nkongolo, K.K., Spiers, G.A. (2000). Heavy metal accumulation in soil and jack pine (Pinus banksiana) needles in Sudbury, Ontario, Canada. B. Environ. Contam. Tox. 64, 550-557.

Harper, J.L. (1977). Population biology of plants. New York, NY: Academic Press Inc.

Honda, Y. (2008). Ecological correlations between the persistence of the soil seed bank and several plant traits, including seed dormancy. Plant Ecol. 196, 301-309.

Hooper, D.U., Chapin, F.S., III, Ewel, J.J., Hector, A., Inchausti, P., Lavorel, S., Lawton, J.H., Lodge, D.M., Loreau, M., Naeem, S., Schmid, B., Setälä, H., Symstad, A.J., Vandermeer, J., Wardle, D.A. (2005). Effects of biodiversity on ecosystem functioning: a consensus of current knowledge. Ecol. Monogr. 75(1), 3-35. 
Huffman, E.W.D., Jr., Allaway, W.H. (1973). Growth of plants in solution culture containing low levels of chromium. Plant Physiol. 52, 72-75.

Hutchinson, T.H., Solbé, J., Kloepper-Sams, P.J. (1998). Analysis of the ecetoc aquatic toxicity (EAT) database III-comparative toxicity of chemical substances to different life stages of aquatic organisms. Chemosphere 36(1), 129-142.

Iman, R.L., Conover, W.J. (1987). A measure of top-down correlation. Technometrics 29(3), 351-357.

International Chromium Development Association (ICDA). (2011). Mining. Discover chromium. Retrieved from:

http://www.icdacr.com/index.php?option=com_content\&view=article\&id=158:discoverchrome-mining\&catid $=66 \&$ lang=en [February 15, 2015].

Kabata-Pendias, A. (2011). Trace elements in soils and plants ( $4^{\text {th }}$ ed.). Boca Raton, FL: CRC Press.

Kanbar, H.J., Hanna, N., El Samrani, A.G., Kazpard, V., Kobaissi, A., Harb, N., Amacha, N. (2014). Metal binding in soil cores and sediments in the vicinity of a dammed agricultural and industrial watershed. Environ. Monit. Assess. 186, 8793-8806

Katz, S.A., Salem, H. (1994). The biological and environmental chemistry of chromium. New York, NY: VCH Publishers Inc.

Khan, N., Mishra, A., Chauhan, P.S., Sharma, Y.K., Nautiyal, C.S. (2012). Paenibacillus lentimorbus enhances growth of chickpea (Cicer arietinum L.) in chromium-amended soil. A. Van Leeuw. J. Microb. 101, 453-459.

Klimkowska, A., Bekker, R.M., Van Diggelen, R., Kotowski, W. (2010). Species trait shifts in vegetation and soil seed bank during fen degradation. Plant Ecol. 206, 59-82.

Knox, J.S. (1997). A nine year demographic study of Helenium virginicum (Asteraceae), a narrow endemic seasonal wetland plant. J. Torrey Bot. Soc. 124 (3), 236-245.

Kotas, J., Stasicka, Z. (2000). Chromium occurrence in the environment and methods of its speciation. Environ. Pollut. 107, 263-283.

Kranner, I., Colville, L. (2011). Metals and seeds: biochemical and molecular implications and their significance for seed germination. Environ. Exp. Bot. 72, 93-105. 
Labra, M., Gianazza, E., Waitt, R., Eberini, I., Sozzi, A., Regondi, S., Grassi, F., Agradi, E. (2006). Zea mays L. protein changes in response to potassium dichromate treatments. Chemosphere 62, 1234-1244.

Lahouti, M., Peterson, P.J. (1979). Chromium accumulation and distribution in crop plants. J. Sci. Food Agr. 30, 136-142.

Liu, J., Duan, C., Zhang, X., Zhu, Y., Hu, C. (2011). Characteristics of chromium (III) uptake in hyperaccumulator Leersia hexandra Swartz. Environ. Exp. Bot. 74, 122-126.

Lopez-Luna, J., Gonzalez-Chavez, M.C., Esparza-Garcia, F.J., Rodriguez-Vazquez, R. (2009). Toxicity assessment of soil amended with tannery sludge, trivalent chromium, and hexavalent chromium, using wheat, oat and sorghum plants. J. Hazard Mater. 163, 829-834.

Lukaski, H.C. (1999). Chromium as a supplement. Annu. Rev. Nutr. 19, 279-302.

Matthews, D.J., Moran, B.M., Otte, M.L. (2005). Screening the wetland plant species Alisma plantago-aquatica, Carex rostrata and Phalaris arundinacea for innate tolerance to zinc and comparison with Eriophorum angustifolium and Festuca rubra Merlin. Environ. Pollut. 134, 343-351.

Marchiol, L., Assolari, S., Sacco, P., Zerbi, G. (2004). Phytoextraction of heavy metals by canola (Brassica napus) and radish (Raphanus sativus) grown on multicontaminated soil. Environ. Pollut. 132, 21-27.

Marti, E., Sierra, J., Sanchez, M., Cruanas, R., Garau, M.A. (2007). Ecotoxicological tests assessment of soil polluted by chromium (VI) or pentachlorophenol. Sci. Total Environ. 378, 53-57.

Mason, R.P., Laporte, J.M., Andres, S. (2000). Factors controlling the bioaccumulation of mercury, methylmercury, arsenic, selenium, and cadmium by freshwater invertebrates and fish. Arch. Environ. Con. Tox. 38, 283-297.

McKeague, J.A., Wolynetz, M.S. (1980). Background levels of minor elements in some Canadian soils. Geoderma 24, 299-307.

Mendelssohn, I.A., McKee, K.L., Kong, T. (2001). A comparison of physiological indicators of sublethal cadmium stress in wetland plants. Environ. Exp. Bot. 46, 263-275.

Moïse, J.A., Han, S., Gudynaite-Savitch, L., Johnson, D.A., Miki, B.L.A. (2005). Seed coats: structure, development, composition, and biotechnology. In Vitro Cell. Dev. B. $41,620-644$. 
Molina, I., Ohlrogge, J.B., Pollard, M. (2008). Deposition and localization of lipid polyester in developing seeds of Brassica napus and Arabidopsis thaliana. Plant J. 53, 437-449.

Moral, R., Gomez, I., Pedreno, J.N., Mataix, J. (1996). Absorption of Cr and effects of micronutrient content in tomato plant (Lycopersicum esculentum M.). Agrochimica, 40 (2-3), 132-138.

Norberg-King, T.J. (1993). A linear interpolation method for sublethal toxicity: the inhibition concentration (ICp) approach (version 2.0). Technical Report 03-93. United States Environmental Protection Agency, Environmental Research Laboratory, Duluth, MN.

Notten, M.J.M., Oosthoek, A.J.P., Rozema, J., Aerts, R. (2005). Heavy metal concentrations in a soil-plant-snail food chain along a terrestrial soil pollution gradient. Environ. Pollut. 138, 178-190.

O’Flaherty, E.J., Kerger, B.D., Hays, S.M., Paustenbach, D.J. (2001). A physiologically based model for the ingestion of chromium (III) and chromium (VI) by humans. Toxicol. Sci. 60, 196-213.

Oldham, M.J., Bakowsky, W.D., Sutherland, D.A. (1995). Floristic quality assessment system for Southern Ontario. Natural Heritage Information Centre, Ontario Ministry of Natural Resources, Peterborough, Ontario, Canada.

Olszyk, D., Pfleeger, T., Henry Lee, E., Burdick, C., King, G., Plocher, M., Kern, J. (2008). Selecting and evaluating native plants for region-specific phytotoxicity testing. Integ. Environ. Assess. Manag. 4(1), 105-117.

Organisation for Economic Co-operation and Development (OECD). (2006). Current approaches in the statistical analysis of ecotoxicity data: a guidance to application (No. 54). OECD Series on Testing and Assessment, Paris.

Palmer, C.D., Wittbrodt, P.R. (1991). Processes affecting the remediation of chromiumcontaminated sites. Environ. Health Persp. 92, 25-40.

Panda, S.K., Choudhury, S. (2005). Chromium stress in plants. Braz. J. Plant Physiol. 17(1), 95-102.

Pandey, V., Dixit, V., Shyam, R. (2009). Chromium (VI) induced changes in growth and root plasma membrane redox activities in pea plants. Protoplasma 235, 49-55.

Papp, J.F. (2003). Chromium. U.S. Geological survey minerals yearbook, 17.1-17.22. 
Parr, P.D., Taylor, F.G., Jr. (1982). Germination and growth effects of hexavalent chromium in Orocol TL (a corrosion inhibitor) on Phaseolus vulgaris. Environ. Int. 7 , 197-202.

Pawlisz, A.V., Kent, R.A., Schneider, U.A., Jefferson, C. (1997). Canadian water quality guidelines for chromium. Environ. Toxic. Water 12, 185-193.

Peng, J., Song, Y., Yuan, P., Cui, X., Qiu, G. (2009). The remediation of heavy metals contaminated sediment. J. Hazard. Mater. 161, 633-640.

Peralta-Videa, J.R., Lopez, M.L., Narayan, M., Saupe, G., Gardea-Torresdey, J. (2009). The biochemistry of environmental heavy metal uptake by plants: implications for the food chain. Int. J. Biochem. Cell B. 41, 1665-1677.

Peralta, J.R., Gardea-Torresdey, J.L., Tiemann, K.J., Gomez, E., Arteaga, S., Rascon, E., Parsons, J.G. (2001). Uptake and effects of five heavy metals on seed germination and plant growth in alfalfa (Medicago sativa L.). B. Environ. Contam. Tox. 66, 727-734.

Potts, S.G., Biesmeijer, J.C., Kremen, C., Neumann, P., Schweiger, O., Kunin, W.E. (2010). Global pollinator declines: trends, impacts and drivers. Trends Ecol. Evol. 25(6): $345-353$.

Prasad, A., Singh, A.K., Chand, S., Chanotiya, C.S., Patra, D.D. (2010). Effect of chromium and lead on yield, chemical composition of essential oil, and accumulation of heavy metals of mint species. Commun. Soil Sci. Plan. 41, 2170-2186.

Pulford, I.D., Watson, C. (2003). Phytoremediation of heavy metal-contaminated land by trees-a review. Environ. Int. 29, 529-540.

Rai, D., Eary, L.E., Zachara, J.M. (1989). Environmental chemistry of chromium. Sci. Total Environ. 86, 15-23.

Reid, K. (1998). Soil fertility handbook. Ministry of Agriculture, food and rural affairs. OMAFRA. Retrieved from: www.omafra.gov.on.ca/english/crops/pub611/p611order.pdf [July 31, 2015].

Rhoades, J.D. (1982). Cation exchange capacity: methods of soil analysis $\left(2^{\text {nd }}\right.$ ed. $)$. Agronomy 9 (pp. 149-157). Madison, WI: American Society of Agronomy Inc.

Robitaille, G. (1981). Heavy-metal accumulation in the annual rings of balsam fir Abies balsamea (L.) Mill. Environ. Pollut. 2, 193-202.

Rolston, M.P. (1978). Water impermeable seed dormancy. Bot. Rev. 44 (3), 365-396. 
Rossmann, R., Barres, J. (1988). Trace element concentrations in near-surface waters of the Great Lakes and methods of collection, storage, and analysis. J. Great Lakes Res. 14(2), 188-204.

Schmidt, W. (1996). Influence of chromium (III) on root-associated Fe(III) reductase in Plantago lanceolata L. J. Exp. Bot. 47(299), 805-810.

Scoccianti, V., Crinelli, R., Tirillini, B., Mancinelli, V., Speranza, A. (2006). Uptake and toxicity of $\mathrm{Cr}(\mathrm{III})$ in celery seedlings. Chemosphere 64, 1695-1703.

Shahandeh, H., Hossner, L.R. (2000). Plant screening for chromium phytoremediation.

Int. J. Phytoremediat. 2(1), 31-51.

Sharma, A.D., Brar, M.S., Malhi, S.S. (2005). Critical toxic ranges of chromium in spinach plants and in soil. J. Plant Nutr. 28, 1555-1568.

Sheldrick, B.H., Wang, C. (1993). Particle size distribution: soil sampling and methods of analysis. In M.R. Carter (Ed.), Canadian society of soil sciences (pp. 499-507). Boca Raton, FL: CRC Press.

Sinha, S., Saxena, R., Singh, S. (2005). Chromium induced lipid peroxidation in the plants of Pistia stratiotes L.: role of antioxidants and antioxidant enzymes. Chemosphere $58,595-604$.

Skeffington, R.A., Shewry, P.R., Peterson, P.J. (1976). Chromium uptake and transport in barley seedlings (Hordeum vulgare L.). Planta 132, 209-214.

Smith, P.G., Boutin, C., Knopper, L. (2013). Vanadium pentoxide phytotoxicity: effects of species selection and nutrient concentration. Arch. Environ. Con. Tox. 64, 87-96.

Srivastava, S., Prakash, S., Srivastava, M.M. (1999). Chromium mobilization and plant availability - the impact of organic complexing ligands. Plant Soil 212, 203-208.

Stasinos, S., Zabetakis, I. (2013). The uptake of nickel and chromium from irrigation water by potatoes, carrots and onions. Ecotox. Environ. Safe. 91, 122-128.

Thomas, P.J., Carpenter, D., Boutin, C., Allison, J.E. (2014). Rare earth elements (REEs): effects on germination and growth of selected crop and native plant species.

Chemosphere 96, 57-66.

Tiessen, H., Moir, J.O. (1993). Total and organic carbon: soil sampling and methods of analysis. In M.R. Carter (Ed.), Canadian society of soil sciences (pp. 190-191). Boca Raton, FL: CRC Press. 
U.S. Environmental Protection Agency. (1983). Method 350.1 - Methods for chemical analysis of water and wastes. Retrieved from http://www.state.in.us/dnr/fishwild/files/Methods_Analysis_Water_Wastes_USEPA_Mar ch1983.pdf [July 31, 2015].

U.S. Environmental Protection Agency. (1993). Method 353.2 - Methods for the determination of inorganic substances in environmental samples. Retrieved from monitoringprotocols.pbworks.com/f/EPA600-R-63-100.pdf [July, 31, 2015].

U.S. Environmental Protection Agency. (1994). Method 200.8 - Determination of trace elements in waters and wastes by inductively coupled plasma-mass spectrometry. Retrieved from http://www.epa.gov/sam/pdfs/EPA-200.8.pdf [June 10, 2014].

U.S. Environmental Protection Agency. (1994). Method 200.7 - Determination of metals and trace elements in water and wastes by inductively coupled plasma-atomic emission spectrometry. Retrieved from http://www.epa.gov/sam/pdfs/EPA-200.7.pdf [January 15, 2015].

U.S. Environmental Protection Agency. (1996). Method 3050B - Acid digestion of sediments, sludges, and soils. Retrieved from http://www.epa.gov/sam/pdfs/EPA3050b.pdf [November 12, 2014].

U.S. Environmental Protection Agency. (2001). Method 245.5 - Mercury in sediments by manual cold vapor atomic absorption (CVAA). Retrieved from http://www.epa.gov/region9/qa/pdfs/245_5dqi.pdf [January 15, 2015].

United States Department of Agriculture (USDA). (2015). Plants Database. Retrieved from http://www.plants.usda.gov/java/ [September 15, 2013].

Vishwanath, S.J., Kosma, D.K., Pulsifer, I.P., Scandola, S., Pascal, S., Joubes, J., Dittrich-Domergue, F., Lessire, R., Rowland, O., Domergue,F. (2013). Suberinassociated fatty alcohols in Arabidopsis: distributions in roots and contributions to seed coat barrier properties. Plant Physiol. 163, 1118-1132.

Warr, S.J., Thompson, K., Kent, M. (1993). Seed banks as a neglected area of biogeographic research: a review of literature and sampling techniques. Prog. Phys. Geog. 17 (3), 329-347.

Weis, J.S., Weis, P. (2004). Metal uptake, transport and release by wetland plants: implications for phytoremediation and restoration. Environ. Int. 30, 685-700. 
White, A.L., Boutin, C., Dalton, R.L., Henkelman, B, Carpenter, D. (2009). Germination requirements for 29 terrestrial and wetland wild plant species appropriate for phytotoxicity testing. Pest. Manag. Sci. 65, 19-26.

Wierzbicka, M., Obidzińska, J. (1998). The effect of lead on seed imbibition and germination in different plant species. Plant Sci. 137, 155-171.

World Health Organization (WHO). (2003). Chromium in drinking-water. Background document for development of WHO guidelines for drinking-water quality, Geneva. Retrieved from http://www.who.int/water_sanitation_health/publications/chromium/en/ [October 15, 2013].

Zayed, A.M., Terry, N. (2003). Chromium in the environment: factors affecting biological remediation. Plant Soil 249, 139-156.

Zayed, A., Mel Lytle, C., Qian, J., Terry, N. (1998). Chromium accumulation, translocation and chemical speciation in vegetable crops. Planta 206, 293-299.

Zeid, I.M. (2001). Responses of Phaseolus vulgaris to chromium and cobalt treatments. Biol. Plantarum 44(1), 111-115.

Zheng, J., Hintelmann, H., Dimock, B., Dzurko, M.S. (2003). Speciation of arsenic in water, sediment, and plants of the Moira watershed, Canada, using HPLC coupled to high resolution ICP-MS. Anal. Bioanal. Chem. 377, 14-24.

Zou, J.H., Wang, M., Jiang, W.S., Liu, D.H. (2006). Effects of hexavalent chromium (VI) on root growth and cell division in root tip cells of Amaranthus viridis L. Pak. J. Bot. 38(3), 673-681. 
Appendix 1: Levels of 28 metals (in $\mathrm{mg} \mathrm{kg}^{-1}$ ) in the artificial soil used for the concentration-response experiment (chemical analyses were performed by the RPC laboratory, RPC, New Brunswick). Reporting limit [RL] refers to a minimum amount of analytes detected and measured within the soil medium. The average natural levels of metals in the worldwide soils (obtained from several literature sources) and the soil quality guidelines (obtained from the "Soil Quality Guidelines for the Protection of Environmental and Human Health". Ontario: Canadian Council of Ministers of the Environment, CCME, 2015, via http://st-ts.ccme.ca/en/index.html) are presented.

\begin{tabular}{|c|c|c|c|c|c|c|c|c|}
\hline \multicolumn{6}{|c|}{ Natural levels } & \multirow[t]{2}{*}{ CCME } & \multicolumn{2}{|l|}{ Measured levels } \\
\hline Metals & & Min & Max & Mean & Reference & & (Average of 25 control samples) & RL \\
\hline Aluminum & $\mathrm{Al}$ & 12000 & 87633 & 41475 & Environment Canada, 2010 & - & 5678.29 & 1 \\
\hline Antimony & $\mathrm{Sb}$ & 0.25 & 1.04 & 0.67 & Kabata-Pendias, 2011 & 20 & 0.1 & 0.1 \\
\hline Arsenic & As & 0.1 & 67 & 6.83 & Kabata-Pendias, 2011 & 12 & 1 & 1 \\
\hline Barium & $\mathrm{Ba}$ & 362 & 580 & - & Kabata-Pendias, 2011 & 750 & 46.37 & 1 \\
\hline Beryllium & $\mathrm{Be}$ & 0.92 & 2 & - & Kabata-Pendias, 2011 & 4 & 0.21 & 0.1 \\
\hline Bismuth & $\mathrm{Bi}$ & - & - & 0.42 & Kabata-Pendias, 2011 & - & 1 & 1 \\
\hline Boron & $\mathrm{B}$ & 10 & 100 & 42 & Kabata-Pendias, 2011 & 2 & 1.12 & 1 \\
\hline Cadmium & $\mathrm{Cd}$ & 0.22 & 1.1 & 0.41 & Kabata-Pendias, 2011 & 1.4 & 0.09 & 0.01 \\
\hline Chromium & $\mathrm{Cr}$ & 10 & 100 & 60 & Kabata-Pendias, 2011 & 64 & 5.1 & 1 \\
\hline Cobalt & $\mathrm{Co}$ & - & - & 8 & Kabata-Pendias, 2011 & 40 & 0.21 & 0.1 \\
\hline Copper & $\mathrm{Cu}$ & 14 & 109 & 38.9 & Kabata-Pendias, 2011 & 63 & 1.2 & 1 \\
\hline Iron & $\mathrm{Fe}$ & 2560 & 38900 & 14470 & Frank et al., 1976 & - & 488.29 & 20 \\
\hline Lead & $\mathrm{Pb}$ & 3 & 90 & 27 & Kabata-Pendias, 2011 & 70 & 10.06 & 0.1 \\
\hline Lithium & $\mathrm{Li}$ & 13 & 28 & - & Kabata-Pendias, 2011 & - & 1.48 & 0.1 \\
\hline Manganese & $\mathrm{Mn}$ & 411 & 550 & - & Kabata-Pendias, 2011 & - & 5.37 & 1 \\
\hline Mercury & $\mathrm{Hg}$ & 0.58 & 1.8 & 1.1 & Kabata-Pendias, 2011 & 6.6 & 0.02 & 0.01 \\
\hline
\end{tabular}




\begin{tabular}{ccccclccc} 
Molybdenum & $\mathrm{Mo}$ & 0.9 & 1.8 & 1.1 & Kabata-Pendias, 2011 & 5 & 0.26 & 1 \\
Nickel & $\mathrm{Ni}$ & 13 & 37 & - & Kabata-Pendias, 2011 & 50 & 0.1 \\
Rubidium & $\mathrm{Rb}$ & 100 & 120 & 50 & Kabata-Pendias, 2011 & - & 0.69 & 1 \\
Selenium & $\mathrm{Se}$ & 0.05 & 1.5 & 0.44 & Kabata-Pendias, 2011 & 1 & 1 & 0.1 \\
Silver & $\mathrm{Ag}$ & 0.05 & 0.13 & - & Kabata-Pendias, 2011 & 20 & 22.68 & 0.1 \\
Strontium & $\mathrm{Sr}$ & 130 & 240 & - & Kabata-Pendias, 2011 & - & 0.1 & 1 \\
Tellurium & $\mathrm{Te}$ & 0.02 & 0.69 & - & Kabata-Pendias, 2011 & - & 0.1 & 0.1 \\
Thallium & $\mathrm{Tl}$ & 0.85 & 1 & 0.5 & Kabata-Pendias, 2011 & 1 & 1 & 0.1 \\
Tin & $\mathrm{Ti}$ & 0.1 & 5 & 2.5 & Kabata-Pendias, 2011 & 5 & 8.4 & 1 \\
Uranium & $\mathrm{U}$ & 0.79 & 11.9 & - & Alloway, 2013 & 23 & 3.17 & 1 \\
Vanadium & $\mathrm{V}$ & 69 & 320 & 129 & Kabata-Pendias, 2011 & 130 & 7.71 & 1 \\
Zinc & $\mathrm{Zn}$ & 60 & 89 & - & Kabata-Pendias, 2011 & 200 & & \\
\hline
\end{tabular}


Appendix 2: Levels of 28 metals (in $\mathrm{mg} \mathrm{kg}^{-1}$ ) in the seed bank soil samples from four sites (i.e. Bucheski Lake, upland, wetland, and Winisk River) in Nibinamik traditional/reserve land, Ontario (chemical analyses were performed by the RPC laboratory, RPC, New Brunswick). Reporting limit [RL] refers to a minimum amount of analytes detected and measured within the soil medium. The average natural levels of metals in the worldwide soils (obtained from several literature sources) and the soil quality guidelines (obtained from the "Soil Quality Guidelines for the Protection of Environmental and Human Health". Ontario: Canadian Council of Ministers of the Environment, CCME, 2015, via http://st-ts.ccme.ca/en/index.html) are presented.

\begin{tabular}{|c|c|c|c|c|c|c|c|c|c|c|c|}
\hline \multicolumn{6}{|c|}{ Natural concentrations } & \multirow[t]{2}{*}{ CCME } & \multicolumn{5}{|c|}{ Measured levels } \\
\hline Metals & & Min & $\operatorname{Max}$ & Mean & Reference & & Lake & Upland & Wetland & River & RL \\
\hline Aluminum & $\mathrm{Al}$ & 12000 & 87633 & 41475 & Environment Canada, 2010 & - & 9970 & 12200 & 307 & 14200 & 1 \\
\hline Antimony & $\mathrm{Sb}$ & 0.25 & 1.04 & 0.67 & Kabata-Pendias, 2011 & 20 & 0.1 & 0.1 & 0.1 & 0.1 & 0.1 \\
\hline Arsenic & As & 0.1 & 67 & 6.83 & Kabata-Pendias, 2011 & 12 & 3.5 & 2 & 1 & 16 & 1 \\
\hline Barium & $\mathrm{Ba}$ & 362 & 580 & - & Kabata-Pendias, 2011 & 750 & 11.5 & 20 & 16 & 110 & 1 \\
\hline Beryllium & $\mathrm{Be}$ & 0.92 & 2 & - & Kabata-Pendias, 2011 & 4 & 0.3 & 0.2 & 0.1 & 0.5 & 0.1 \\
\hline Bismuth & $\mathrm{Bi}$ & - & - & 0.42 & Kabata-Pendias, 2011 & - & 1 & 1 & 1 & 1 & 1 \\
\hline Boron & $\mathrm{B}$ & 10 & 100 & 42 & Kabata-Pendias, 2011 & 2 & 1 & 1 & 9 & 7 & 1 \\
\hline Cadmium & $\mathrm{Cd}$ & 0.22 & 1.1 & 0.41 & Kabata-Pendias, 2011 & 1.4 & 0.03 & 0.04 & 0.2 & 0.14 & 0.01 \\
\hline Chromium & $\mathrm{Cr}$ & 10 & 100 & 60 & Kabata-Pendias, 2011 & 64 & 29 & 36 & 4 & 34 & 1 \\
\hline Cobalt & $\mathrm{Co}$ & - & - & 8 & Kabata-Pendias, 2011 & 40 & 7.3 & 5.8 & 0.2 & 10.1 & 0.1 \\
\hline Copper & $\mathrm{Cu}$ & 14 & 109 & 38.9 & Kabata-Pendias, 2011 & 63 & 10.5 & 9 & 1 & 10 & 1 \\
\hline Iron & $\mathrm{Fe}$ & 2560 & 38900 & 14470 & Frank et al., 1976 & - & 14950 & 18000 & 360 & 21300 & 20 \\
\hline Lead & $\mathrm{Pb}$ & 3 & 90 & 27 & Kabata-Pendias, 2011 & 70 & 4.05 & 4.6 & 5.5 & 12.3 & 0.1 \\
\hline Lithium & $\mathrm{Li}$ & 13 & 28 & - & Kabata-Pendias, 2011 & - & 13.05 & 17.7 & 0.1 & 20.3 & 0.1 \\
\hline Manganese & $\mathrm{Mn}$ & 411 & 550 & - & Kabata-Pendias, 2011 & - & 211.5 & 121 & 54 & 2270 & 1 \\
\hline Mercury & $\mathrm{Hg}$ & 0.58 & 1.8 & 1.1 & Kabata-Pendias, 2011 & 6.6 & 0.01 & 0.01 & 0.07 & 0.07 & 0.01 \\
\hline
\end{tabular}




\begin{tabular}{ccccclccccccc} 
Molybdenum & $\mathrm{Mo}$ & 0.9 & 1.8 & 1.1 & Kabata-Pendias, 2011 & 5 & 0.1 & 0.2 & 0.3 & 0.3 & 0.1 \\
Nickel & $\mathrm{Ni}$ & 13 & 37 & - & Kabata-Pendias, 2011 & 50 & 22 & 32 & 1 & 21 & 1 \\
Rubidium & $\mathrm{Rb}$ & 100 & 120 & 50 & Kabata-Pendias, 2011 & - & 8.6 & 6.7 & 2.2 & 26 & 0.1 \\
Selenium & $\mathrm{Se}$ & 0.05 & 1.5 & 0.44 & Kabata-Pendias, 2011 & 1 & 1 & 1 & 1 & 1 \\
Silver & $\mathrm{Ag}$ & 0.05 & 0.13 & - & Kabata-Pendias, 2011 & 20 & 0.1 & 0.1 & 0.1 & 0.1 & 0.1 \\
Strontium & $\mathrm{Sr}$ & 130 & 240 & - & Kabata-Pendias, 2011 & - & 8 & 6 & 21 & 25 & 1 \\
Tellurium & $\mathrm{Te}$ & 0.02 & 0.69 & - & Kabata-Pendias, 2011 & - & 0.1 & 0.1 & 0.1 & 0.1 & 0.1 \\
Thallium & $\mathrm{Tl}$ & 0.85 & 1 & 0.5 & Kabata-Pendias, 2011 & 1 & 0.1 & 0.1 & 0.1 & 0.1 & 0.1 \\
Tin & $\mathrm{Ti}$ & 0.1 & 5 & 2.5 & Kabata-Pendias, 2011 & 5 & 1 & 1 & 1 & 1 \\
Uranium & $\mathrm{U}$ & 0.79 & 11.9 & - & Alloway, 2013 & 23 & 0.5 & 0.3 & 0.1 & 0.1 & 0.1 \\
Vanadium & $\mathrm{V}$ & 69 & 320 & 129 & Kabata-Pendias, 2011 & 130 & 23.5 & 35 & 1 & 35 & 1 \\
Zinc & $\mathrm{Zn}$ & 60 & 89 & - & Kabata-Pendias, 2011 & 200 & 26.5 & 30 & 28 & 53 & 1 \\
\hline
\end{tabular}


Appendix 3: Average total percent germination for healthy seedlings [green bars] and for unhealthy seedlings [red bars], as well as average speed of seed germination [dashed line] for non-stratified/stratified seeds grown in soils contaminated with increasing levels of chromium (CrIII). All 32 species (non-stratified) were exposed to chromium for one month during the concentration-response experiment in the growth chambers. All nine species (stratified) were exposed to chromium during a four to eight week stratification period (Table 1) in a dark refrigerator at $4{ }^{0} \mathrm{C}$, as well as for a one month concentrationresponse experiment in the growth chambers. Percent germination and speed of germination decreased with increasing CrIII concentrations $\left(0-1000 \mathrm{mg} \mathrm{kg}^{-1}\right)$ in artificial soil. Error bars represent standard errors. Axes for both percent germination and speed of germination vary amongst the tested species.

\section{A. balsamea (Non-stratified)}

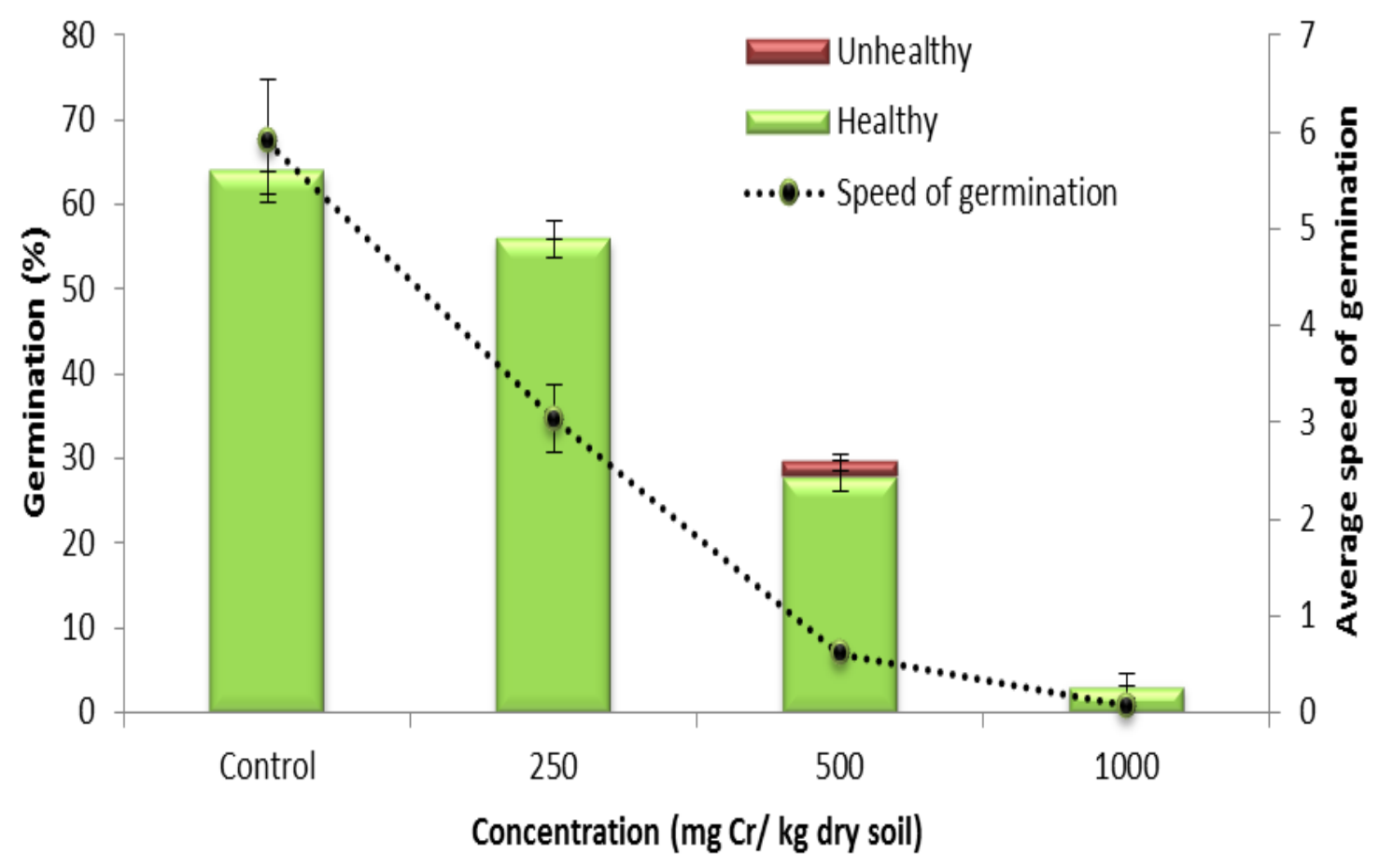


A. balsamea (Stratified)

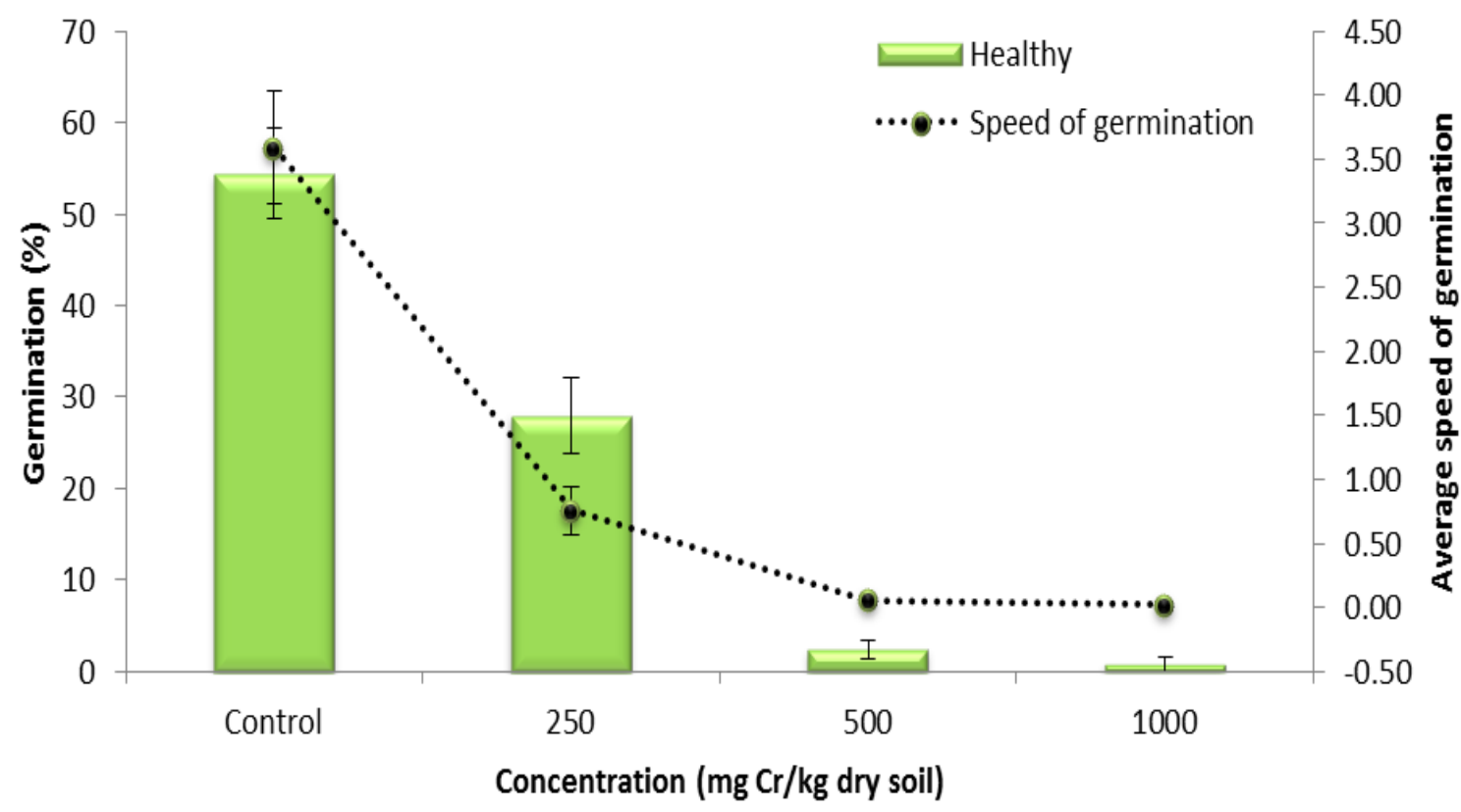

P. mariana (Non-stratified)

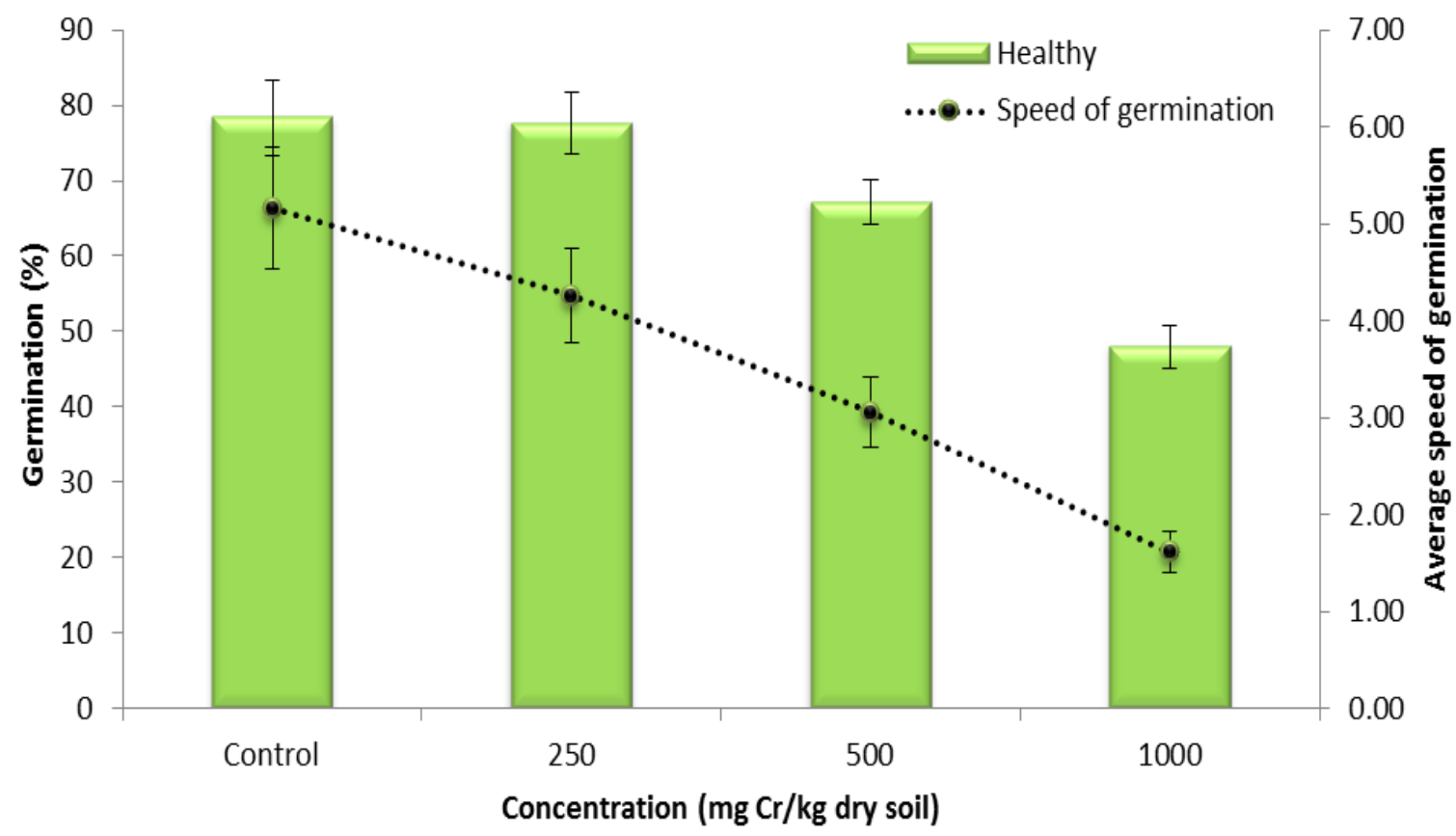


P. mariana (Stratified)

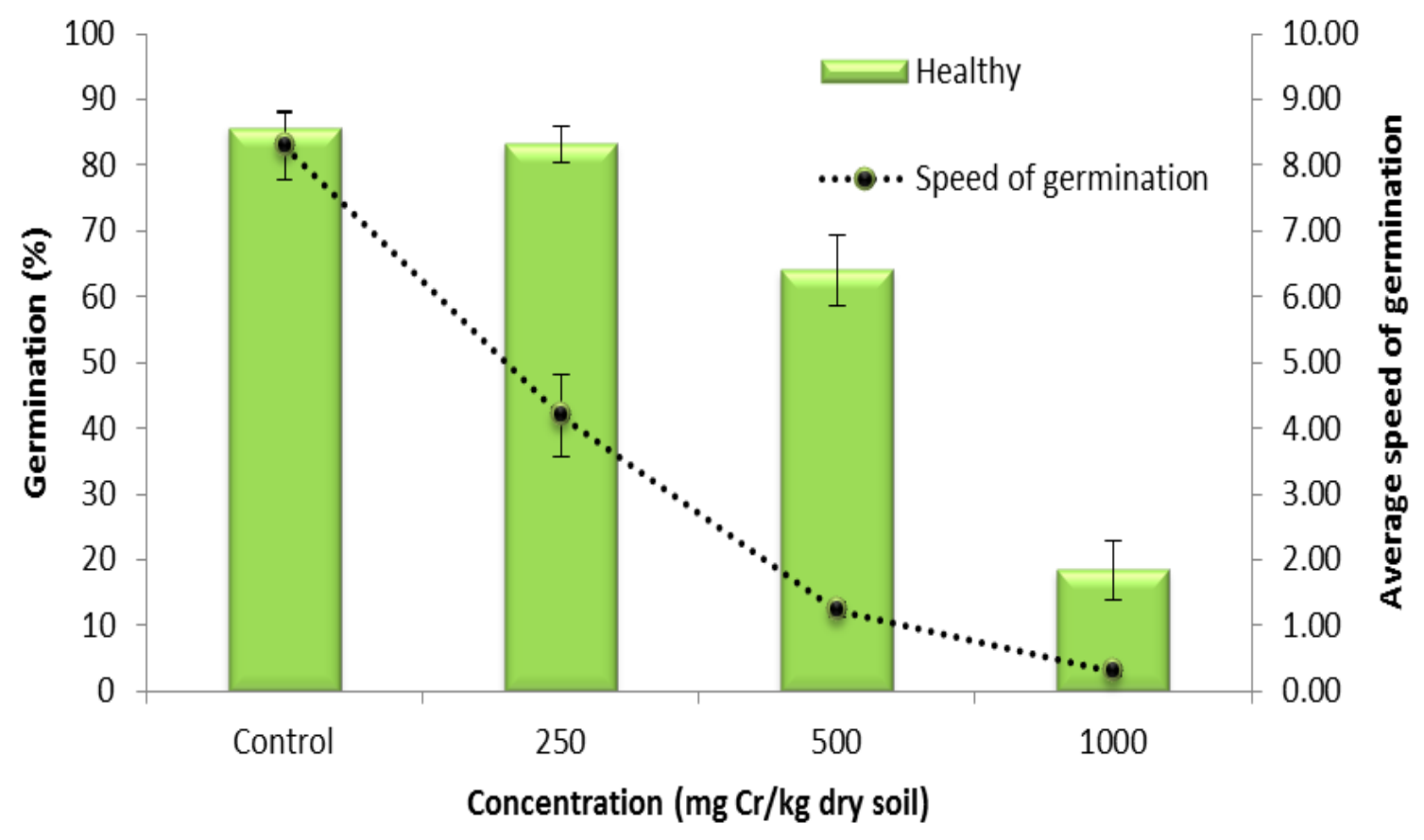

P. banksiana (Non-stratified)

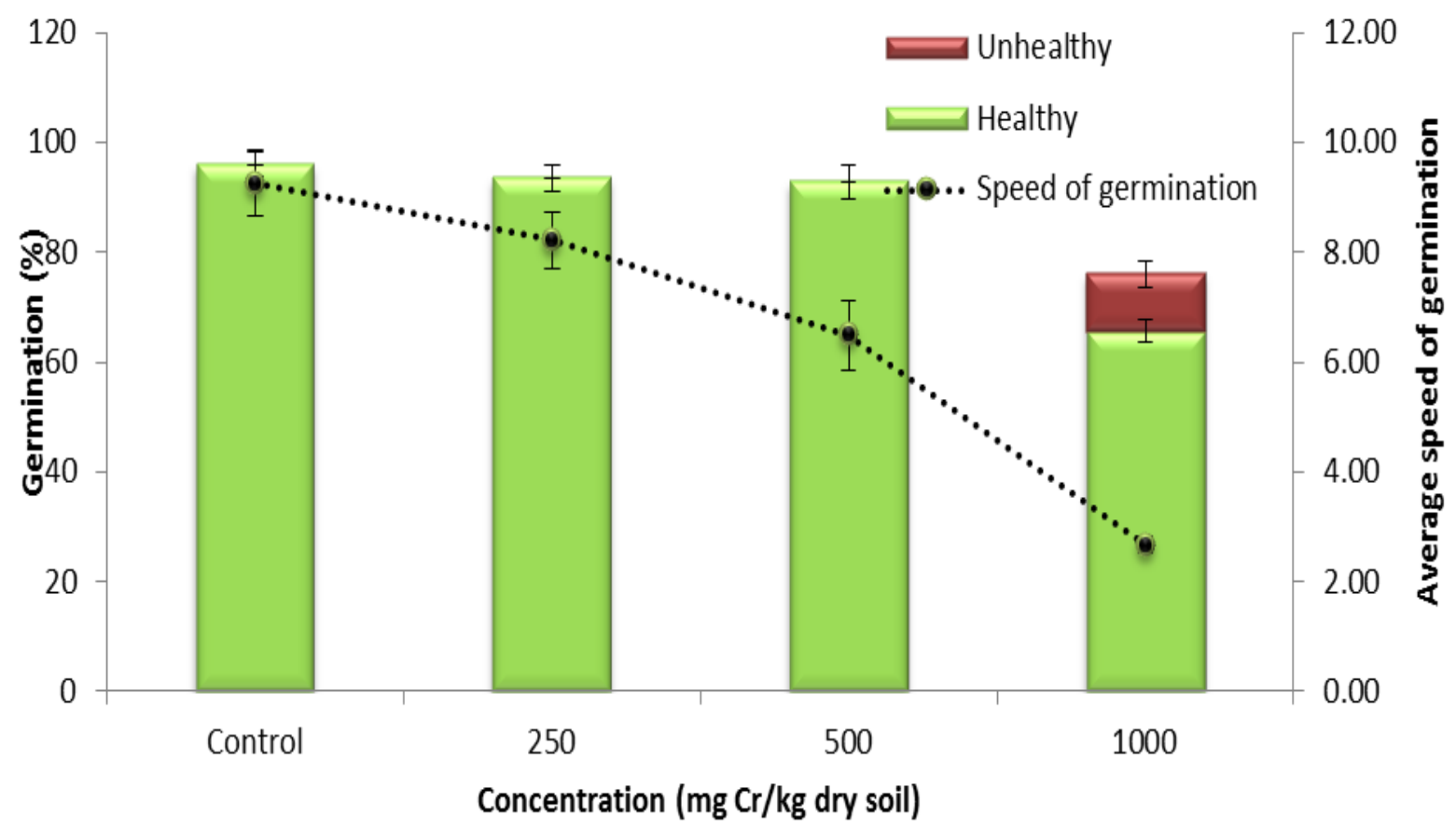


P. banksiana (Stratified)

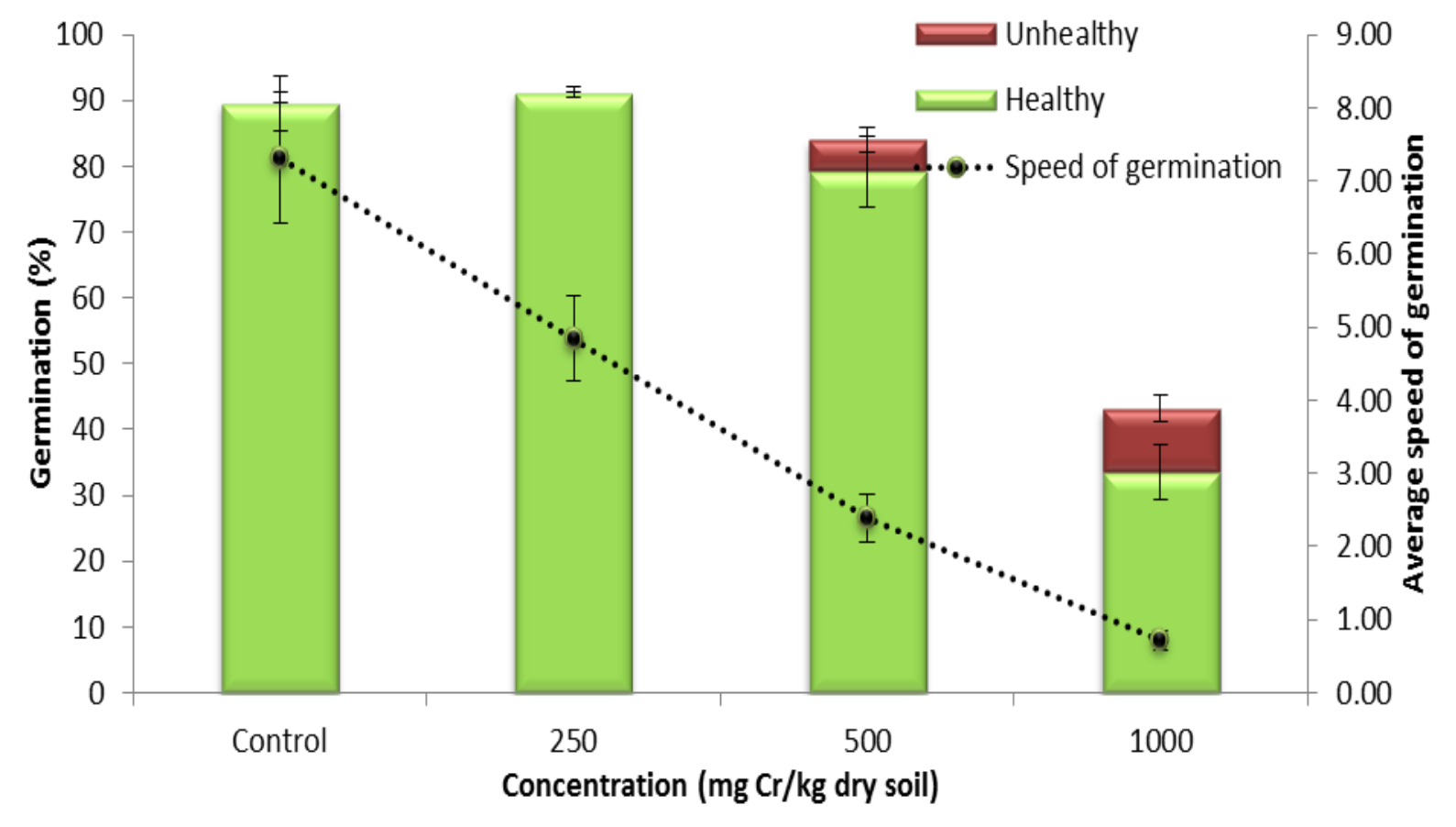

P. virgatum

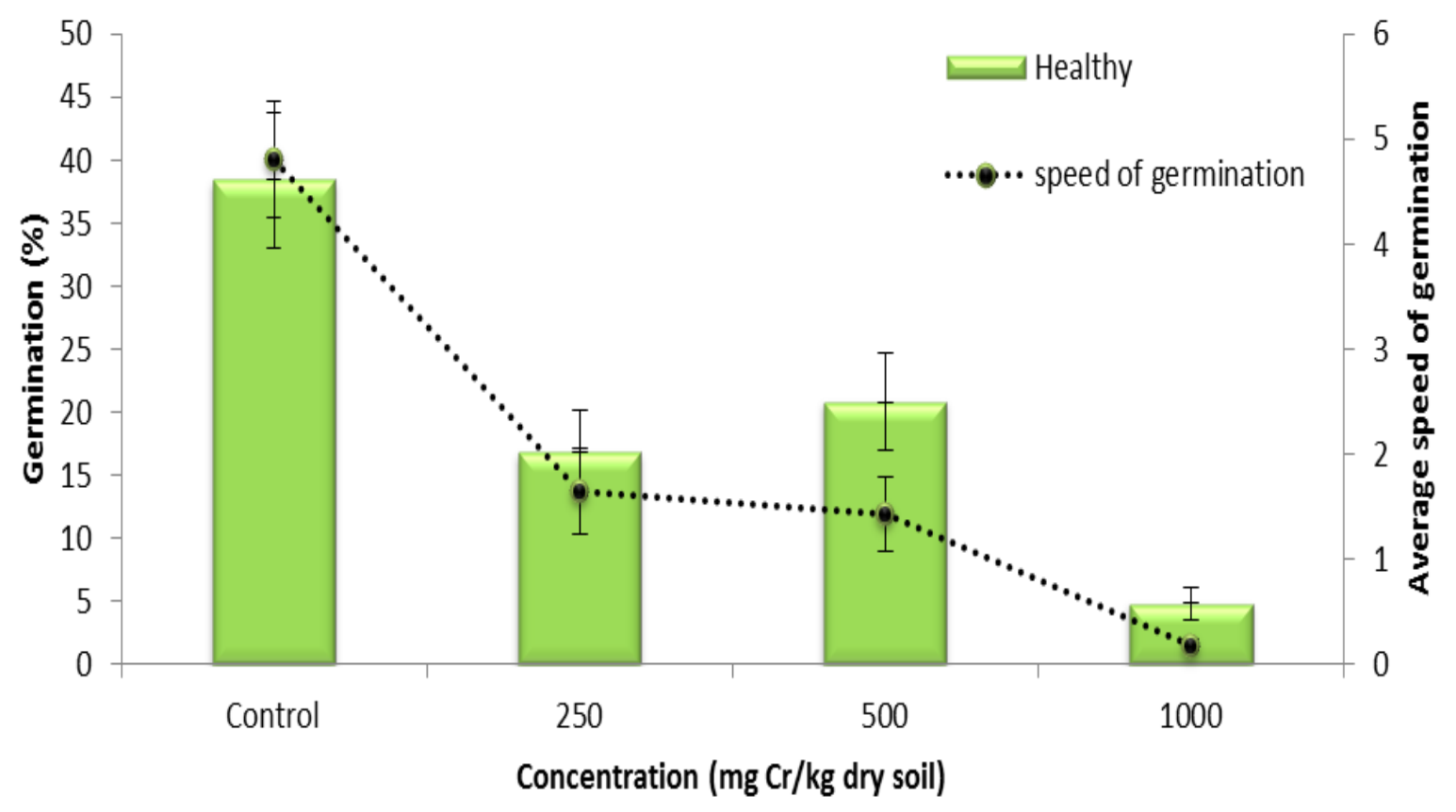


P. palustris

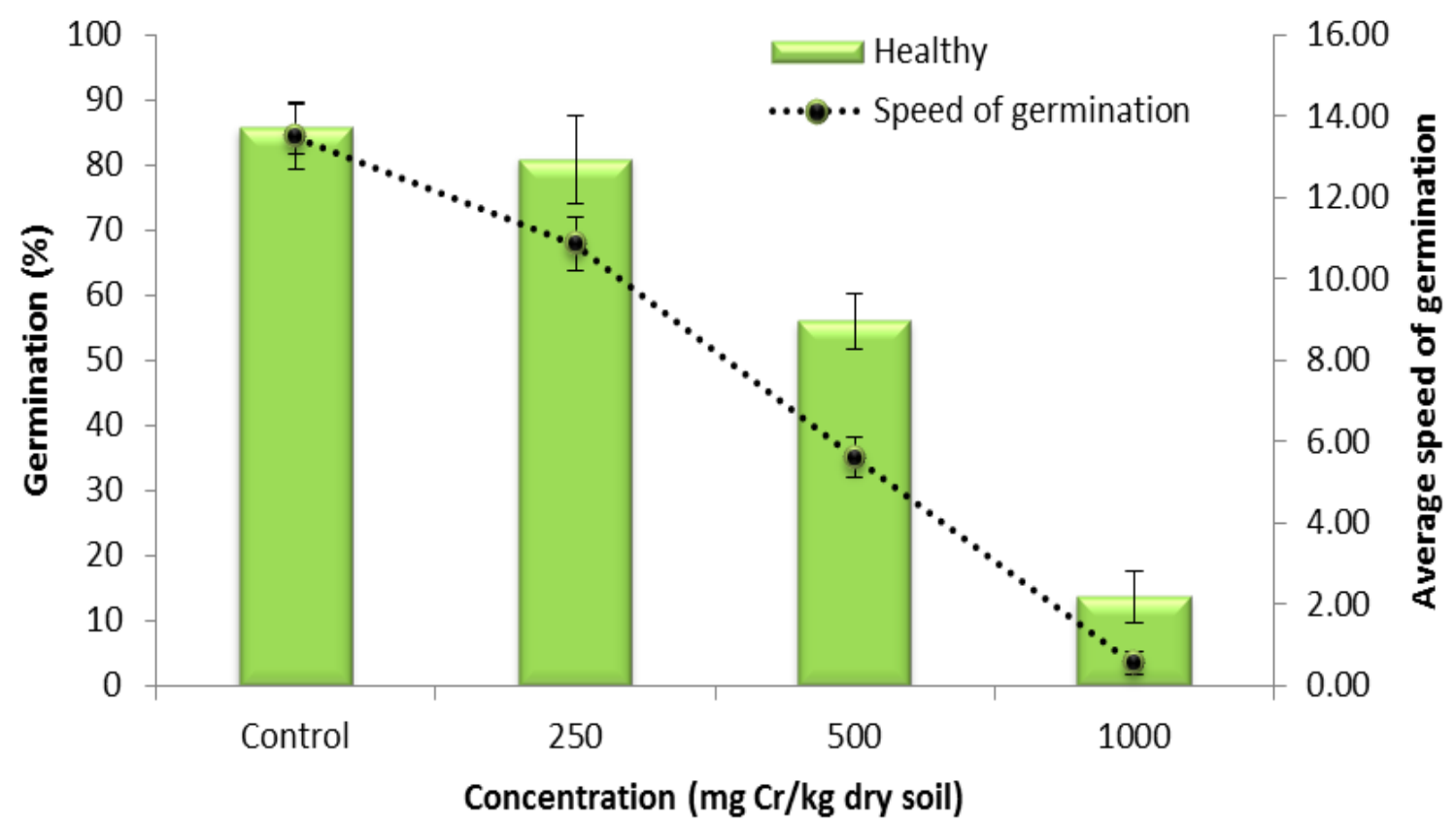

A. americanus

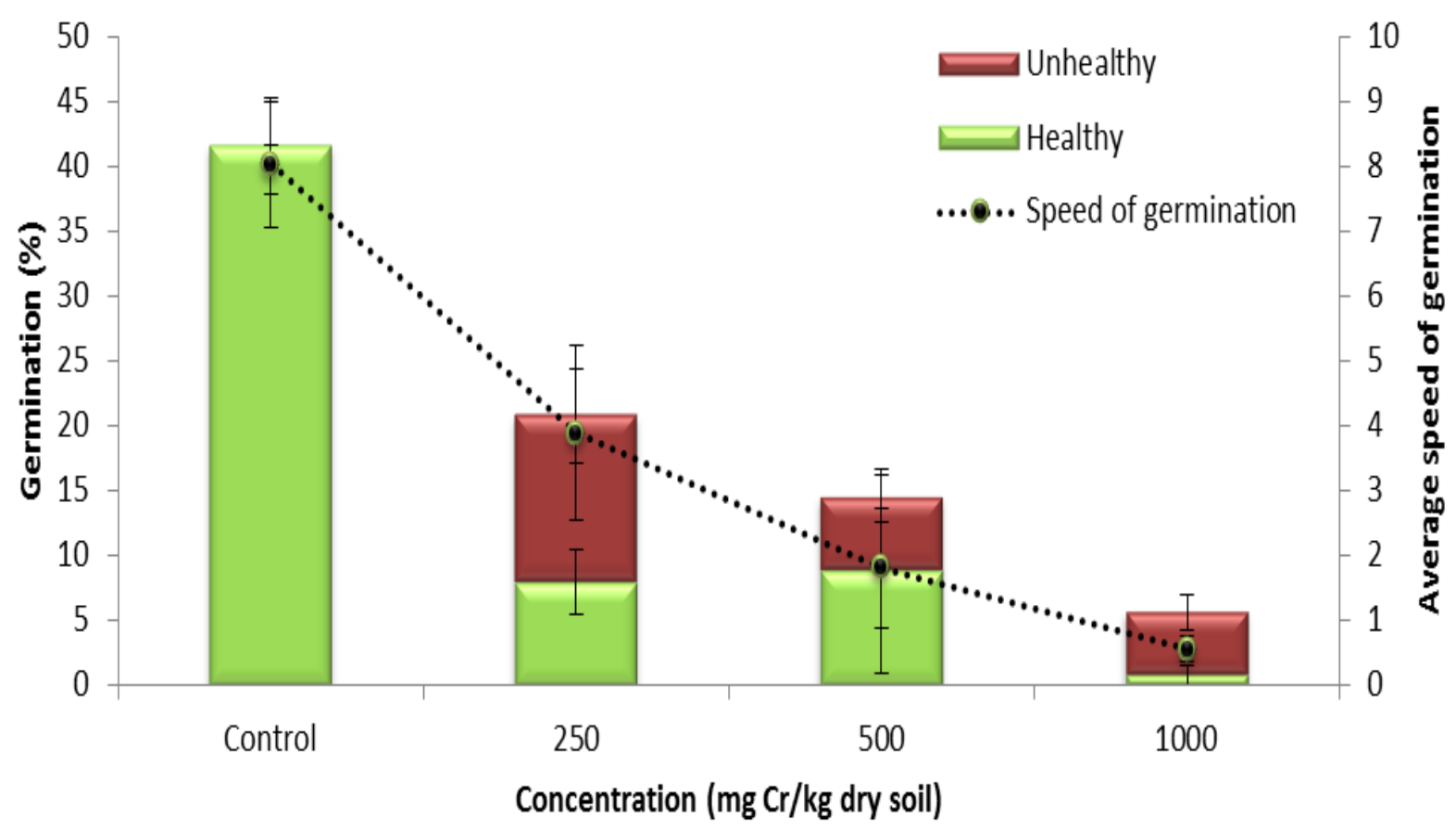


P. tremuloides

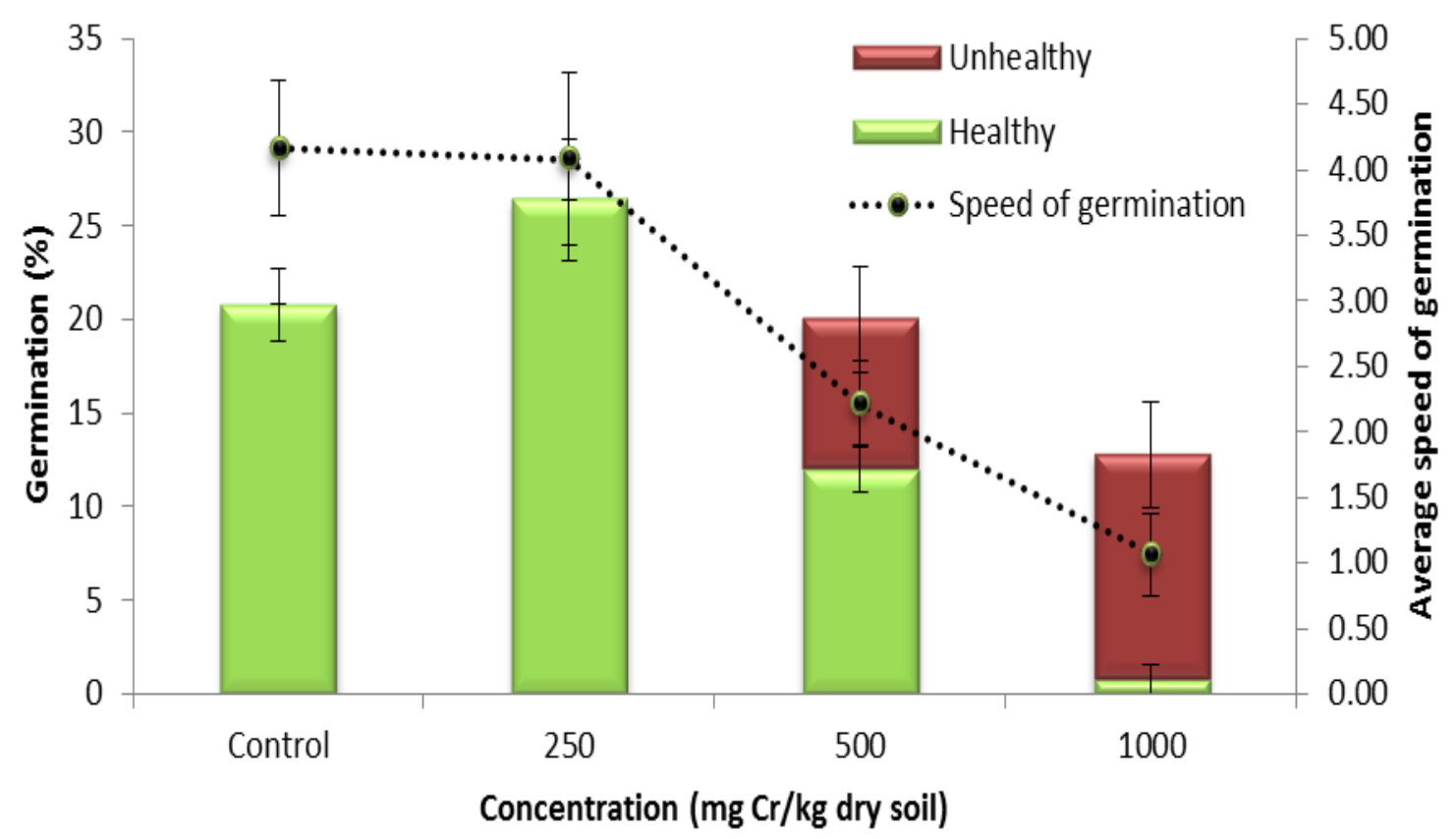

G. procumbens (Non-stratified)

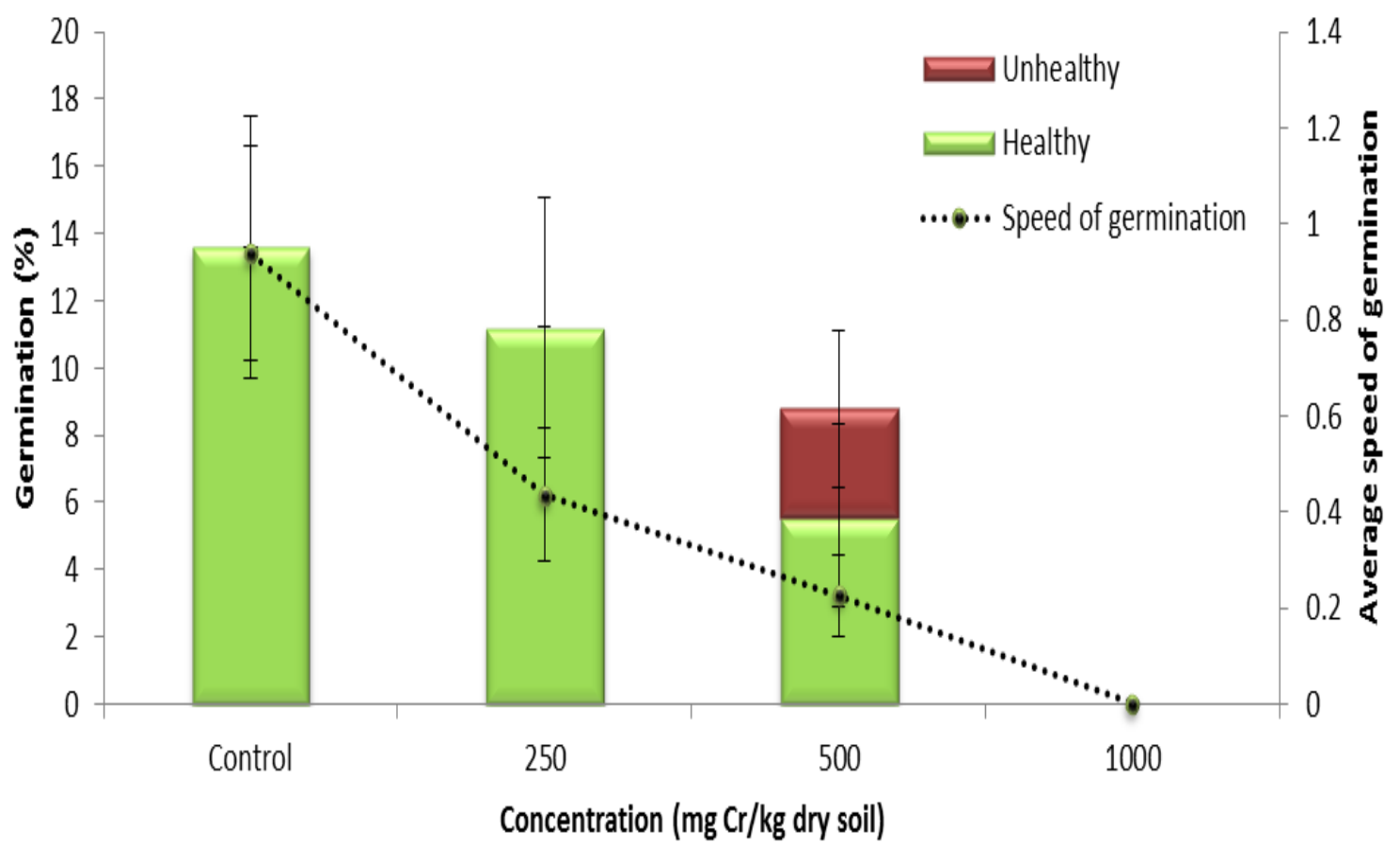


G. procumbens (Stratified)

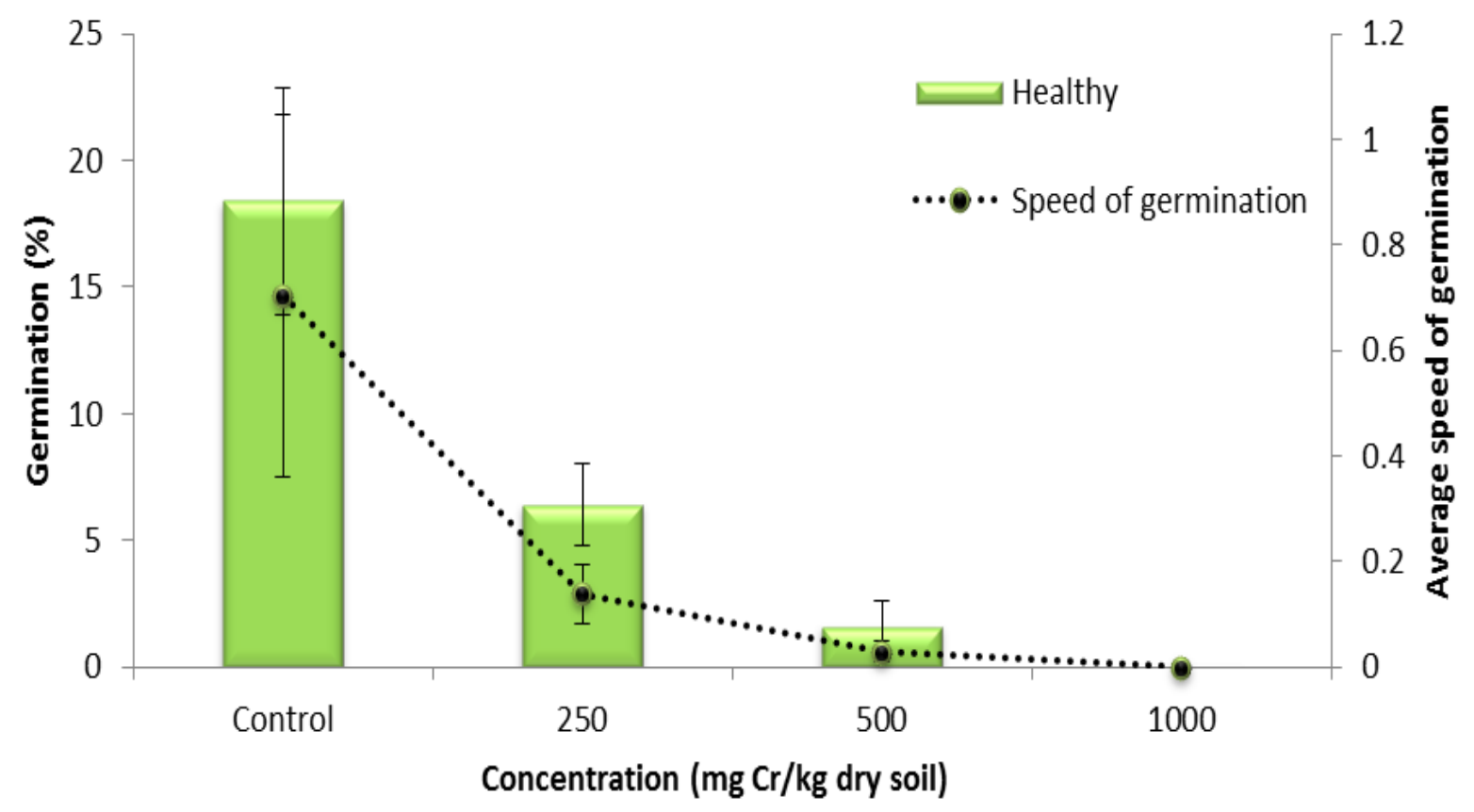

C. intybus

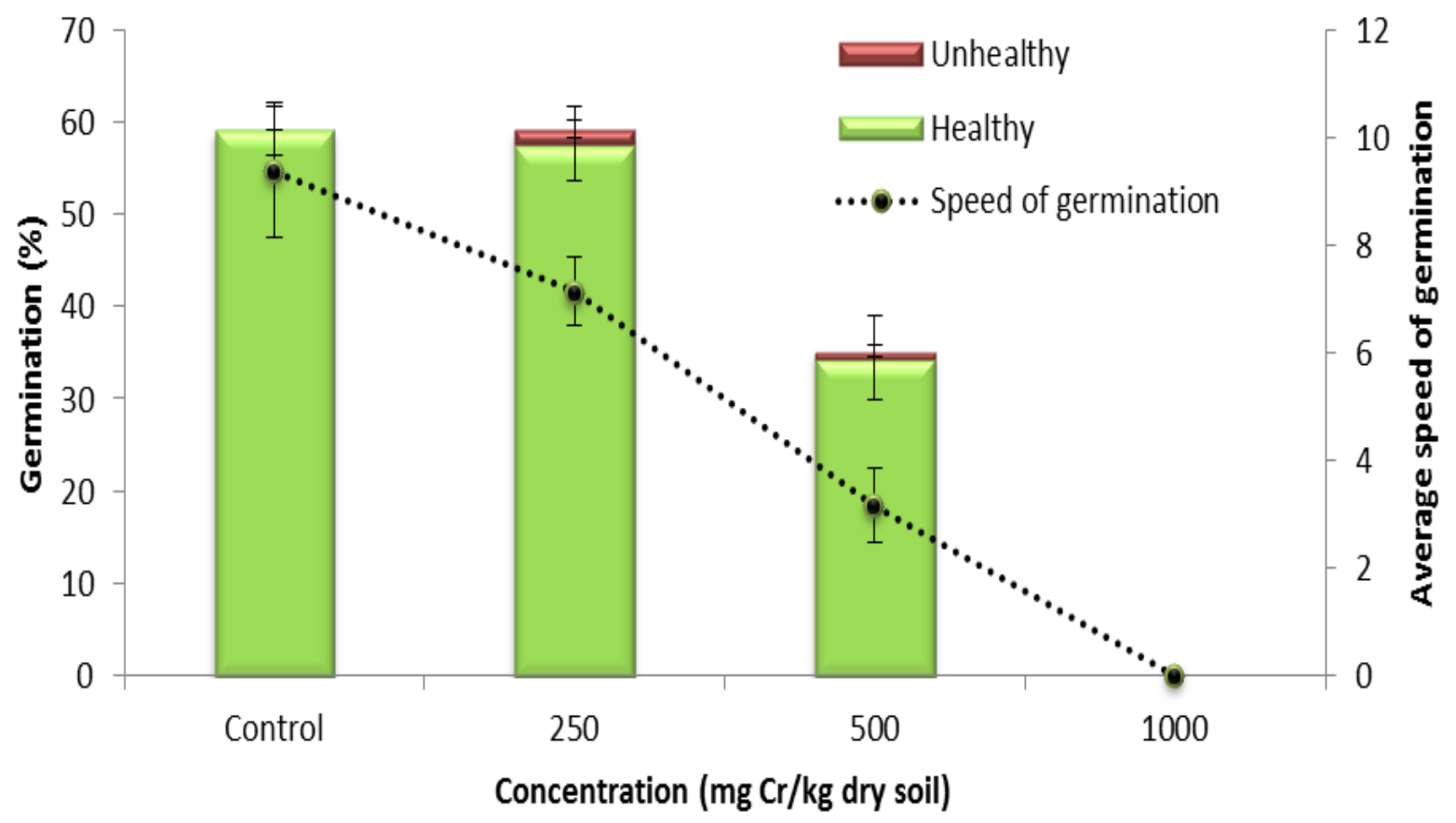




\section{T. officinale}

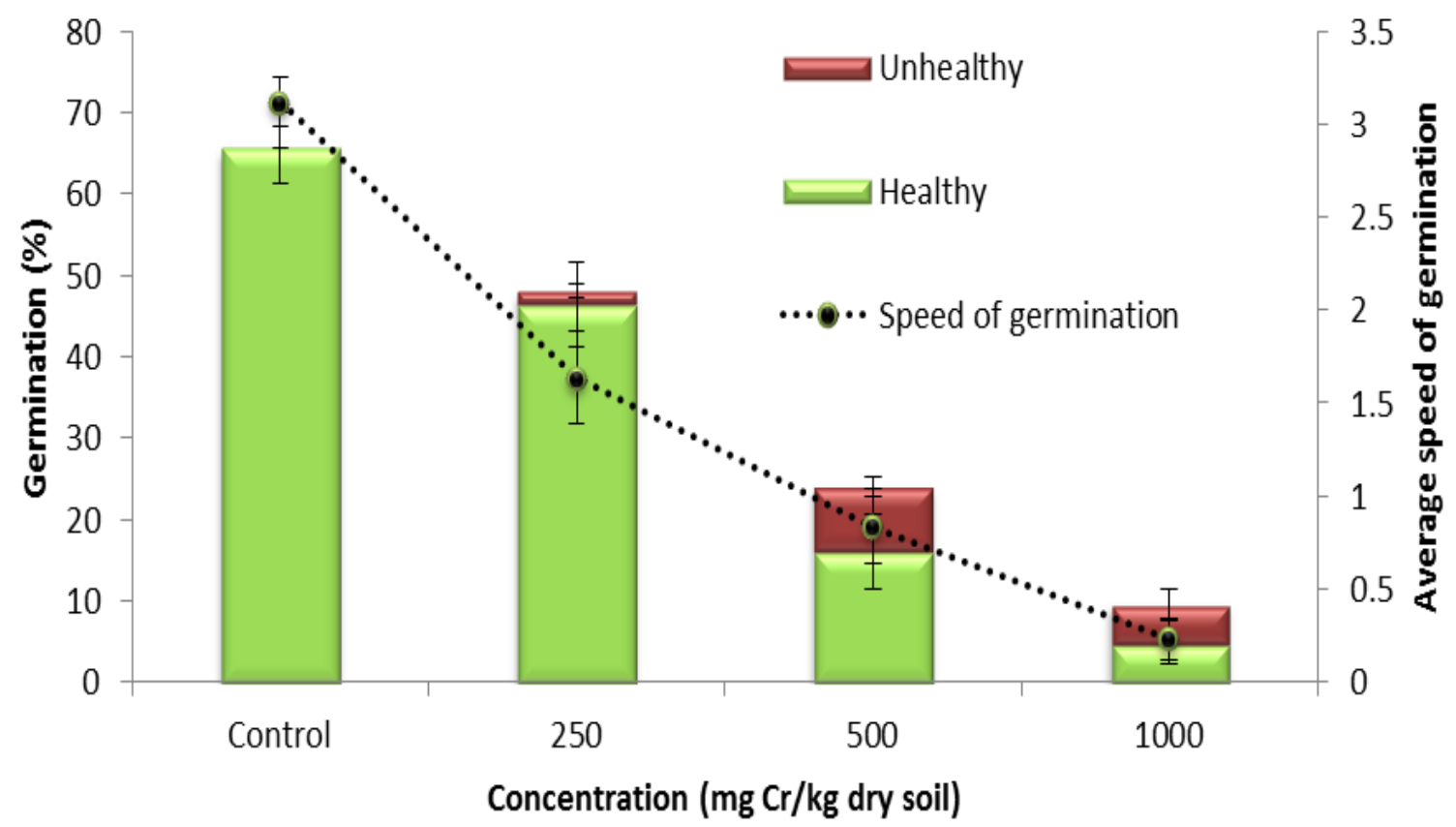

S. canadensis (Non-stratified)

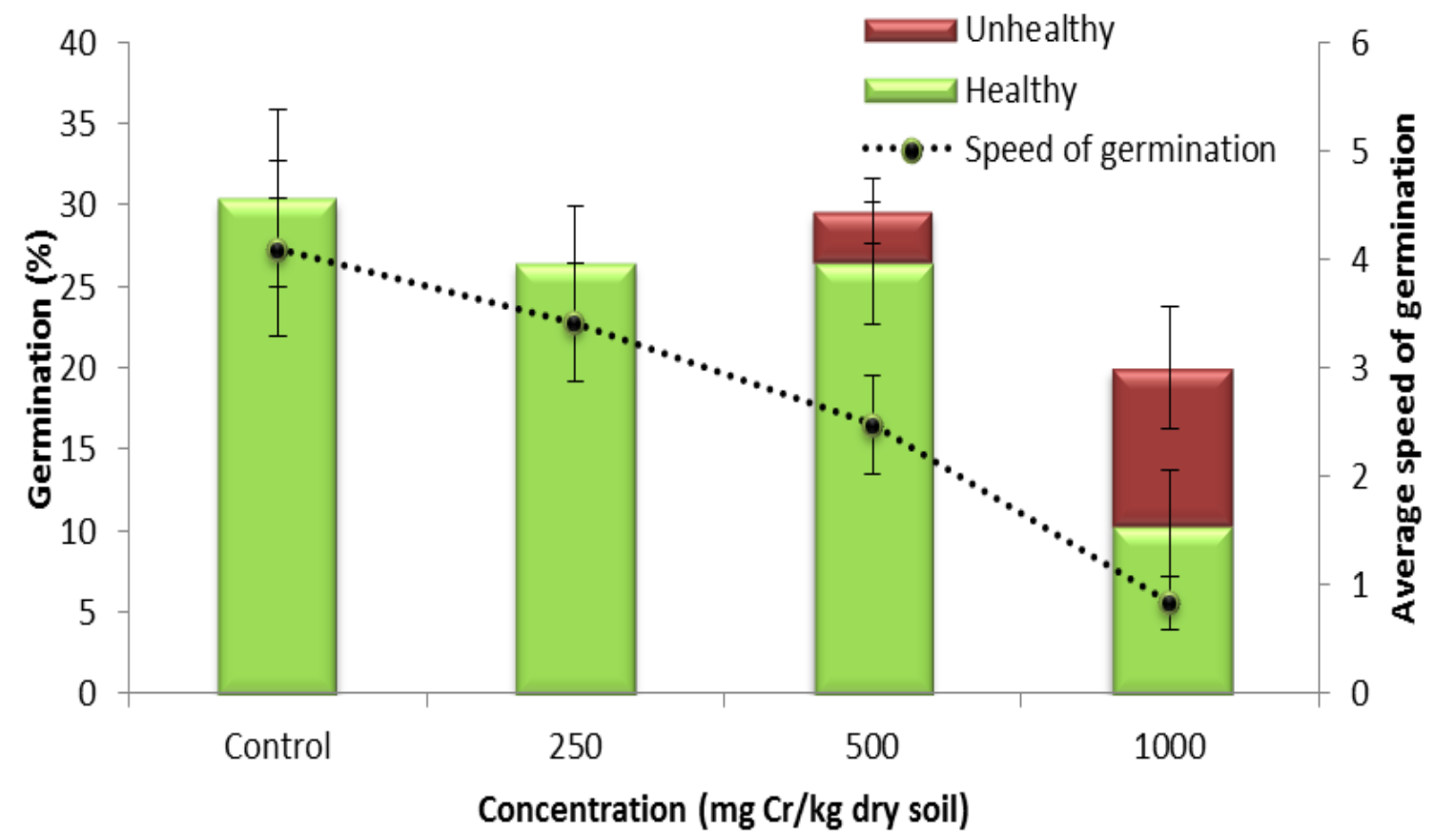


S. canadensis (Stratified)

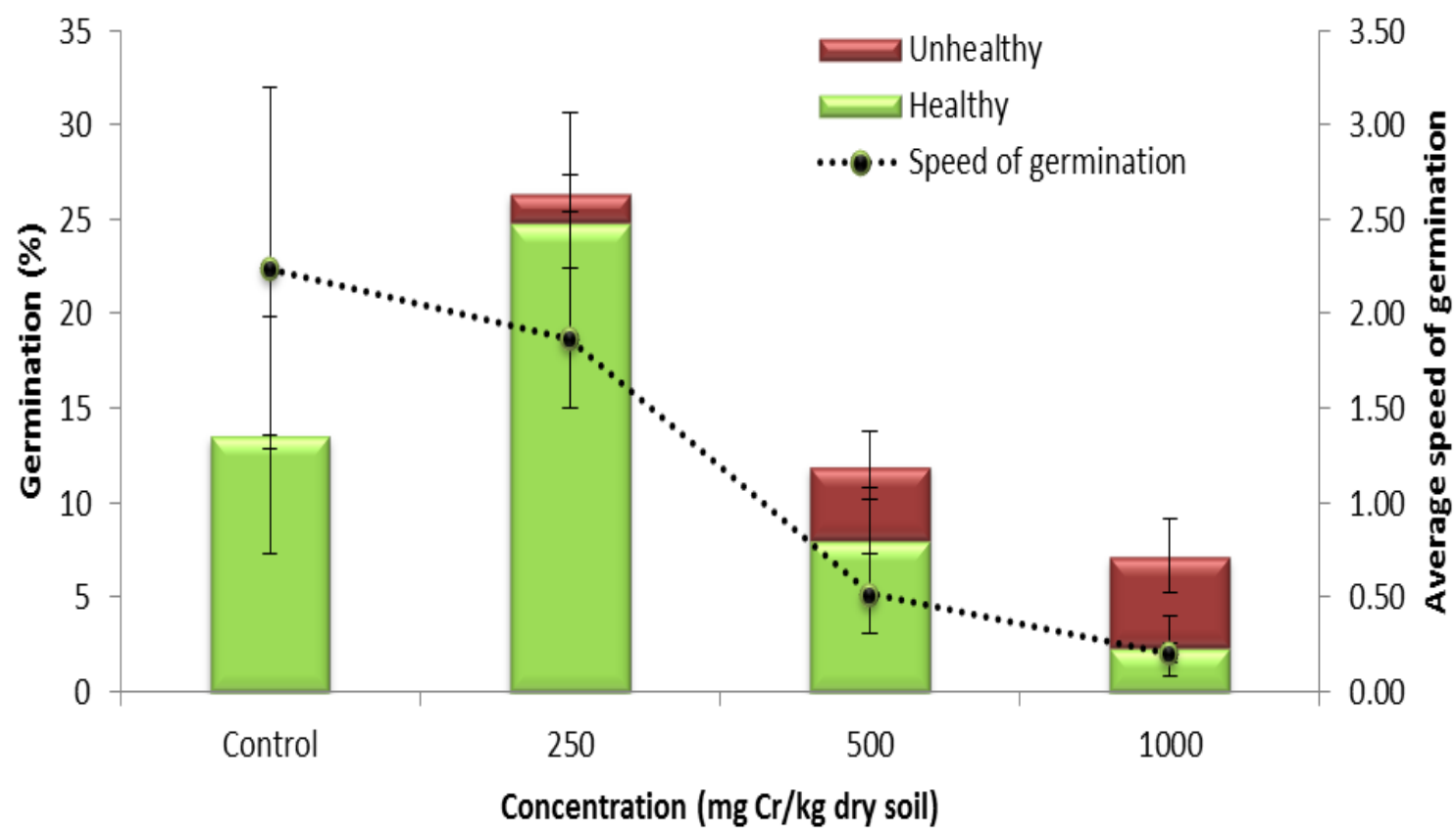

E. maculatum (Non-stratified)

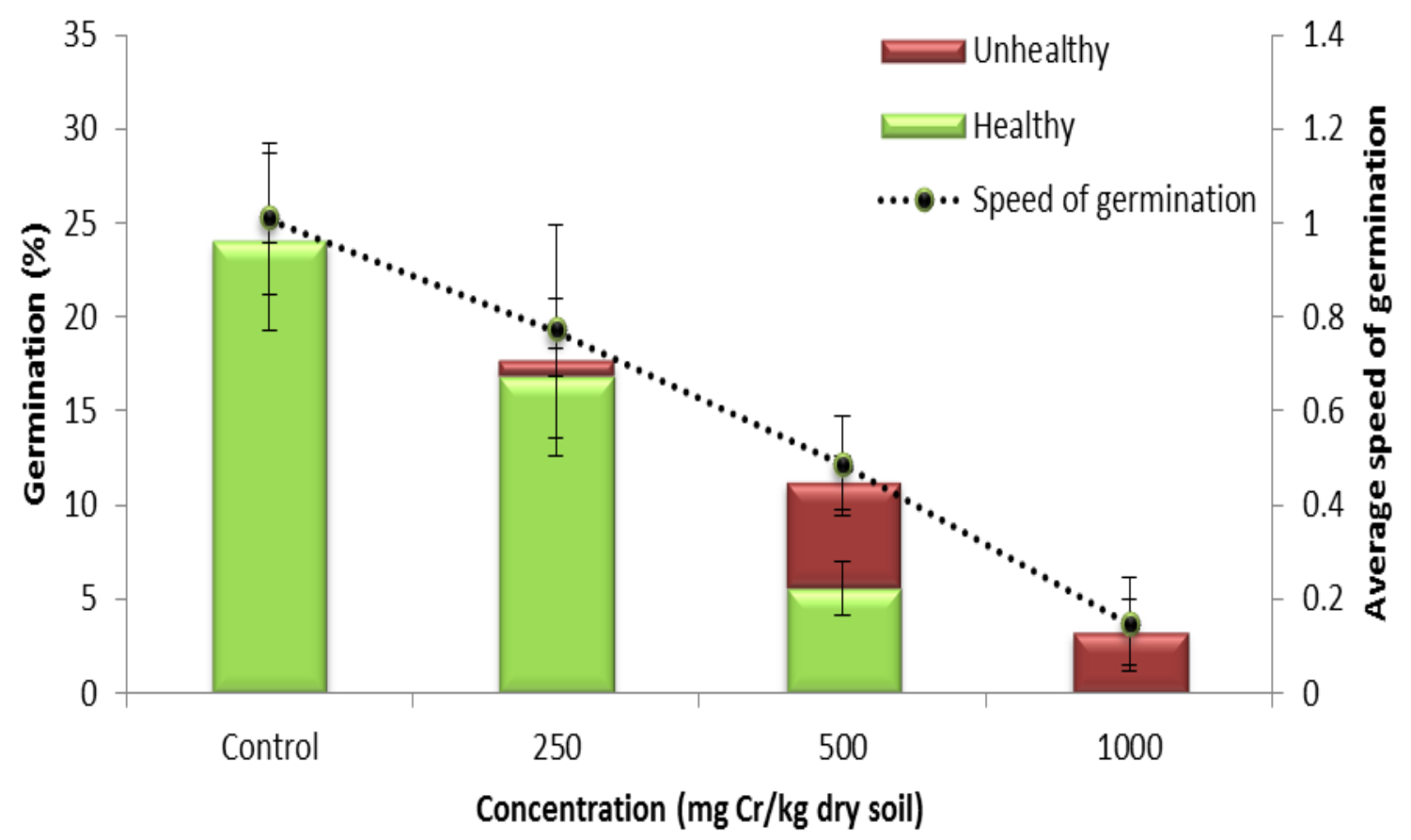


E. maculatum (Stratified)

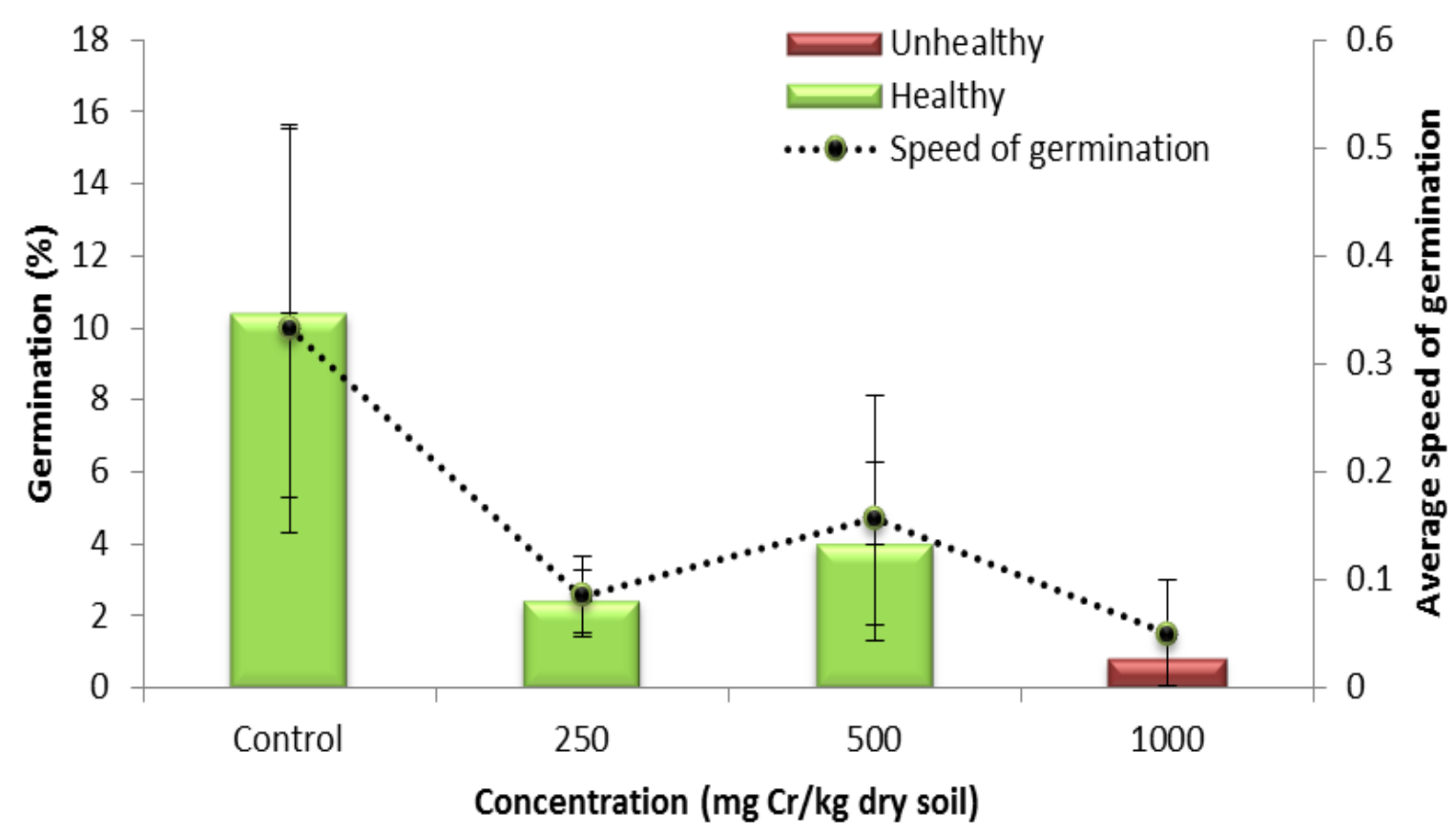

D. canadense




$N$. cataria

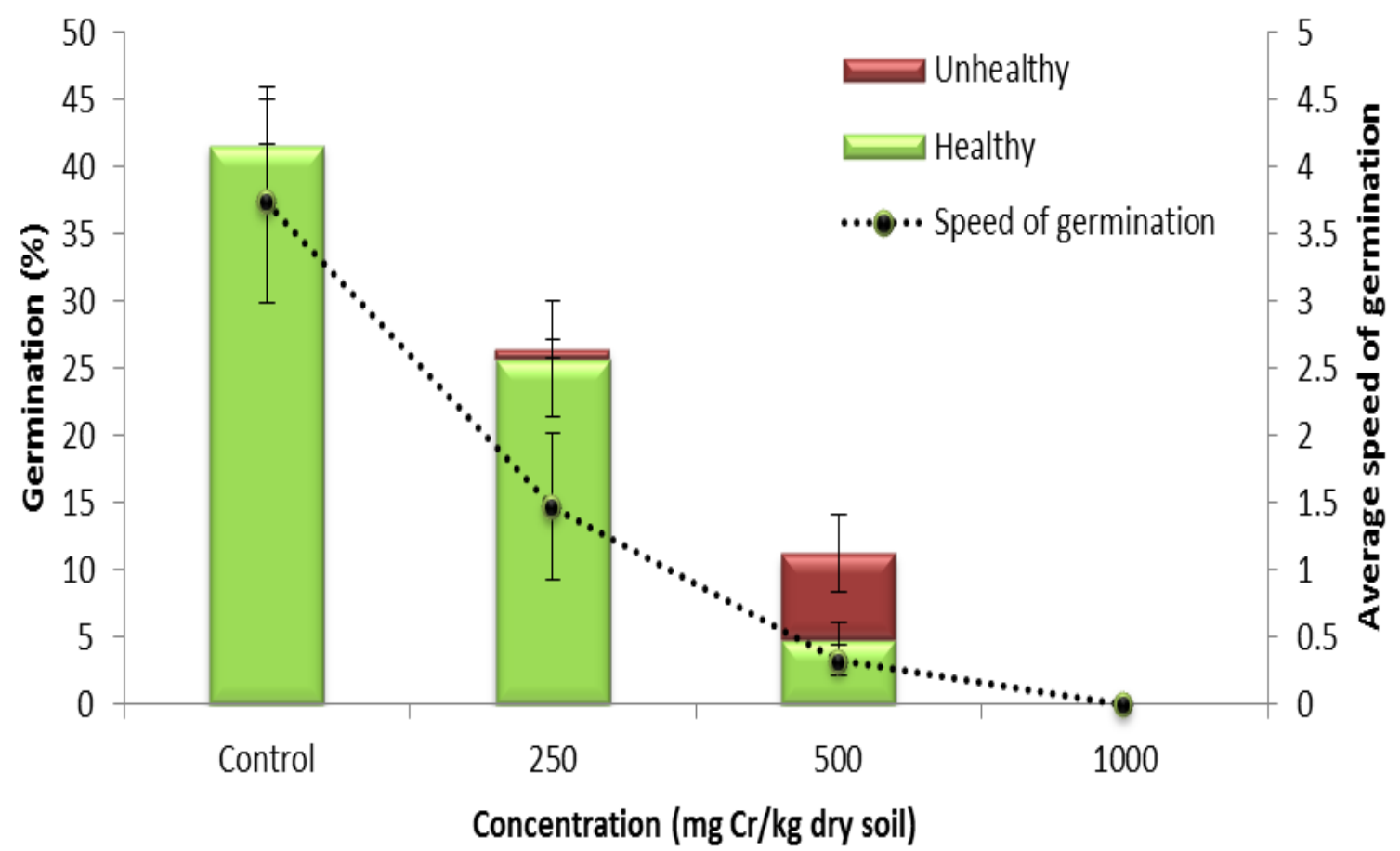

M. officinalis

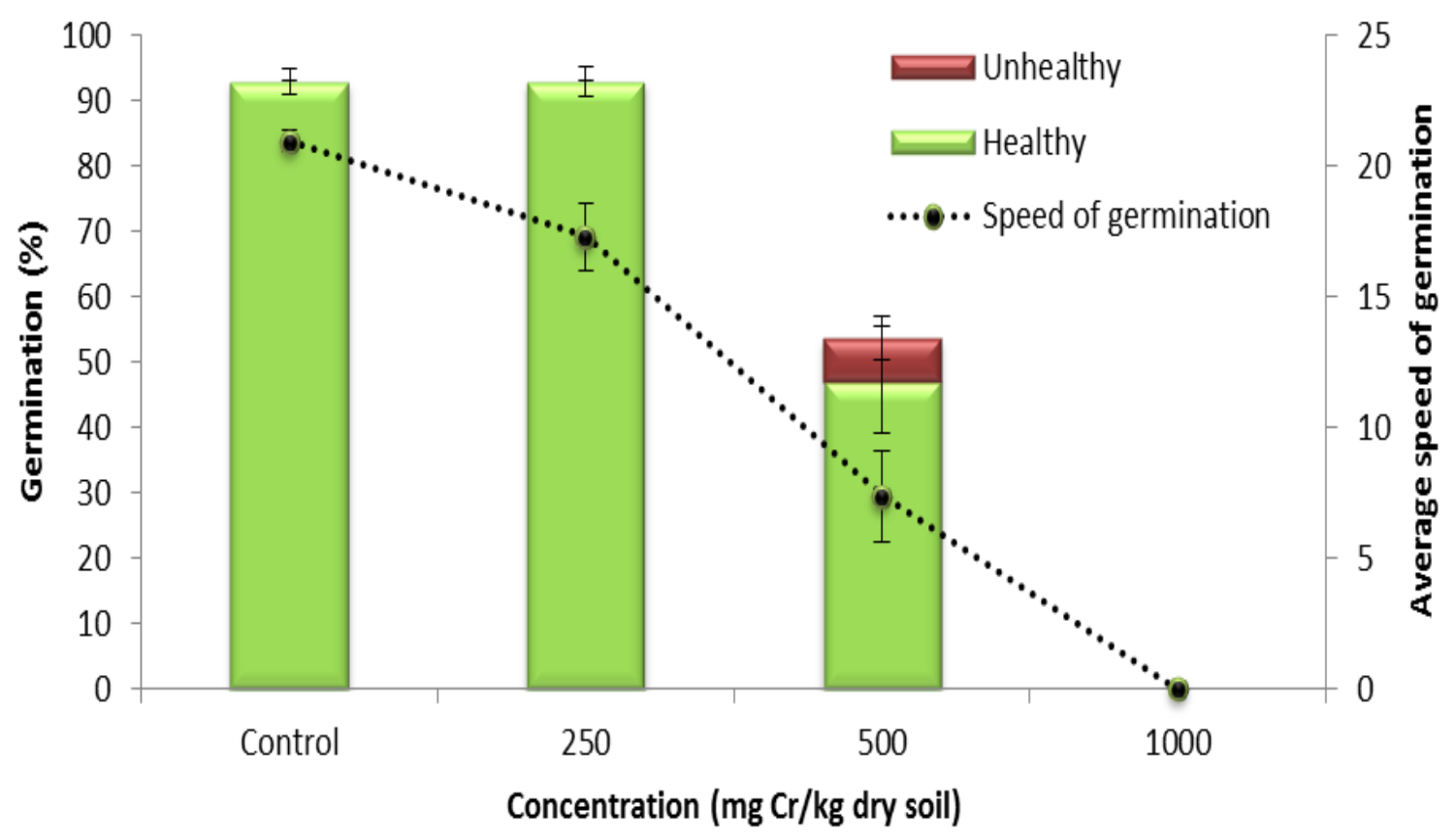


M. arvensis

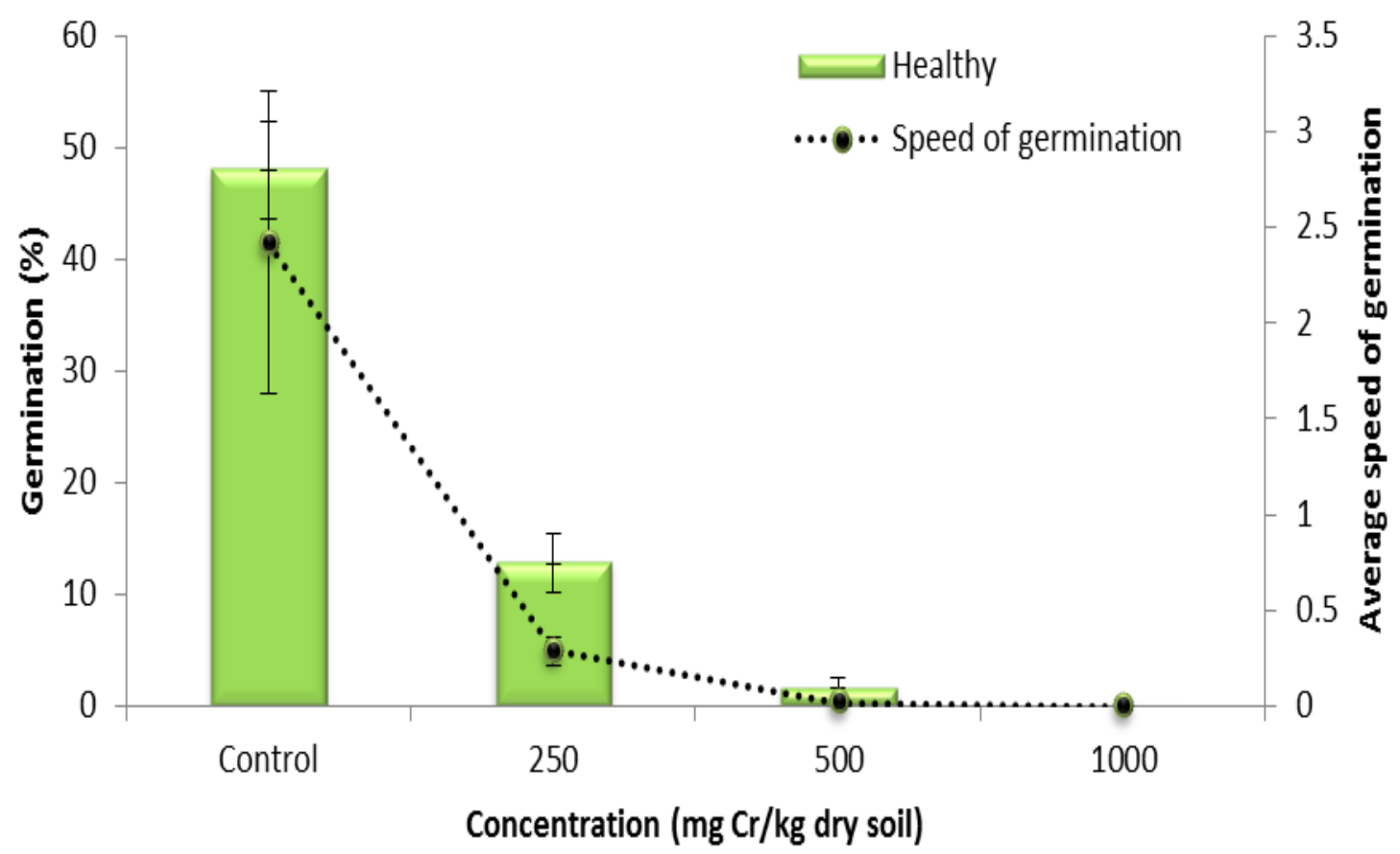

S. officinalis

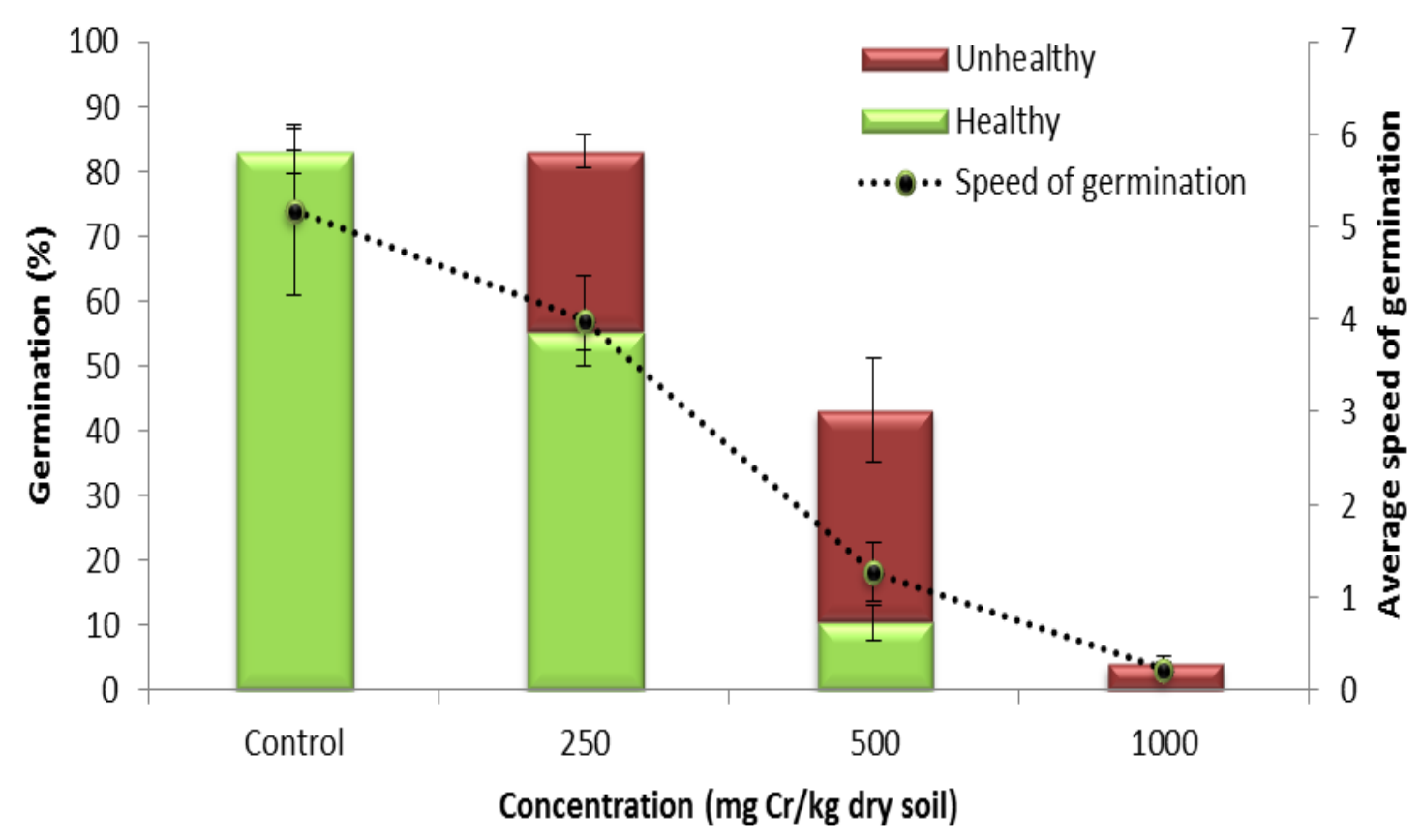


R. acetosa

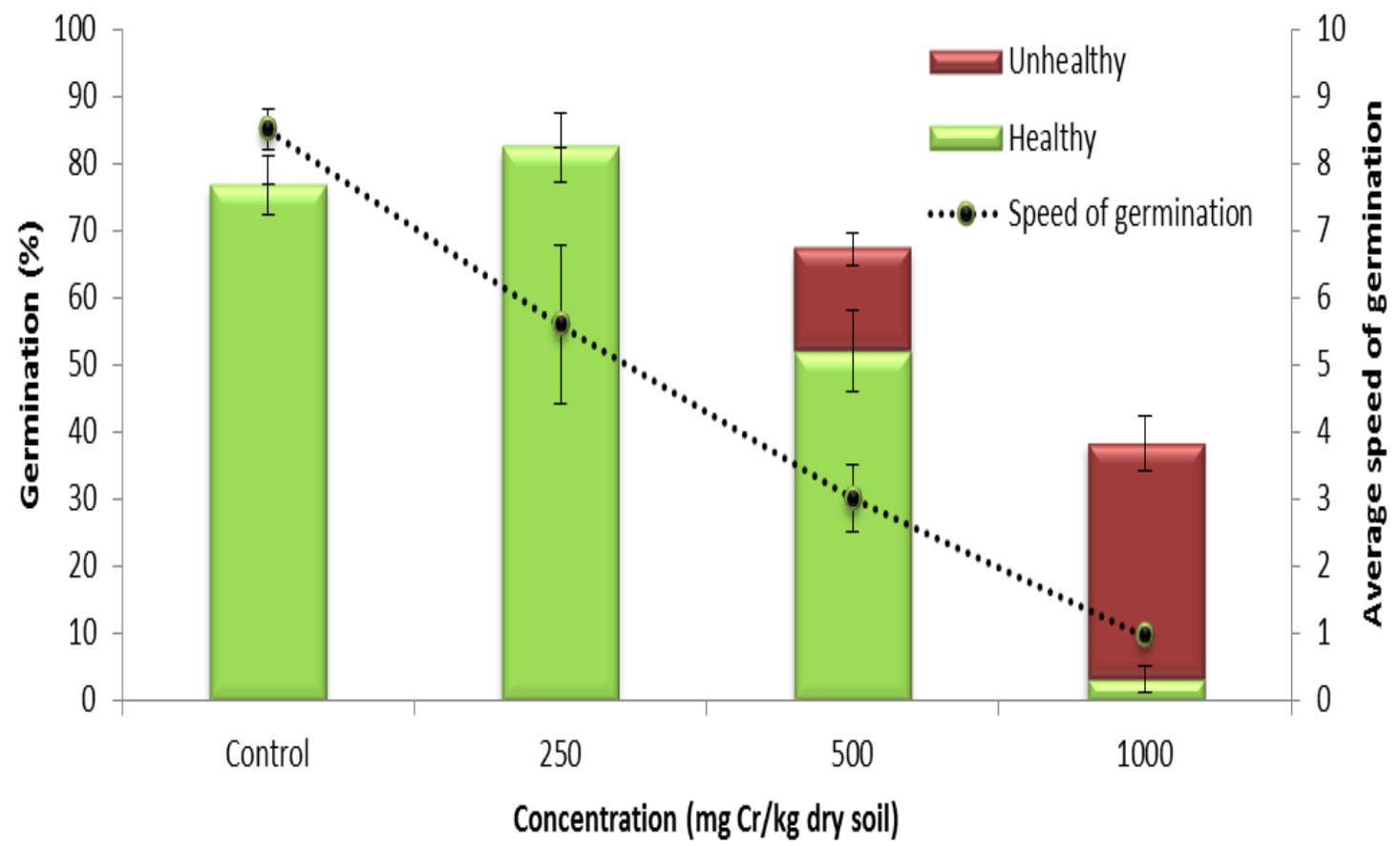

C. album

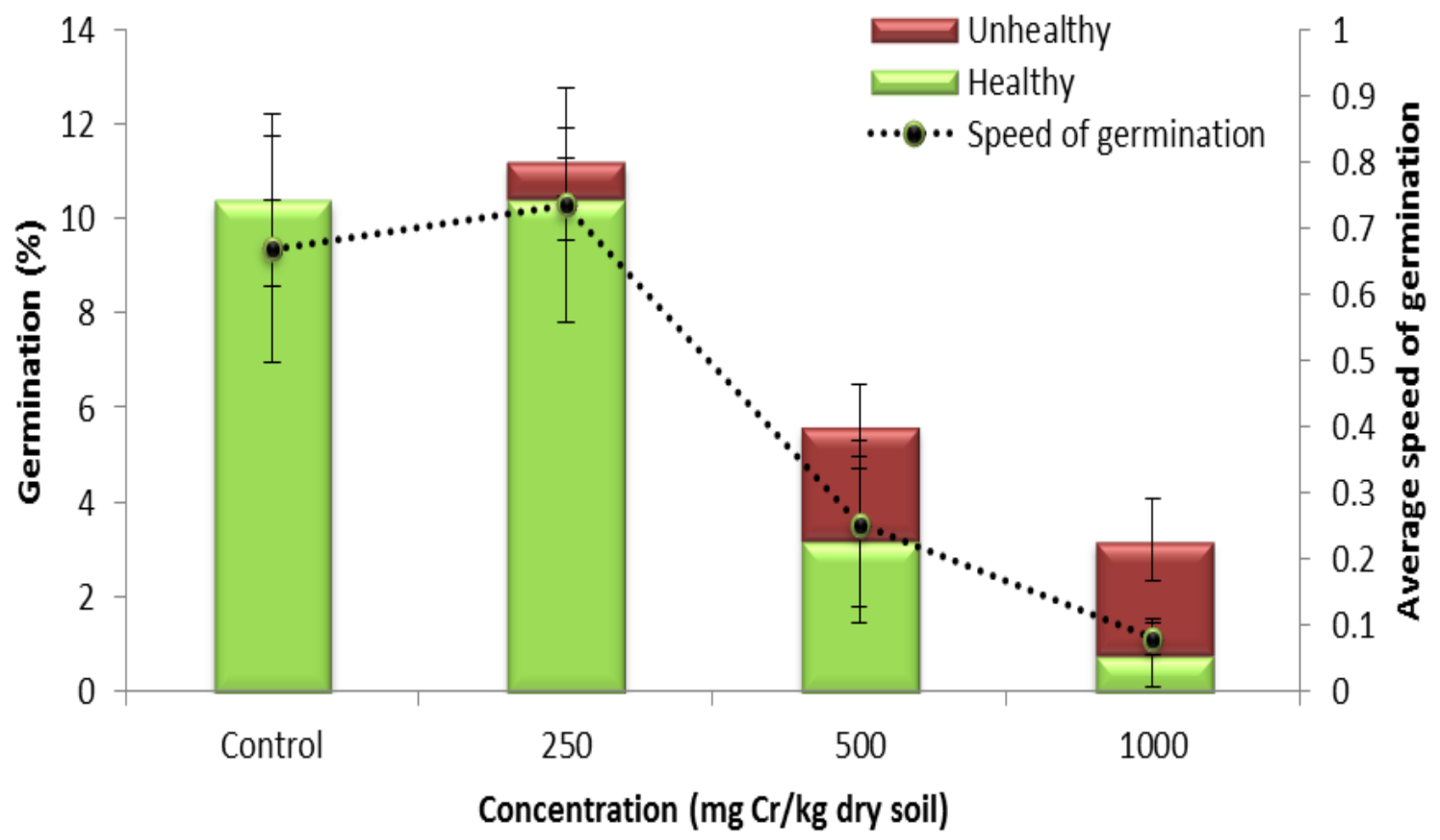


A. syriaca (Non-stratified)

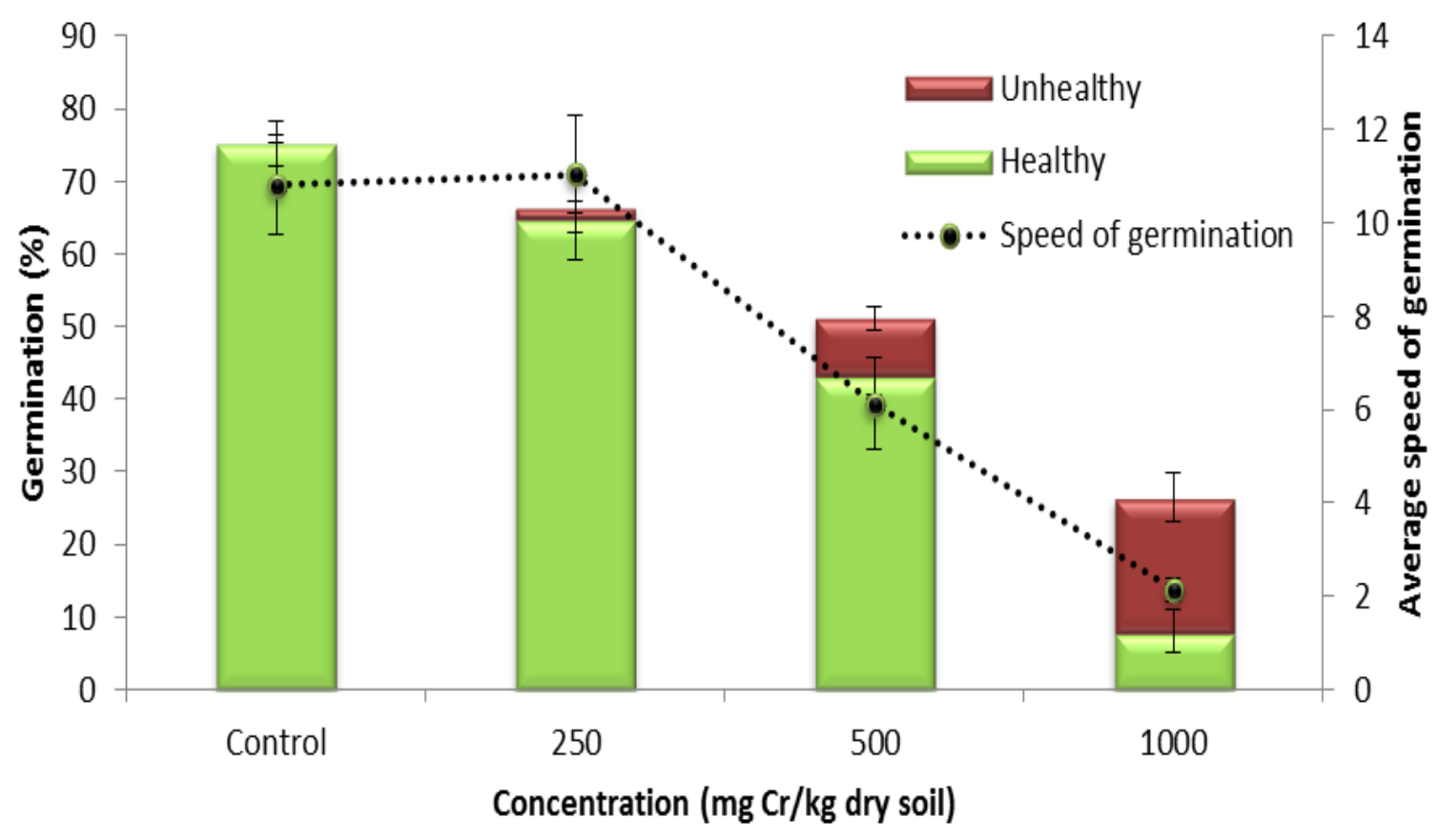

A. syriaca (Stratified)

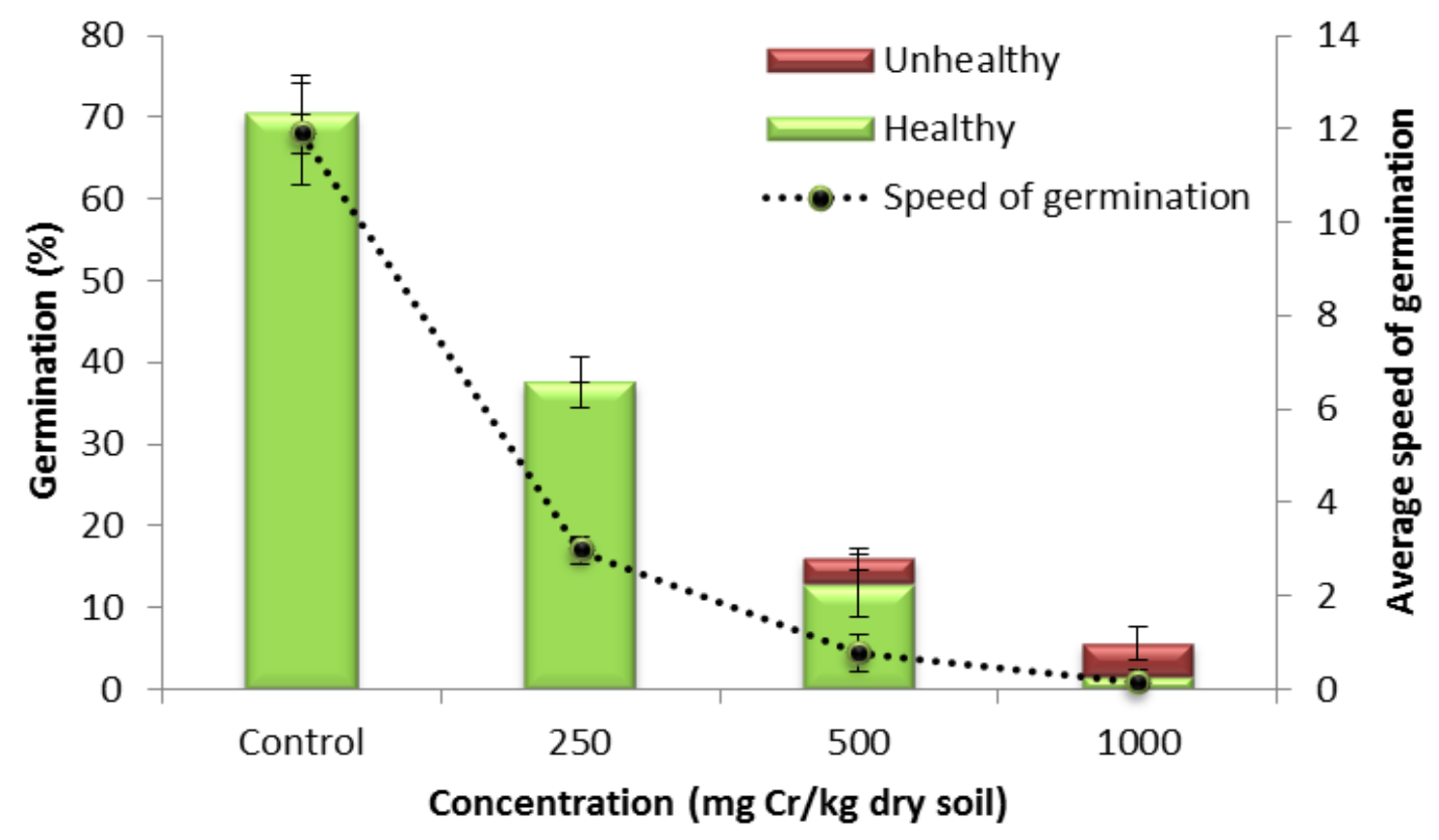


H. perforatum (Non-stratified)

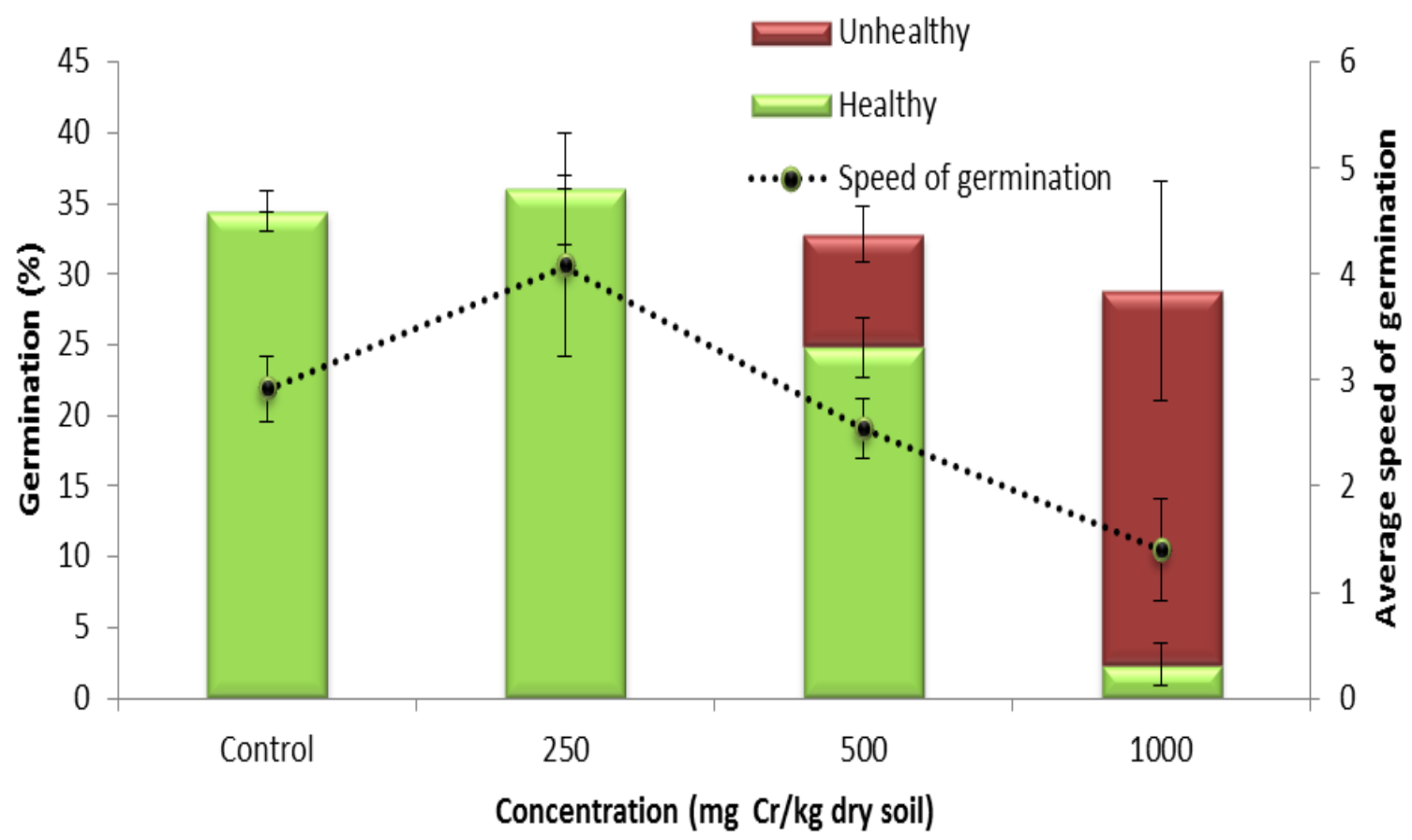

H. perforatum (Stratified)

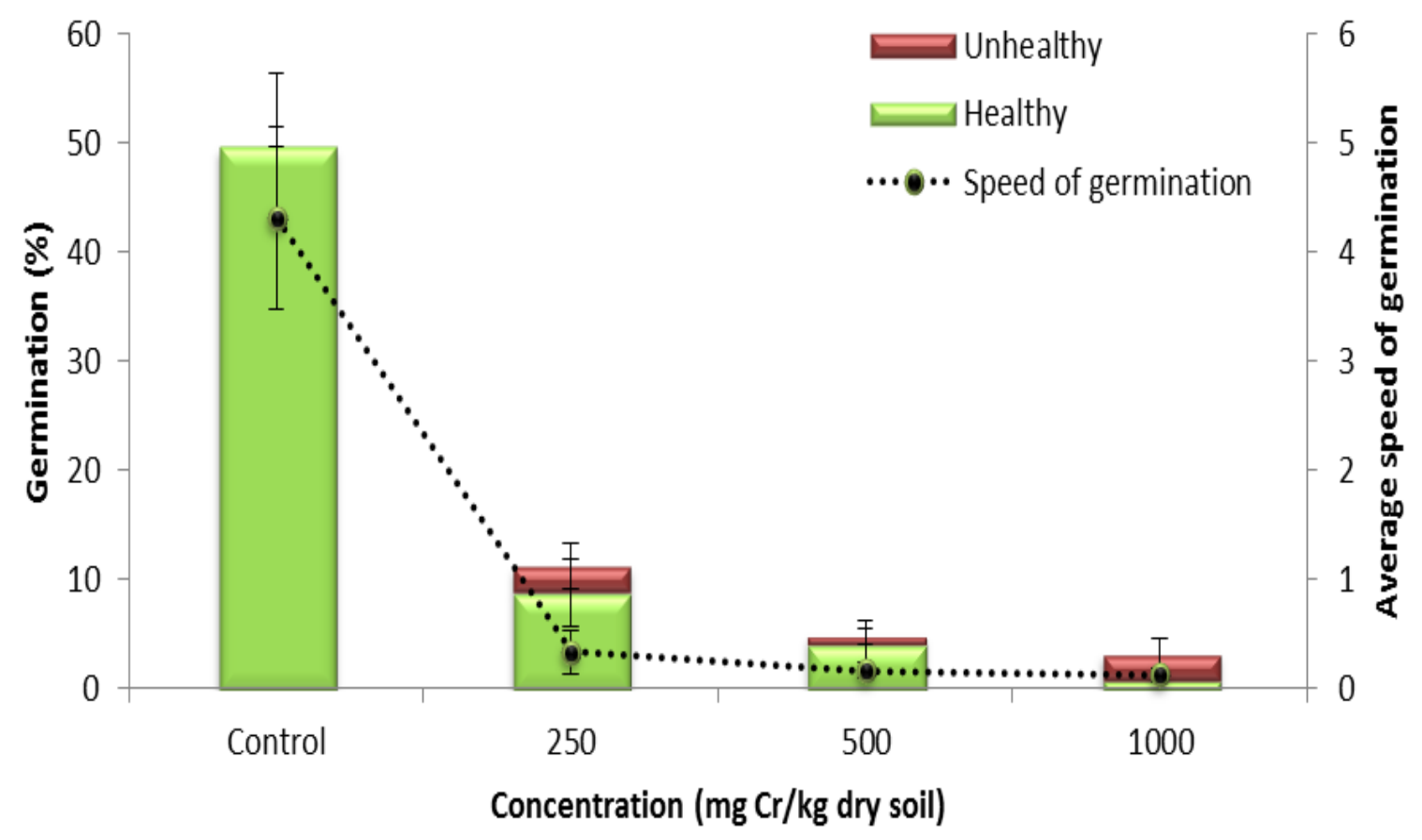


U. dioica

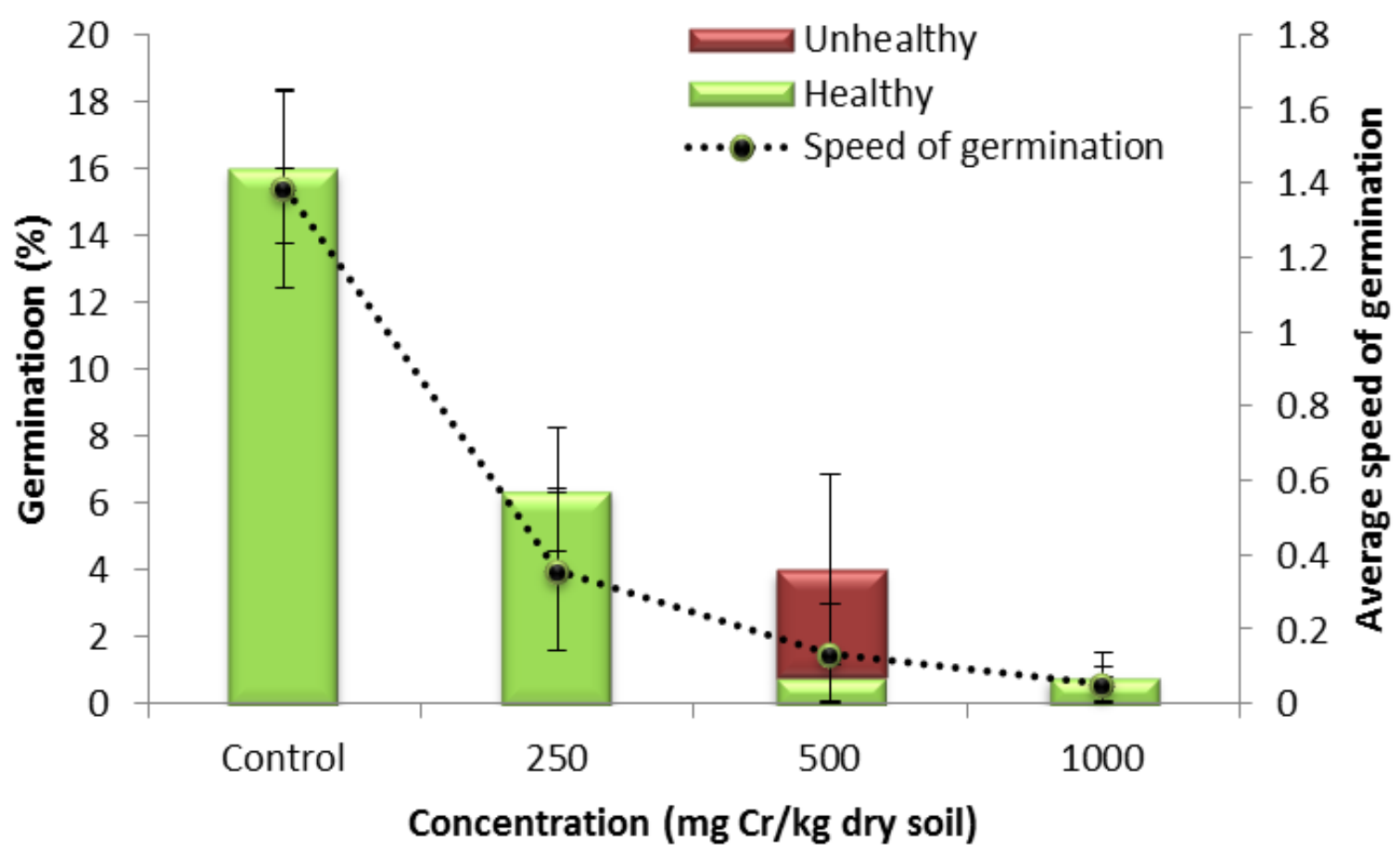

V. hastata (Non-stratified)

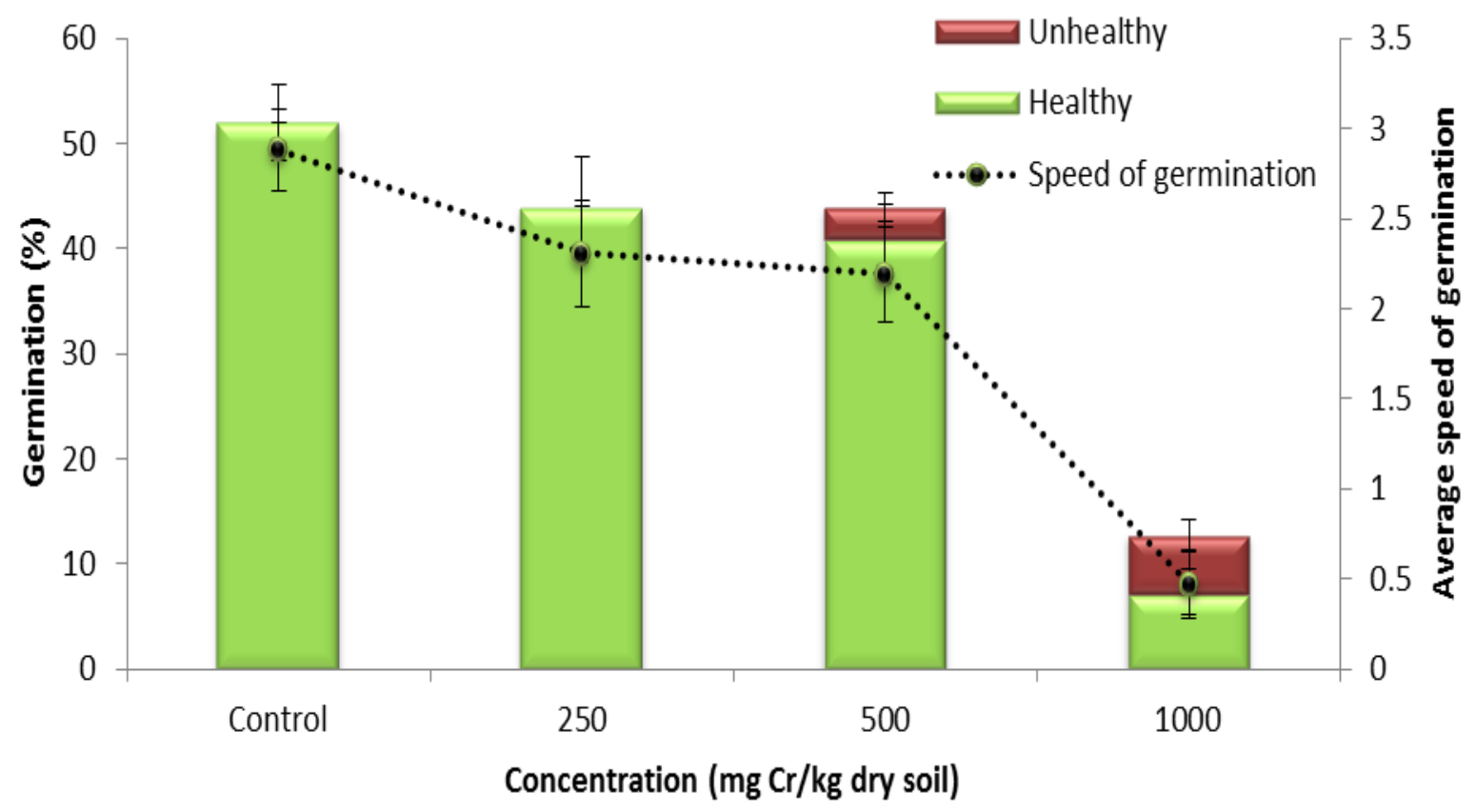


V. hastata (Stratified)

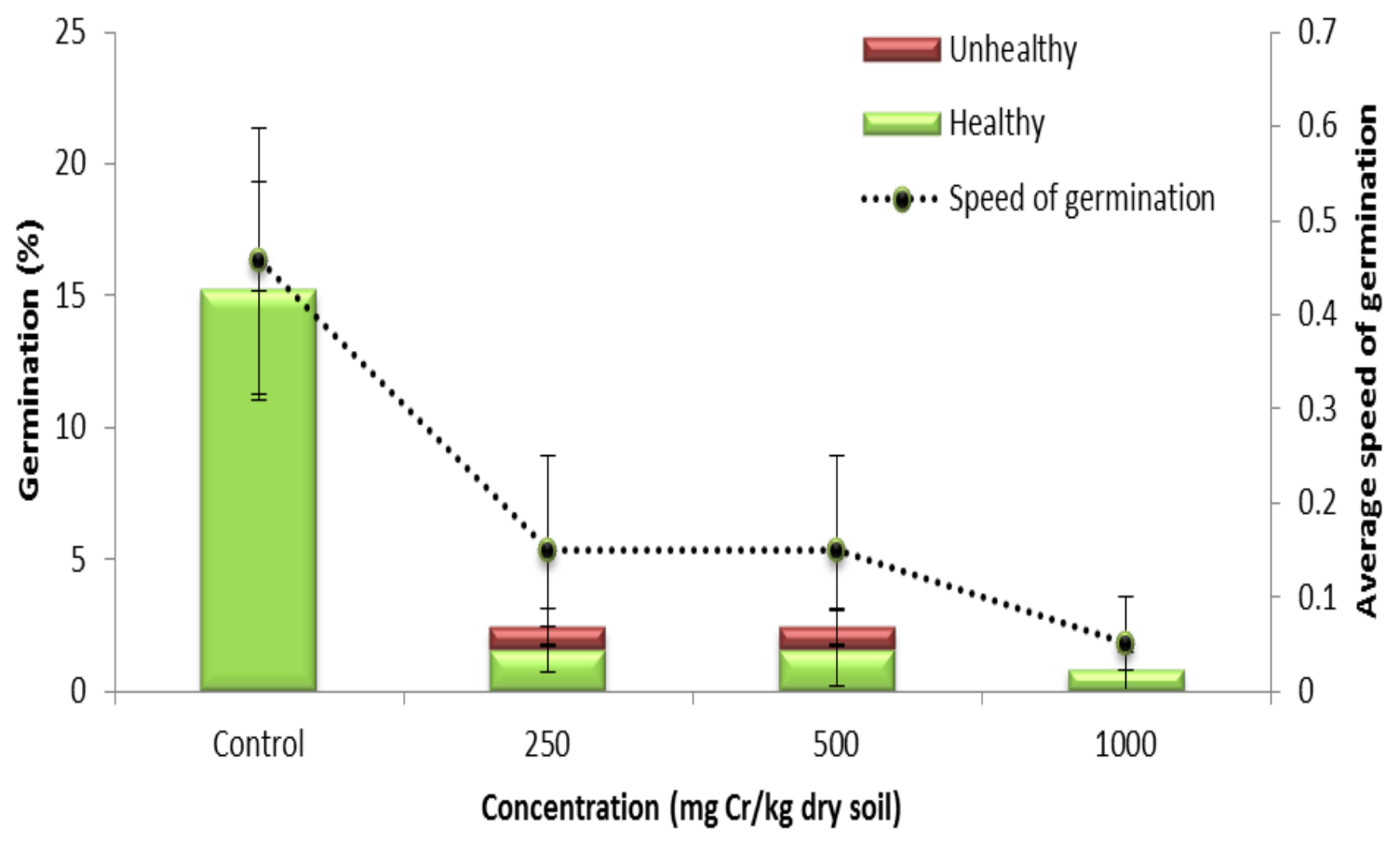

H. moscheutos

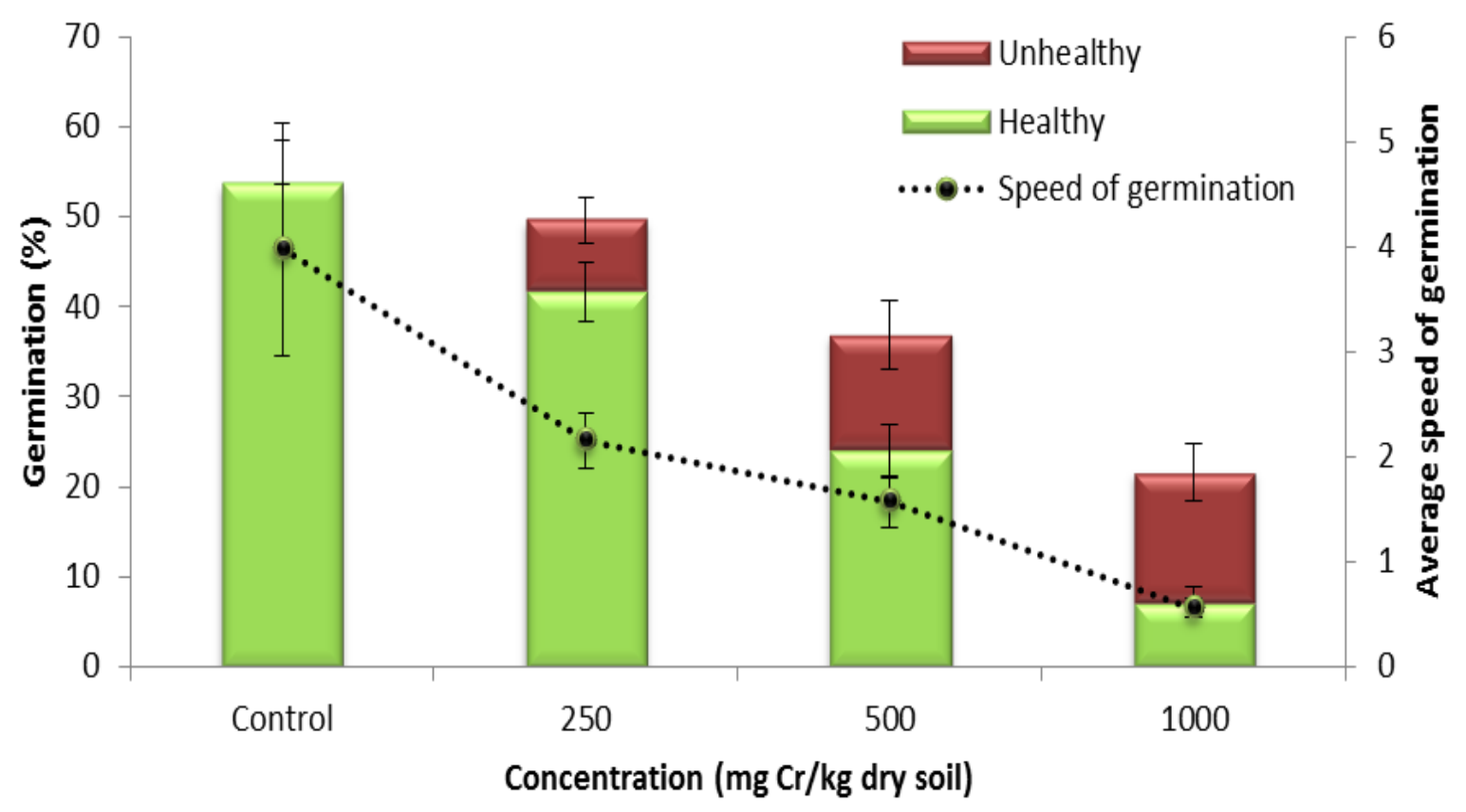


A. rosea

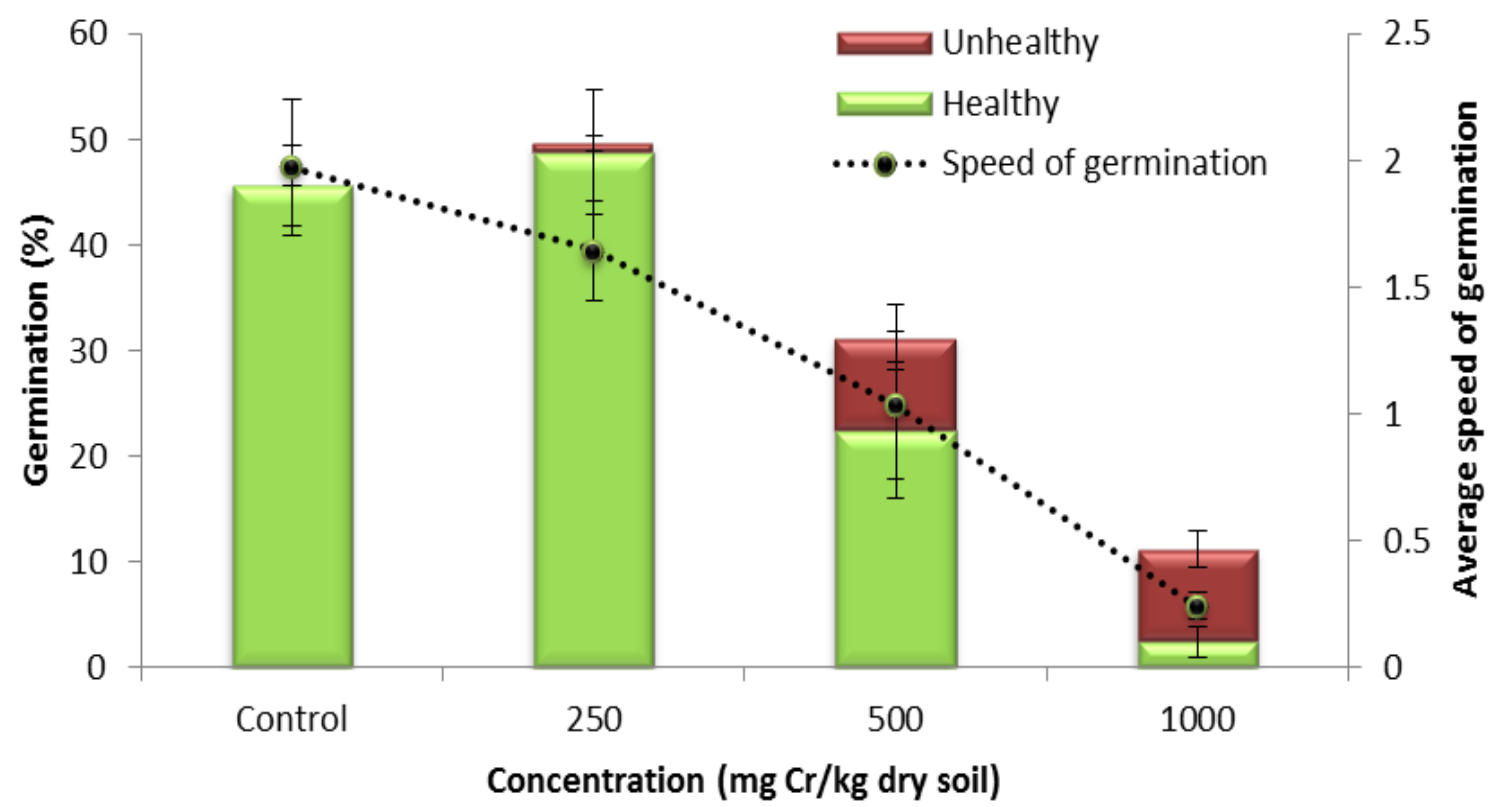

I. purpurea

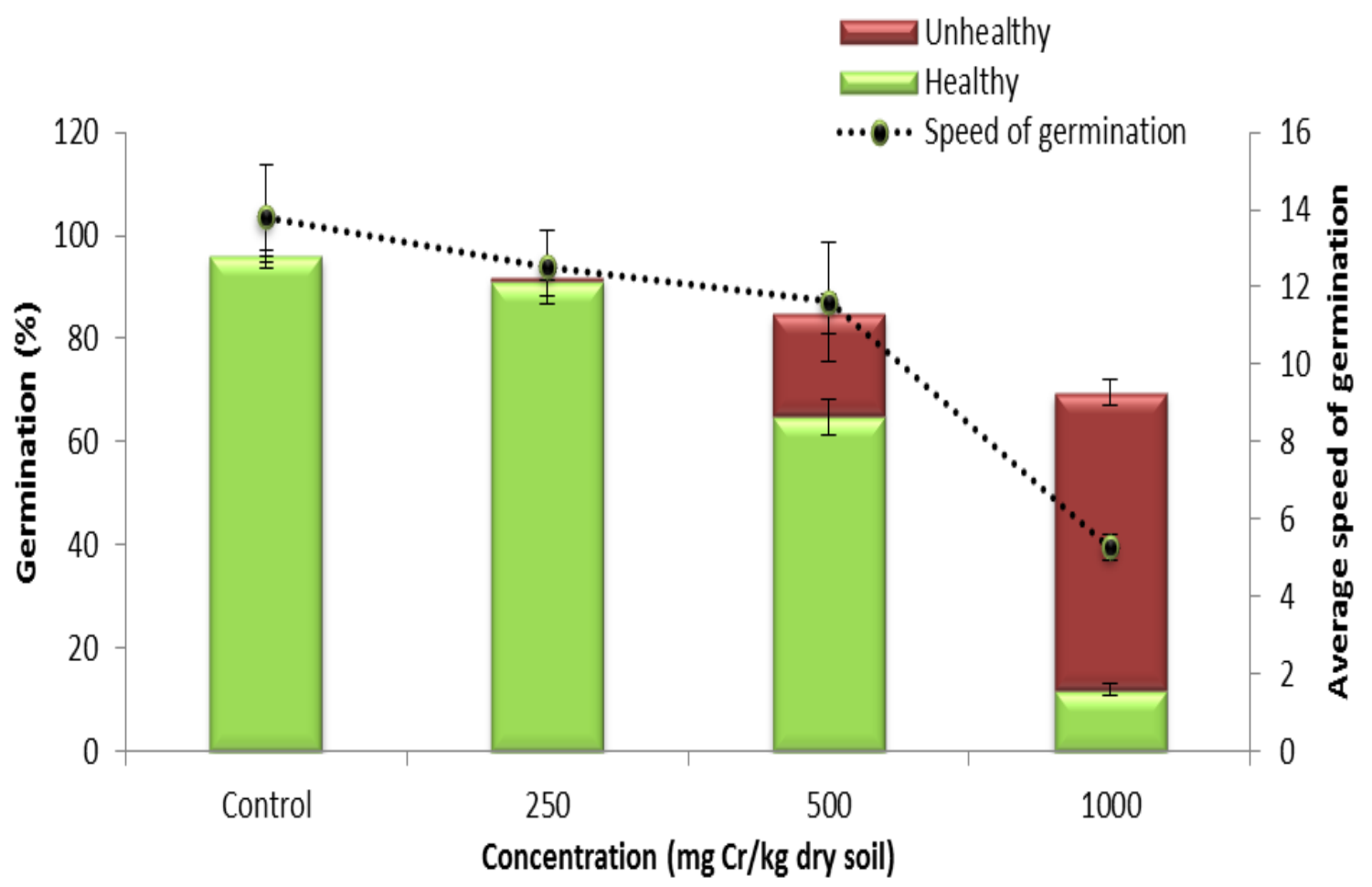


R. sativus

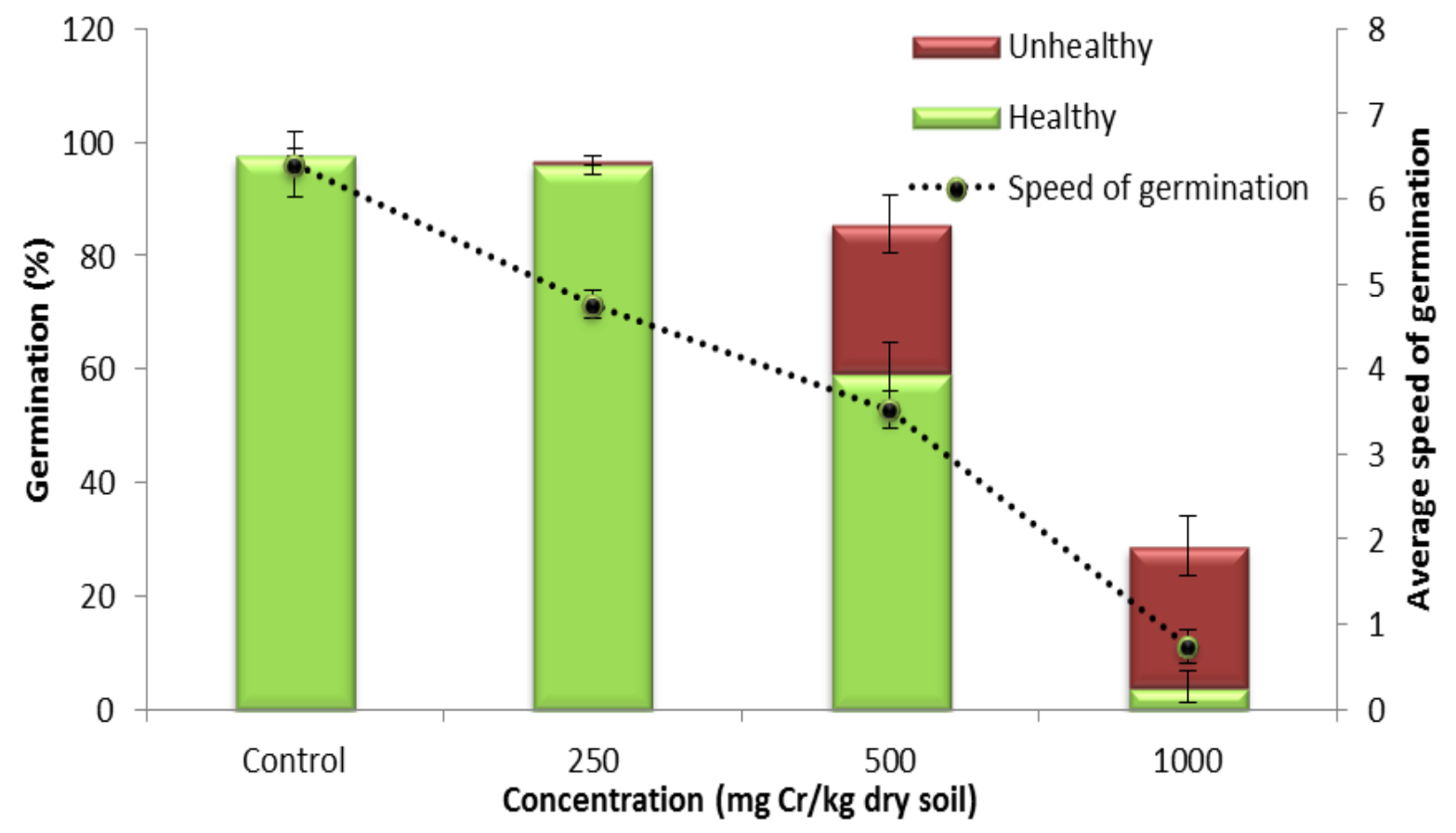

S. lycopersicum

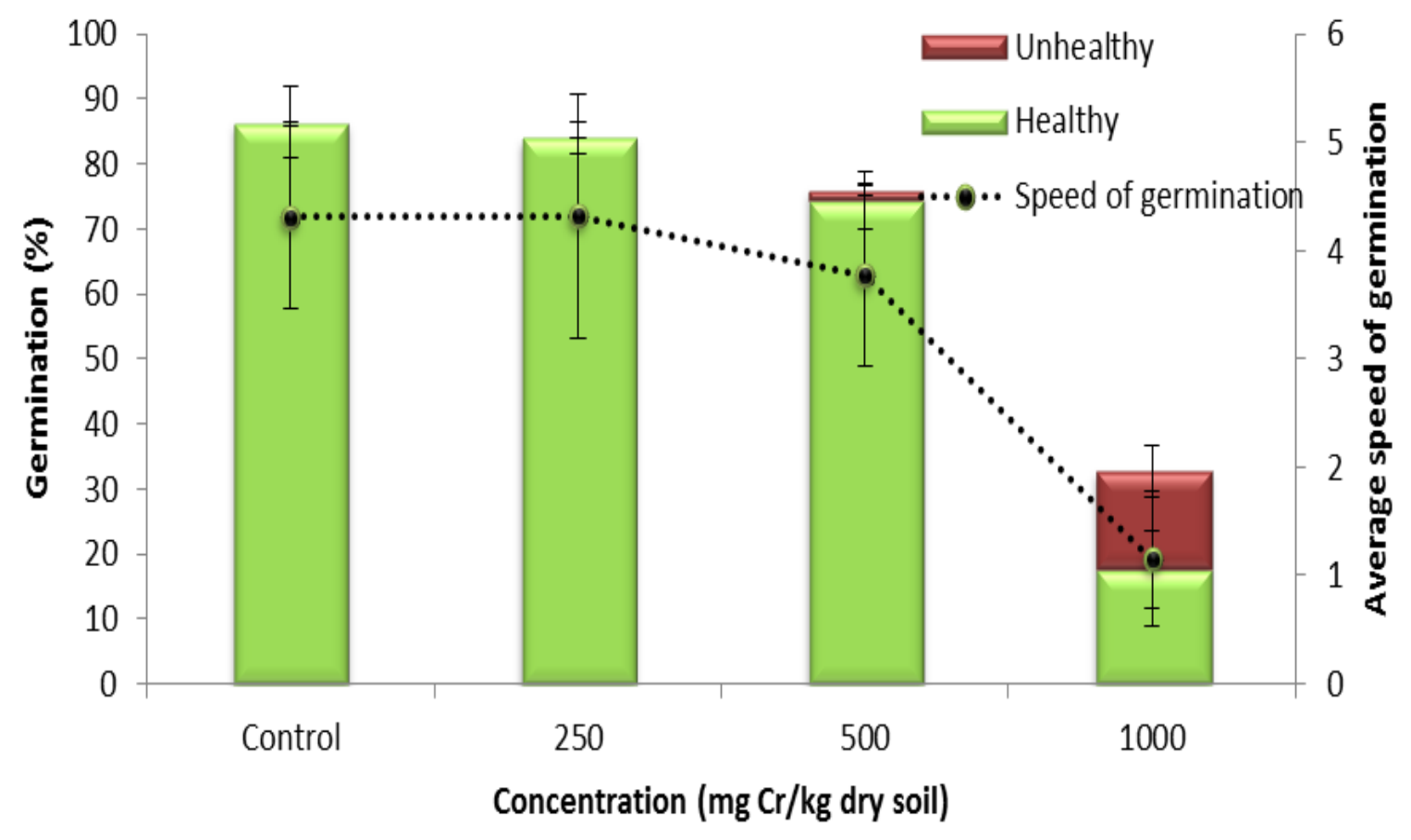




\section{M. sativa}

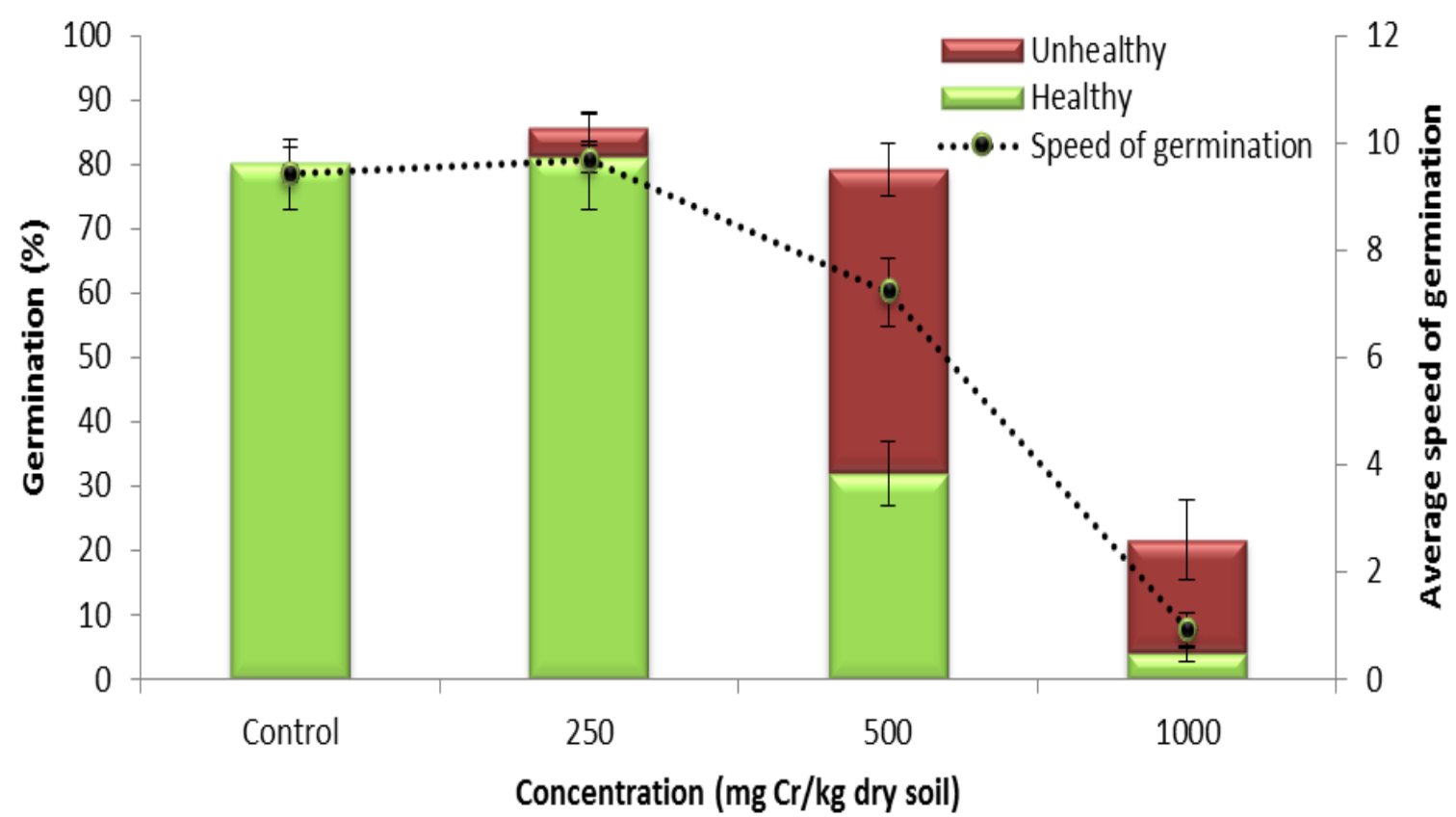

T. pratense

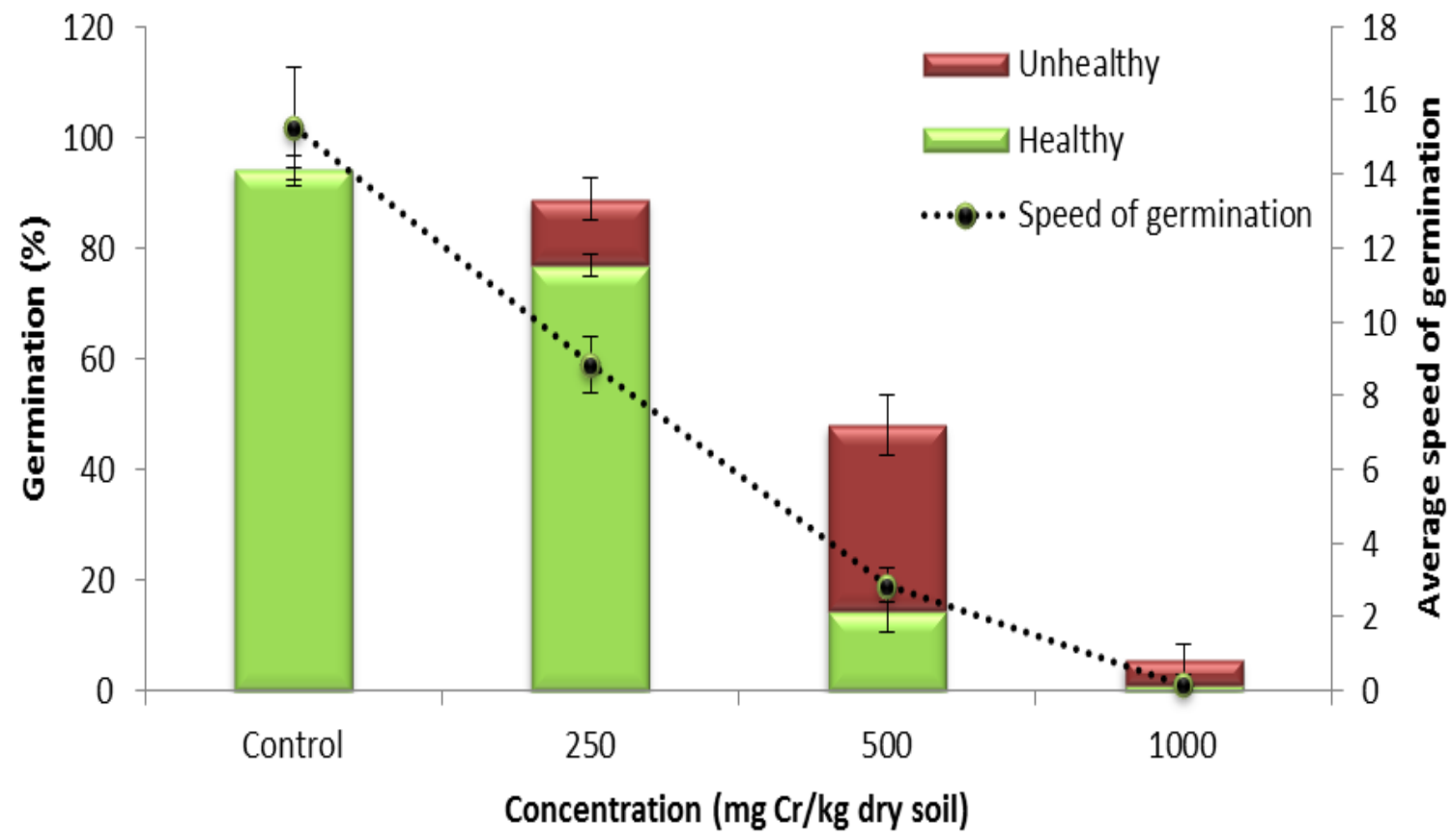




\section{B. juncea}

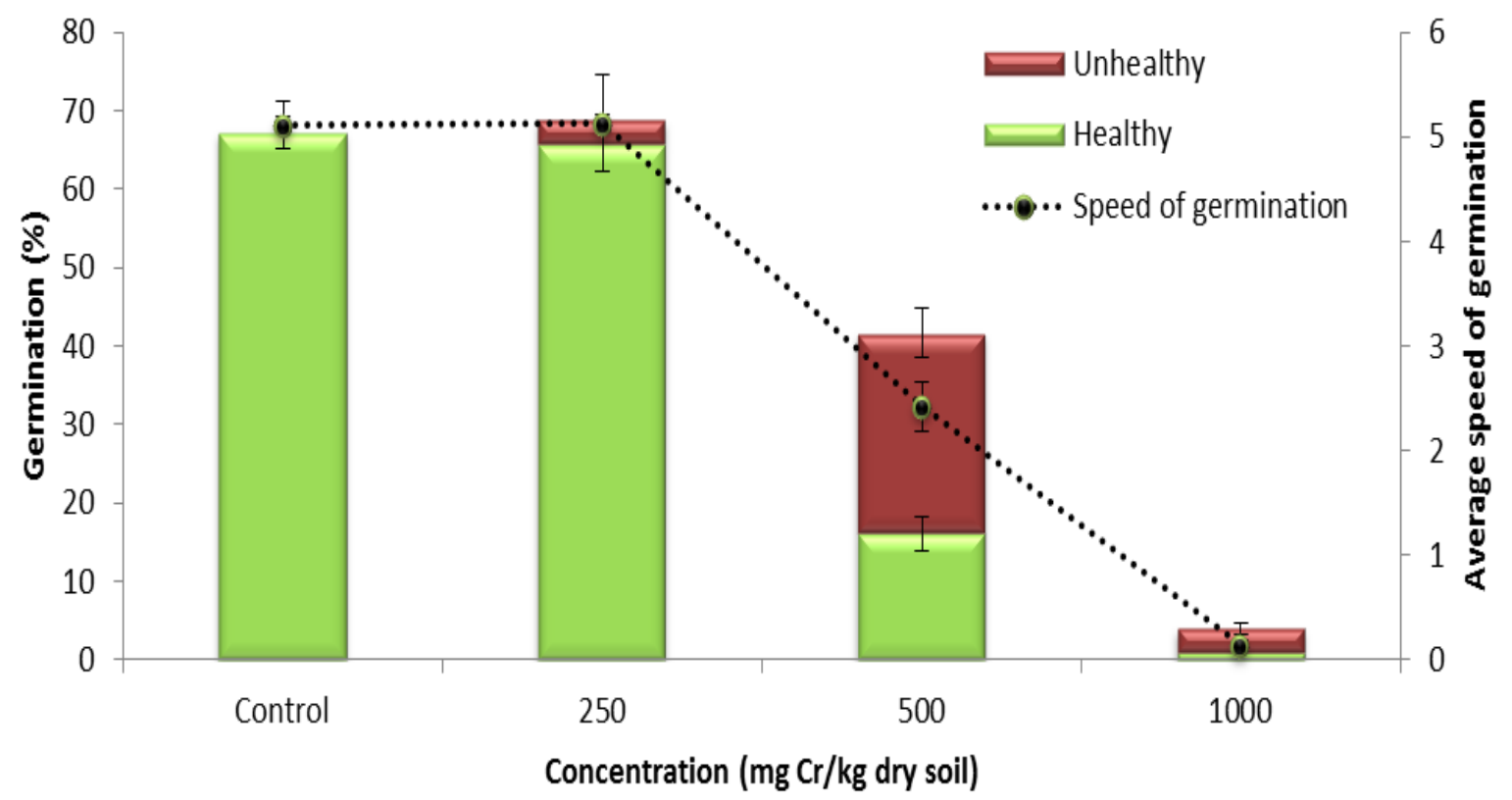

N. officinale

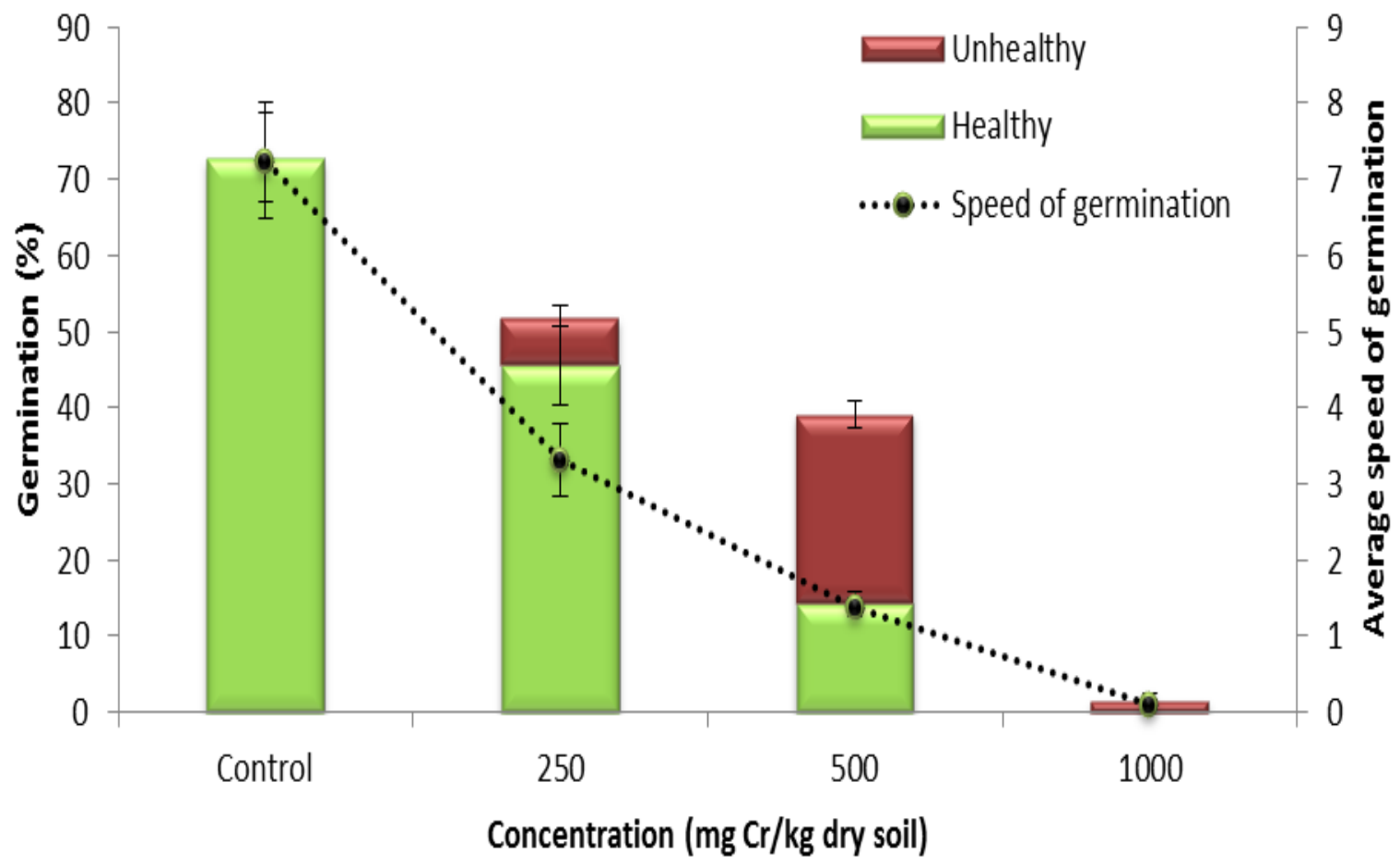


Appendix 4: Summary of the statistical results for total germination [in clear] and seedling health [in grey] of 32 tested plant species exposed to chromium (CrIII) in the concentration-response experiments without stratification and nine plant species exposed to CrIII in the concentration-response experiments with stratification. Cochran-Armitage trend test (Z-statistics/p-value) was conducted to test for trends in response amongst chromium treatments plus controls. Pairwise Fisher's Exact Test (p-value) was performed to compare responses in each independent CrIII treatment to controls. Significant differences amongst chromium concentrations for all tested plants are highlighted in bold.

\begin{tabular}{|c|c|c|c|c|c|}
\hline \multirow{2}{*}{ Condition } & \multirow{2}{*}{ Selected species } & \multirow{2}{*}{ Cochran-Armitage Test } & \multicolumn{3}{|c|}{ Fisher's Exact Test } \\
\hline & & & 250 & 500 & 1000 \\
\hline \multirow[t]{15}{*}{ Non-stratified } & \multirow[t]{2}{*}{ A. balsamea } & $10.8440 /<\mathbf{0 . 0 0 1}$ & 0.123 & $<0.001$ & $<0.001$ \\
\hline & & $10.8973 /<\mathbf{0 . 0 0 1}$ & 0.123 & $<0.001$ & $<0.001$ \\
\hline & \multirow[t]{2}{*}{ P. mariana } & $5.7110 /<\mathbf{0 . 0 0 1}$ & 0.500 & 0.032 & $<0.001$ \\
\hline & & $5.7110 /<\mathbf{0 . 0 0 1}$ & 0.500 & 0.032 & $<0.001$ \\
\hline & \multirow[t]{2}{*}{ P. banksiana } & $5.4479 /<\mathbf{0 . 0 0 1}$ & 0.285 & 0.205 & $<0.001$ \\
\hline & & $7.5749 /<\mathbf{0 . 0 0 1}$ & 0.285 & 0.205 & $<0.001$ \\
\hline & \multirow[t]{2}{*}{ P. virgatum } & $6.0061 /<\mathbf{0 . 0 0 1}$ & $<0.001$ & 0.002 & $<0.001$ \\
\hline & & $6.0061 /<\mathbf{0 . 0 0 2}$ & $<0.001$ & 0.002 & $<0.001$ \\
\hline & \multirow[t]{2}{*}{ P. palustris } & $12.7414 /<\mathbf{0 . 0 0 1}$ & 0.199 & $<0.001$ & $<0.001$ \\
\hline & & $12.7414 /<\mathbf{0 . 0 0 1}$ & 0.199 & $<0.001$ & $<0.001$ \\
\hline & \multirow[t]{2}{*}{ A. americanus } & $6.7475 /<\mathbf{0 . 0 0 1}$ & $<0.001$ & $<0.001$ & $<0.001$ \\
\hline & & $7.9616 /<\mathbf{0 . 0 0 1}$ & $<0.001$ & $<0.001$ & $<0.001$ \\
\hline & \multirow[t]{2}{*}{ P. tremuloides } & $2.1166 / \mathbf{0 . 0 1 8}$ & 0.883 & 0.500 & 0.064 \\
\hline & & $5.4408 /<\mathbf{0 . 0 0 1}$ & 0.883 & 0.043 & $<0.001$ \\
\hline & G. procumbens & $4.0878 /<\mathbf{0 . 0 0 1}$ & 0.351 & 0.158 & $<0.001$ \\
\hline
\end{tabular}




\begin{tabular}{|c|c|c|c|c|}
\hline & $4.3930 /<0.001$ & 0.351 & 0.026 & $<0.001$ \\
\hline \multirow[t]{2}{*}{ C. intybus } & $10.8177 /<\mathbf{0 . 0 0 1}$ & 0.551 & $<0.001$ & $<0.001$ \\
\hline & $10.7725 /<\mathbf{0 . 0 0 1}$ & 0.449 & $<0.001$ & $<0.001$ \\
\hline \multirow[t]{2}{*}{ T. officinale } & $9.6556 /<\mathbf{0 . 0 0 1}$ & 0.004 & $<0.001$ & $<0.001$ \\
\hline & $10.8189 /<\mathbf{0 . 0 0 1}$ & 0.002 & $<0.001$ & $<0.001$ \\
\hline \multirow[t]{2}{*}{ S. canadensis } & $1.7621 / \mathbf{0 . 0 4 2}$ & 0.288 & 0.500 & 0.040 \\
\hline & $3.8388 /<\mathbf{0 . 0 0 1}$ & 0.288 & 0.288 & $<0.001$ \\
\hline \multirow[t]{2}{*}{ E. maculatum } & $4.9235 /<\mathbf{0 . 0 0 1}$ & 0.138 & 0.006 & $<0.001$ \\
\hline & $6.2792 /<\mathbf{0 . 0 0 1}$ & 0.105 & $<0.001$ & $<0.001$ \\
\hline \multirow[t]{2}{*}{ D. canadense } & $7.2800 /<\mathbf{0 . 0 0 1}$ & 0.211 & 0.259 & $<0.001$ \\
\hline & $12.3265 /<\mathbf{0 . 0 0 1}$ & $<0.001$ & $<0.001$ & $<0.001$ \\
\hline \multirow[t]{2}{*}{ N. cataria } & $8.5174 /<\mathbf{0 . 0 0 1}$ & 0.008 & $<0.001$ & $<0.001$ \\
\hline & $8.9329 /<\mathbf{0 . 0 0 0 1}$ & 0.005 & $<0.001$ & $<0.001$ \\
\hline \multirow[t]{2}{*}{ M. officinalis } & $16.8515 /<\mathbf{0 . 0 0 1}$ & 0.596 & $<0.001$ & $<0.001$ \\
\hline & $16.8740 /<0.001$ & 0.596 & $<0.001$ & $<0.001$ \\
\hline \multirow[t]{2}{*}{ M. arvensis } & $9.7081 /<\mathbf{0 . 0 0 1}$ & $<0.001$ & $<0.001$ & $<0.001$ \\
\hline & $9.7530 /<\mathbf{0 . 0 0 1}$ & $<0.001$ & $<0.001$ & $<0.001$ \\
\hline \multirow[t]{2}{*}{ S. officinalis } & $14.2596 /<\mathbf{0 . 0 0 1}$ & 0.567 & $<0.001$ & $<0.001$ \\
\hline & $14.4198 /<\mathbf{0 . 0 0 1}$ & $<0.001$ & $<0.001$ & $<0.001$ \\
\hline \multirow[t]{2}{*}{ R. acetosa } & $7.4310 /<\mathbf{0 . 0 0 1}$ & 0.896 & 0.061 & $<0.001$ \\
\hline & $13.3390 /<0.001$ & 0.896 & $<0.001$ & $<0.001$ \\
\hline \multirow[t]{2}{*}{ C. album } & $2.5673 / \mathbf{0 . 0 0 5}$ & 0.658 & 0.122 & 0.021 \\
\hline & $3.6675 /<\mathbf{0 . 0 0 1}$ & 0.582 & 0.021 & $<0.001$ \\
\hline \multirow[t]{2}{*}{ A. syriaca } & $8.2930 /<\mathbf{0 . 0 0 1}$ & 0.082 & $<0.001$ & $<0.001$ \\
\hline & $11.4559 /<\mathbf{0 . 0 0 1}$ & 0.049 & $<0.001$ & $<0.001$ \\
\hline H. perforatum & $1.1414 / 0.134$ & 0.654 & 0.447 & 0.207 \\
\hline
\end{tabular}




$\begin{array}{ccccc} & 6.6530 /<\mathbf{0 . 0 0 1} & 0.654 & 0.064 & <\mathbf{0 . 0 0 1} \\ \text { U. dioica } & 4.5041 /<\mathbf{0 . 0 0 1} & \mathbf{0 . 0 1 3} & <\mathbf{0 . 0 0 1} & <\mathbf{0 . 0 0 1} \\ \text { V. hastata } & 4.9019 /<\mathbf{0 . 0 0 1} & \mathbf{0 . 0 1 3} & <\mathbf{0 . 0 0 1} & <\mathbf{0 . 0 0 1} \\ & 6.5499 /<\mathbf{0 . 0 0 1} & 0.127 & 0.127 & <\mathbf{0 . 0 0 1} \\ \text { H. moscheutos } & 7.6853 /<\mathbf{0 . 0 0 1} & 0.127 & 0.050 & <\mathbf{0 . 0 0 1} \\ & 5.6383 /<\mathbf{0 . 0 0 1} & 0.306 & \mathbf{0 . 0 0 5} & <\mathbf{0 . 0 0 1} \\ \text { A. rosea } & 8.3574 /<\mathbf{0 . 0 0 1} & \mathbf{0 . 0 3 8} & <\mathbf{0 . 0 0 1} & <\mathbf{0 . 0 0 1} \\ & 6.6834 /<\mathbf{0 . 0 0 1} & 0.776 & \mathbf{0 . 0 1 3} & <\mathbf{0 . 0 0 1} \\ \text { I. purpurea } & 8.7099 /<\mathbf{0 . 0 0 1} & 0.737 & <\mathbf{0 . 0 0 1} & <\mathbf{0 . 0 0 1} \\ & 6.3887 /<\mathbf{0 . 0 0 1} & 0.143 & \mathbf{0 . 0 0 4} & <\mathbf{0 . 0 0 1} \\ \text { R. sativus } & 15.4151 /<\mathbf{0 . 0 0 1} & 0.098 & <\mathbf{0 . 0 0 1} & <\mathbf{0 . 0 0 1} \\ & 14.0648 /<\mathbf{0 . 0 0 1} & 0.361 & <\mathbf{0 . 0 0 1} & <\mathbf{0 . 0 0 1} \\ \text { S. lycopersicum } & 17.2658 /<\mathbf{0 . 0 0 1} & 0.361 & <\mathbf{0 . 0 0 1} & <\mathbf{0 . 0 0 1} \\ & 9.9940 /<\mathbf{0 . 0 0 1} & 0.361 & \mathbf{0 . 0 2 6} & <\mathbf{0 . 0 0 1} \\ \text { M. sativa } & 12.4121 /<\mathbf{0 . 0 0 1} & 0.361 & \mathbf{0 . 0 1 3} & <\mathbf{0 . 0 0 1} \\ & 10.8828 /<\mathbf{0 . 0 0 1} & 0.910 & 0.500 & <\mathbf{0 . 0 0 1} \\ \text { T. pratense } & 13.8806 /<\mathbf{0 . 0 0 1} & 0.625 & <\mathbf{0 . 0 0 1} & <\mathbf{0 . 0 0 1} \\ & 15.9349 /<\mathbf{0 . 0 0 1} & 0.085 & <\mathbf{0 . 0 0 1} & <\mathbf{0 . 0 0 1}\end{array}$




\begin{tabular}{ccccc} 
& $12.1052 /<\mathbf{0 . 0 0 1}$ & 0.364 & $<\mathbf{0 . 0 0 1}$ & $<\mathbf{0 . 0 0 1}$ \\
P. banksiana & $9.6100 /<\mathbf{0 . 0 0 1}$ & 0.740 & 0.131 & $<\mathbf{0 . 0 0 1}$ \\
G. procumbens & $11.1029 /<\mathbf{0 . 0 0 1}$ & 0.740 & $\mathbf{0 . 0 1 8}$ & $<\mathbf{0 . 0 0 1}$ \\
& $5.5717 /<\mathbf{0 . 0 0 1}$ & $\mathbf{0 . 0 0 3}$ & $<\mathbf{0 . 0 0 1}$ & $<\mathbf{0 . 0 0 1}$ \\
S. canadensis & $5.5717 /<\mathbf{0 . 0 0 1}$ & $\mathbf{0 . 0 0 3}$ & $<\mathbf{0 . 0 0 1}$ & $<\mathbf{0 . 0 0 1}$ \\
& $2.5971 / \mathbf{0 . 0 0 5}$ & 0.997 & 0.425 & 0.073 \\
E. maculatum & $4.0420 /<\mathbf{0 . 0 0 1}$ & 0.992 & 0.111 & $\mathbf{0 . 0 0 1}$ \\
& $3.1697 /<\mathbf{0 . 0 0 1}$ & $\mathbf{0 . 0 0 9}$ & $\mathbf{0 . 0 4 2}$ & $<\mathbf{0 . 0 0 1}$ \\
A. syriaca & $3.5801 /<\mathbf{0 . 0 0 1}$ & $\mathbf{0 . 0 0 9}$ & $\mathbf{0 . 0 4 2}$ & $<\mathbf{0 . 0 0 1}$ \\
& $10.8867 /<\mathbf{0 . 0 0 1}$ & $<\mathbf{0 . 0 0 1}$ & $<\mathbf{0 . 0 0 1}$ & $<\mathbf{0 . 0 0 1}$ \\
H. perforatum & $11.8598 /<\mathbf{0 . 0 0 1}$ & $<\mathbf{0 . 0 0 1}$ & $<\mathbf{0 . 0 0 1}$ & $<\mathbf{0 . 0 0 1}$ \\
& $8.6934 /<\mathbf{0 . 0 0 1}$ & $<\mathbf{0 . 0 0 1}$ & $<\mathbf{0 . 0 0 1}$ & $<\mathbf{0 . 0 0 1}$ \\
V. hastata & $9.3885 /<\mathbf{0 . 0 0 1}$ & $<\mathbf{0 . 0 0 1}$ & $<\mathbf{0 . 0 0 1}$ & $<\mathbf{0 . 0 0 1}$ \\
& $4.4261 /<\mathbf{0 . 0 0 1}$ & $\mathbf{< . 0 0 1}$ & $<\mathbf{0 . 0 0 1}$ & $<\mathbf{0 . 0 0 1}$ \\
& $4.5264 /<\mathbf{0 . 0 0 1}$ & $<\mathbf{0 . 0 0 1}$ & $<\mathbf{0 . 0 0 1}$ & $<\mathbf{0 . 0 0 1}$ \\
\hline
\end{tabular}


Appendix 5: Summary of the statistical results for speed of total germination (SG) of seeds of 32 plant species exposed to CrIII in the concentration-response experiments without stratification and nine plant species exposed to CrIII in the concentration-response experiments with stratification. To test if chromium had an effect on how fast seeds germinate over the experiment period, either oneway ANOVA (F-value/df/p-value) or Kruskal-Wallis* ( $\mathrm{X}^{2}$-value/df/p-value) tests were conducted. Significant differences were further tested with either Dunnett's or Savage post-hoc tests (Iman \& Conover, 1987). Significant differences for SG are highlighted in bold. The lowest observed effect on speed of germination at tested chromium concentration (in $\mathrm{mg} \mathrm{kg}^{-1}$ ) was estimated using the post-hoc tests. N/E represents the cases where no significant effect amongst chromium treatments was observed.

\begin{tabular}{cccccc}
\hline Condition & Selected species & \multicolumn{2}{c}{ Statistics } & & $\begin{array}{c}\text { Lowest } \\
\text { observed effect } \\
\left(\mathrm{mg} \mathrm{kg}^{-1}\right)\end{array}$ \\
\hline Non-stratified & A. balsamea & $17.6226^{*}$ & 3 & $<\mathbf{0 . 0 0 1}$ & 250 \\
& P. mariana & 11.79 & 3,16 & $<\mathbf{0 . 0 0 1}$ & 500 \\
P. banksiana & 32.05 & 3,16 & $<\mathbf{0 . 0 0 1}$ & 500 \\
P. virgatum & $14.7368^{*}$ & 3 & $\mathbf{0 . 0 0 2}$ & 250 \\
P. palustris & 93.13 & 3,16 & $<\mathbf{0 . 0 0 1}$ & 250 \\
A. americanus & $10.6739^{*}$ & 3 & $\mathbf{0 . 0 1 4}$ & 250 \\
P. tremuloides & 10.13 & 3,16 & $<\mathbf{0 . 0 0 1}$ & 500 \\
G. procumbens & $14.1753^{*}$ & 3 & $\mathbf{0 . 0 0 3}$ & 250 \\
C. intybus & $16.8070^{*}$ & 3 & $<\mathbf{0 . 0 0 1}$ & 500 \\
T. officinale & $16.5210^{*}$ & 3 & $<\mathbf{0 . 0 0 1}$ & 250 \\
S. canadensis & 6.64 & 3,16 & $\mathbf{0 . 0 0 4}$ & 1000 \\
E. maculatum & 5.62 & 3,16 & $\mathbf{0 . 0 0 8}$ & 1000 \\
D. canadense & 16.75 & 3,16 & $<\mathbf{0 . 0 0 1}$ & 1000 \\
N. cataria & $16.2065^{*}$ & 3 & $<\mathbf{0 . 0 0 1}$ & 250 \\
M. officinalis & $17.7343^{*}$ & 3 & $<\mathbf{0 . 0 0 1}$ & 500
\end{tabular}




$\begin{array}{ccccc}\text { M. arvensis } & 17.4599^{*} & 3 & <\mathbf{0 . 0 0 1} & 250 \\ \text { S. officinalis } & 15.5943^{*} & 3 & <\mathbf{0 . 0 0 1} & 500 \\ \text { R. acetosa } & 15.8914^{*} & 3 & <\mathbf{0 . 0 0 1} & 250 \\ \text { C. album } & 10.0299^{*} & 3 & \mathbf{0 . 0 1 8} & 500 \\ \text { A. syriaca } & 19.49 & 3,16 & <\mathbf{0 . 0 0 1} & 500 \\ \text { H. perforatum } & 4.31 & 3,16 & \mathbf{0 . 0 2 1} & \mathrm{N} / \mathrm{E}^{\mathrm{a}} \\ \text { U. dioica } & 12.3924^{*} & 3 & \mathbf{0 . 0 0 6} & 250 \\ \text { V. hastata } & 18.14 & 3,16 & <\mathbf{0 . 0 0 1} & 1000 \\ \text { H. } \text { moscheutos } & 13.4330^{*} & 3 & \mathbf{0 . 0 0 4} & 500 \\ \text { A. rosea } & 11.69 & 3,16 & <\mathbf{0 . 0 0 1} & 500 \\ \text { I. purpurea } & 11.05 & 3,16 & <\mathbf{0 . 0 0 1} & 1000 \\ \text { R. sativus } & 89.31 & 3,16 & <\mathbf{0 . 0 0 1} & 250 \\ \text { S. } \text { lycopersicum } & 14.83 & 3,16 & <\mathbf{0 . 0 0 1} & 1000 \\ \text { M. sativa } & 13.0739^{*} & 3 & \mathbf{0 . 0 0 5} & 500 \\ \text { T. pratense } & 17.5961^{*} & 3 & <\mathbf{0 . 0 0 1} & 250 \\ \text { B. juncea } & 16.1457^{*} & 3 & <\mathbf{0 . 0 0 1} & 500 \\ \text { N. officinale } & 17.9245^{*} & 3 & <\mathbf{0 . 0 0 1} & 250 \\ \text { A. balsamea } & 16.8122^{*} & 3 & <\mathbf{0 . 0 0 1} & 250 \\ \text { P. } \text { mariana } & 17.8571^{*} & 3 & <\mathbf{0 . 0 0 1} & 250 \\ \text { P. banksiana } & 26.48 & 3,16 & <\mathbf{0 . 0 0 1} & 250 \\ \text { G. procumbens } & 14.5621^{*} & 3 & \mathbf{0 . 0 0 2} & 250 \\ \text { S. canadensis } & 9.8382^{*} & 3 & \mathbf{0 . 0 2} & 500 \\ \text { E. } \text { maculatum } & 3.4471^{*} & 3 & 0.328 & \mathrm{~N} / \mathrm{E} \\ \text { A. syriaca } & 16.6021^{*} & 3 & <\mathbf{0 . 0 0 1} & 250 \\ \text { H. perforatum } & 11.1674^{*} & 3 & \mathbf{0 . 0 1 1} & 250\end{array}$




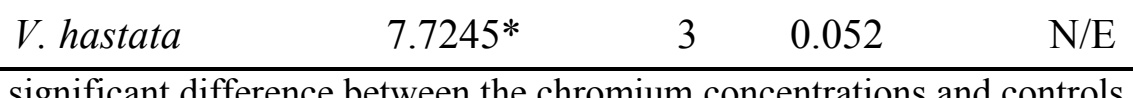


Appendix 6: Effective concentrations (EC10, EC25 and EC50) causing 10\%, 25\% and 50\% reduction in species germination are presented with confidence intervals (CI). Probit model (with appropriate distribution) or non-parametric interpolation method (ICPIN) (Norberg-King, 1993) were used to calculate the EC values. N/E represents the four cases where non-monotonic concentrationresponse of species to chromium was observed. Dashes (-) represents the cases for five tested plant species where calculated ECs were exceeding the maximum concentrations tested.

\begin{tabular}{cccccc}
\hline \multirow{2}{*}{ Condition } & Selected species & Distribution & EC10 [95\% CI $]$ & EC25[95\% CI] & EC50[95\% CI] \\
\hline Non-stratified & A. balsamea & Gompertz & $247.4[117.2-370.4]$ & $440.8[267.7-582.1]$ & $730.9[543.4-877.8]$ \\
& P. mariana & Normal & $549.6[95.1-838.1]$ & $996.1[479.0-1333]$ & $1929[1436-4487]$ \\
& P. banksiana & ICPIN & $778.3[618.2-879.2]$ & - & - \\
& P. virgatum & Gompertz & $33.3[0-157.1]$ & $111.4[0-305.3]$ & $321.0[0-581.0]$ \\
& P. palustris & Gompertz & $513.6[191.8-743.7]$ & $799.5[434.3-1017.0]$ & $1178.0[869.4-1366.0]$ \\
& A. americanus & ICPIN & $24.7[20.2-60.2]$ & $65.8[40.0-346.5]$ & $327.1[129.6-689.1]$ \\
P. tremuloides & N/E & - & - & - \\
G. procumbens & ICPIN & $57.5[11.4-860.8]$ & $484.4[29.0-930.1]$ & $919.2[176.1-1058.3]$ \\
C. intybus & ICPIN & $377.3[108.2-416.4]$ & $509.6[408.4-668.0]$ & $771.1[630.7-860.0]$ \\
T. officinale & Logistic & $137.4[30.2-237.7]$ & $246.0[93.2-364.5]$ & $440.3[266.3-605.1]$ \\
S. canadensis & N/E & - & - & - \\
E. maculatum & ICPIN & $23.1[10.3-416.8]$ & $193.2[29.8-755.8]$ & $711.9[157.3-914.4]$ \\
D. canadense & ICPIN & $758.8[199.0-914.6]$ & $1238.4[839.6-1637.7]$ & - \\
N. cataria & Gompertz & $235.1[65.4-362.9]$ & $370.1[162.0-496.3]$ & $550.6[351.5-665.3]$ \\
M. officinalis & ICPIN & $301.7[270.8-330.1]$ & $399.3[348.9-543.9]$ & $633.3[492.3-752.7]$ \\
M. arvensis & Gompertz & $41.1[4.0-94.7]$ & $91.6[18.4-164.4]$ & $185.0[69.4-269.4]$ \\
S. officinalis & Normal & $331.9[207.1-432.7]$ & $457.2[328.4-574.1]$ & $652.6[514.7-837.0]$
\end{tabular}




\begin{tabular}{|c|c|c|c|c|c|}
\hline & R. acetosa & ICPIN & 756.0 [701.7-968.4] & 1051.9 [729.9-1332.8] & - \\
\hline & C. album & ICPIN & $454.3[35.3-741.7]$ & $524.2[432.4-861.6]$ & 702.4 [541.8-1249.8] \\
\hline & A. syriaca & Normal & 286.4 [116.2-450.7] & $555.6[316.6-765.0]$ & $1160.0[859.8-1544]$ \\
\hline & H. perforatum & $\mathrm{N} / \mathrm{E}$ & - & - & - \\
\hline & U. dioica & ICPIN & 9.1 [28.3-170.7] & 28.3 [17.8-183.3] & 170.7 [72.5-697.7] \\
\hline & $V$. hastata & ICPIN & $90.6[27.2-764.4]$ & $821.4[224.7-954.0]$ & - \\
\hline & H. moscheutos & Normal & $275.6[0-681]$ & $570.6[0-1121]$ & 1280 [240-3746] \\
\hline & A. rosea & Normal & $532.9[121.1-805.6]$ & 726.0 [260-1010] & $1024.0[573.8-1376]$ \\
\hline & I. purpurea & Gompertz & 659.0 [278.2-878.2] & $1264.0[981.1-1713]$ & $2235.0[1666-5458]$ \\
\hline & R. sativus & Normal & $471.7[384.6-542.4]$ & 629.5 [548.5-698.6] & 867.3 [788.6-955.1] \\
\hline & S. lycopersicum & Normal & $513.6[95.8-787.0]$ & $771.6[279.3-1056.0]$ & $1213.0[795.5-1688.0]$ \\
\hline & M. sativa & Normal & 814.9 [408.7-942.6] & 911.0 [569.4-1012.9] & 1031.2 [814.4-1108.7] \\
\hline & T. pratense & Gompertz & 488.1 [349.1-586.3] & $650.7[524.7-734.0]$ & 837.1 [745.0-899.2] \\
\hline & B. juncea & Normal & $439.7[345.0-507.0]$ & $527.5[442.4-589.0]$ & 645.8 [575.9-704.5] \\
\hline & N. officinale & Gompertz & 301.2 [156.9-413.5] & 453.9 [294.5-536.6] & $650.1[506.0-746.6]$ \\
\hline \multirow[t]{9}{*}{ Stratified } & A. balsamea & Logistic & $193.8[114.0-252.6]$ & $263.1[181.8-321.6]$ & 357.4 [283.2-418.8] \\
\hline & P. mariana & Normal & 390.2 [256.0-506.9] & $593.1[443.4-720.4]$ & $944.6[788.3-1103.0]$ \\
\hline & P. banksiana & Normal & $629.0[398.1-778.5]$ & $870.3[667.7-1006.0]$ & $1249.0[1094.0-1450.0]$ \\
\hline & G. procumbens & ICPIN & $8.8[7.6-13.9]$ & 25.7 [18.3-173.2] & 141.6 [73.8-464.9] \\
\hline & S. canadensis & $\mathrm{N} / \mathrm{E}$ & - & - & - \\
\hline & E. maculatum & ICPIN & 9.8 [8.4-709.7] & $25.0[17.8-806.2]$ & - \\
\hline & A. syriaca & Normal & $144.1[62.5-223.3]$ & 242.4 [133.7-334.6] & 431.9 [304.9-535.3] \\
\hline & H. perforatum & ICPIN & 11.8 [10.9-14.4] & $25.0[20.8-38.7]$ & 83.3 [58.3-186.8] \\
\hline & V. hastata & ICPIN & 8.7 [8.2-11.7] & $19.0[16.3-39.1]$ & $75.4[50.0-245.8]$ \\
\hline
\end{tabular}


Appendix 7: Summary of emerged plant species in large containers (uncontaminated soil) and concentration-response Petri dishes (chromium contaminated soil) from the seed bank soils collected near the shores of Bucheski Lake, Nibinamik, Ontario. Acontamination refers to contaminating the soil with four concentrations (i.e. control - [0], 250, 500 and $1000 \mathrm{mg} \mathrm{kg}^{-1}$ ) after one month stratification treatment. B-contamination refers to contaminating the soil with the same four concentrations including controls prior to one month stratification treatment. The concentration-response experiment occurred in a growth chamber from October $21^{\text {st }}, 2014$ to April 21 ${ }^{\text {st }}, 2015$.

\begin{tabular}{|c|c|c|c|c|c|c|c|c|c|}
\hline \multirow{2}{*}{ Emerged species } & \multirow[b]{2}{*}{ Large containers } & \multicolumn{4}{|c|}{ A-contamination } & \multicolumn{4}{|c|}{ B-contamination } \\
\hline & & 0 & 250 & 500 & 1000 & 0 & 250 & 500 & 1000 \\
\hline \multicolumn{10}{|c|}{ Gymnosperms } \\
\hline \multirow[t]{2}{*}{ P. mariana } & 1 & & & & & & & & \\
\hline & Angiosperms M & onoc & cots & & & & & & \\
\hline A. americanus & 2 & 2 & 2 & & & 1 & & & \\
\hline C. canadensis & 20 & 3 & 7 & 9 & 6 & 2 & & 4 & 6 \\
\hline \multicolumn{10}{|l|}{ Grass spp. 1} \\
\hline Grass spp. 2 & & & & & & 1 & & & \\
\hline \multicolumn{10}{|l|}{ Carex spp. 1} \\
\hline \multicolumn{10}{|l|}{ Carex spp. 2} \\
\hline \multicolumn{10}{|l|}{ Carex spp. 3} \\
\hline Carex spp. 4 & 1 & & & & & & & & \\
\hline \multicolumn{10}{|l|}{ Carex spp. 5} \\
\hline \multicolumn{10}{|c|}{ Dicots Woody } \\
\hline \multicolumn{10}{|l|}{ R. hudsonianum } \\
\hline D. lonicera & 80 & 7 & 5 & 3 & & 10 & 2 & 3 & 1 \\
\hline R. idaeus & 4 & & & & & & & & \\
\hline
\end{tabular}




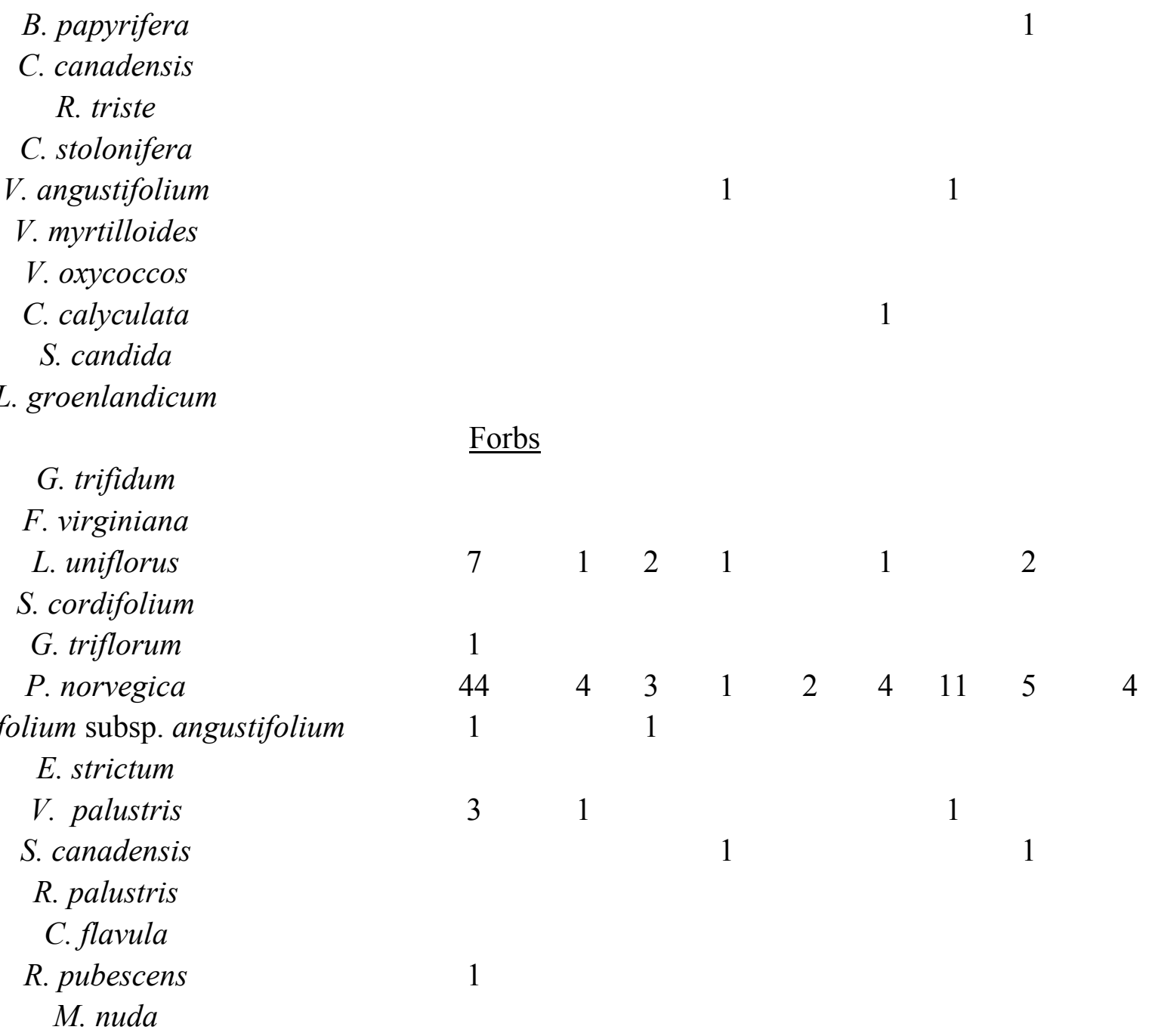


P. peltatum

Total number of seedlings

Total number of species
165

$18 \quad 20$

12
$6 \quad 6$
16

6

$\begin{array}{ccccc}20 & 15 & 16 & 11 \\ 2 & 7 & 4 & 6 & 3\end{array}$


Appendix 8: Summary of emerged plant species in large containers (uncontaminated soil) and concentration-response Petri dishes (chromium contaminated soil) from the seed bank soils collected in the uplands of boreal forest, Nibinamik, Ontario. A-contamination refers to contaminating the soil with four concentrations (i.e. control - [0], 250, 500 and $1000 \mathrm{mg} \mathrm{kg}^{-1}$ ) after one month stratification treatment. B-contamination refers to contaminating the soil with the same four concentrations including controls prior to one month stratification treatment. The concentration-response experiment occurred in a growth chamber from October $21^{\text {st }}, 2014$ to April $21^{\text {st }}$, 2015.

\begin{tabular}{|c|c|c|c|c|c|c|c|c|c|}
\hline \multirow{2}{*}{ Emerged species } & & \multicolumn{4}{|c|}{ A-contamination } & \multicolumn{4}{|c|}{ B-contamination } \\
\hline & Large containers & 0 & 250 & 500 & 1000 & 0 & 250 & 500 & 1000 \\
\hline \multicolumn{10}{|c|}{ Gymnosperms } \\
\hline \multicolumn{10}{|l|}{ P. mariana } \\
\hline \multicolumn{10}{|c|}{$\underline{\text { Angiosperms Monocots }}$} \\
\hline \multicolumn{10}{|l|}{ A. americanus } \\
\hline C. canadensis & 1 & 2 & & & & & 1 & & \\
\hline \multicolumn{10}{|l|}{ Grass spp. 1} \\
\hline Grass spp. 2 & 3 & & & & & 1 & & & \\
\hline Carex spp. 1 & 4 & & & 1 & & & & & \\
\hline Carex spp. 2 & 1 & & & & & & & & \\
\hline \multicolumn{10}{|l|}{ Carex spp. 3} \\
\hline \multicolumn{10}{|l|}{ Carex spp. 4} \\
\hline \multirow[t]{2}{*}{ Carex spp. 5} & & & & 1 & & & & & \\
\hline \multirow{2}{*}{\multicolumn{10}{|c|}{ Dicots Woody }} \\
\hline & & & & & & & & & \\
\hline D. lonicera & 1 & & & & & & & & \\
\hline R. idaeus & 2 & & & & & & & & \\
\hline
\end{tabular}




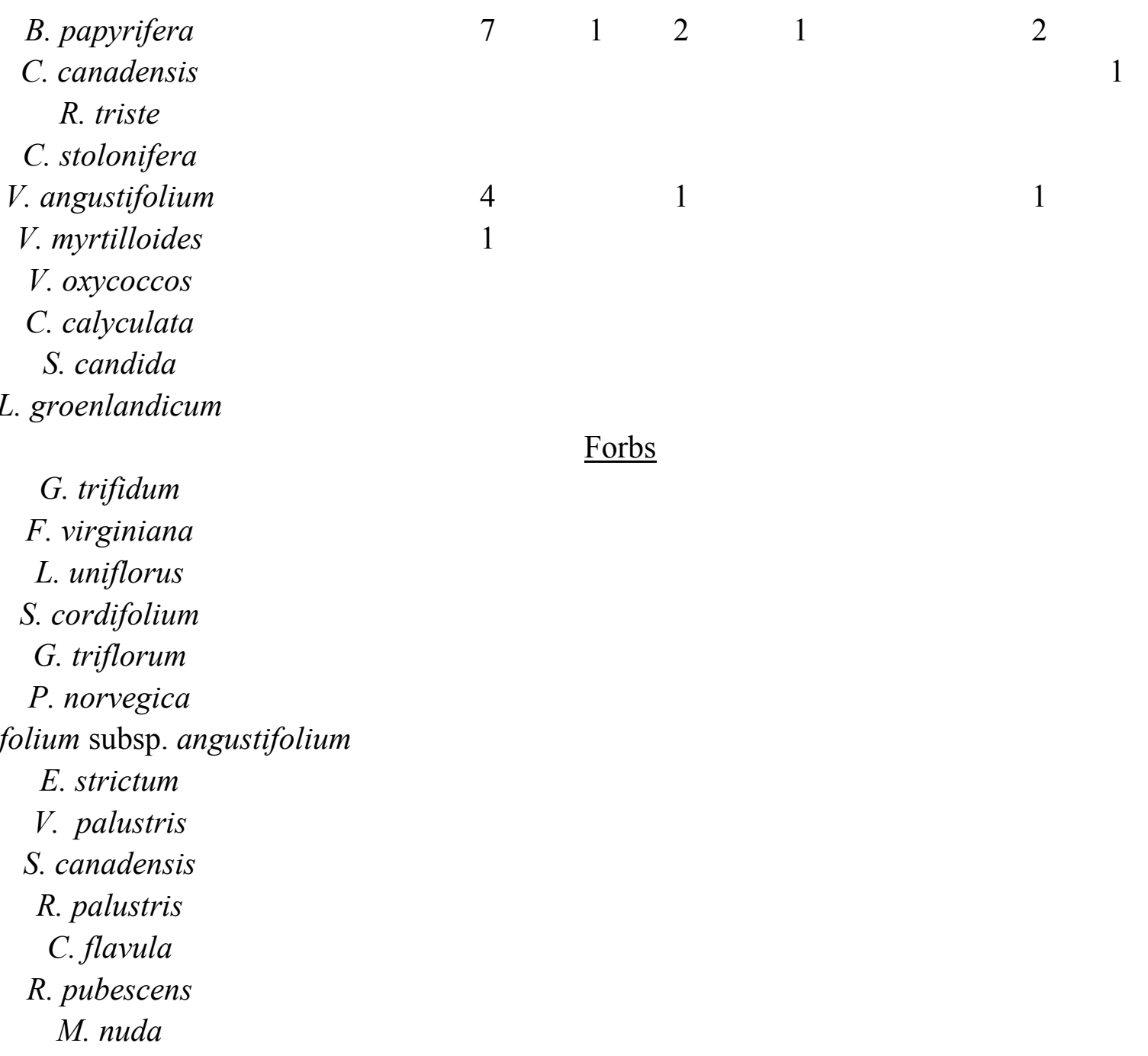


P. peltatum

Total number of seedlings

Total number of species
9 
Appendix 9: Summary of emerged plant species in large containers (uncontaminated soil) and concentration-response Petri dishes (chromium contaminated soil) from the seed bank soils collected in the wetland areas, Nibinamik, Ontario. A-contamination refers to contaminating the soil with four concentrations (i.e. control - [0], 250, 500 and $1000 \mathrm{mg} \mathrm{kg}^{-1}$ ) after one month stratification treatment. B-contamination refers to contaminating the soil with the same four concentrations including controls prior to one month stratification treatment. The concentration-response experiment occurred in a growth chamber from October $27^{\text {th }}, 2014$ to April $27^{\text {th }}, 2015$.

\begin{tabular}{|c|c|c|c|c|c|c|c|c|}
\hline \multirow{2}{*}{ Emerged species } & \multirow[b]{2}{*}{ Large containers } & \multicolumn{3}{|c|}{ A-contamination } & \multicolumn{4}{|c|}{ B-contamination } \\
\hline & & 0250 & 500 & 1000 & 0 & 250 & 500 & 1000 \\
\hline \multicolumn{9}{|c|}{ Gymnosperms } \\
\hline \multicolumn{9}{|l|}{ P. mariana } \\
\hline \multicolumn{9}{|c|}{ Angiosperms Monocots } \\
\hline \multicolumn{9}{|l|}{ A. americanus } \\
\hline C. canadensis & & & & & 1 & & & \\
\hline \multicolumn{9}{|l|}{ Grass spp. 1} \\
\hline \multicolumn{9}{|l|}{ Grass spp. 2} \\
\hline \multicolumn{9}{|l|}{ Carex spp. 1} \\
\hline \multicolumn{9}{|l|}{ Carex spp. 2} \\
\hline Carex spp. 3 & 1 & & & & & & & \\
\hline \multicolumn{9}{|l|}{ Carex spp. 4} \\
\hline \multirow[t]{2}{*}{ Carex spp. 5} & 1 & & & 4 & & 1 & 3 & \\
\hline & \multicolumn{8}{|c|}{ Dicots Woody } \\
\hline \multicolumn{9}{|l|}{ R. hudsonianum } \\
\hline \multicolumn{9}{|l|}{ D. lonicera } \\
\hline \multicolumn{9}{|l|}{ R. idaeus } \\
\hline B. papyrifera & & & & & & & & \\
\hline
\end{tabular}


C. canadensis
R. triste

C. stolonifera

$V$. angustifolium

V. myrtilloides

V. oxycoccos

C. calyculata

S. candida

L. groenlandicum

G. trifidum

$F$. virginiana

L. uniflorus

S. cordifolium

G. triflorum

P. norvegica

\section{$\underline{\text { Forbs }}$}

C. angustifolium subsp. angustifolium

$$
\begin{gathered}
\text { E. strictum } \\
\text { V. palustris } \\
\text { S. canadensis } \\
\text { R. palustris } \\
\text { C. flavula } \\
\text { R. pubescens } \\
\text { M. nuda } \\
\text { P. peltatum }
\end{gathered}
$$


Total number of seedlings

\begin{tabular}{lllllllll}
6 & 2 & 0 & 1 & 5 & 1 & 2 & 4 & 1 \\
4 & 1 & 0 & 1 & 2 & 1 & 2 & 2 & 1 \\
\hline
\end{tabular}


Appendix 10: Summary of emerged plant species in large containers (uncontaminated soil) and concentration-response Petri dishes (chromium contaminated soil) from the seed bank soils collected near the banks of Winisk River, Nibinamik, Ontario. Acontamination refers to contaminating the soil with four concentrations (i.e. control - [0], 250, 500 and $1000 \mathrm{mg} \mathrm{kg}^{-1}$ ) after one month stratification treatment. B-contamination refers to contaminating the soil with the same four concentrations including controls prior to one month stratification treatment. The concentration-response experiment occurred in a growth chamber from October $27^{\text {th }}, 2014$ to April $27^{\text {th }}, 2015$.

\begin{tabular}{|c|c|c|c|c|c|c|c|c|c|}
\hline \multirow{2}{*}{ Emerged species } & \multirow[b]{2}{*}{ Large containers } & \multicolumn{4}{|c|}{ A-contamination } & \multicolumn{4}{|c|}{ B-contamination } \\
\hline & & 0 & 250 & 500 & 1000 & 0 & 250 & 500 & 1000 \\
\hline \multicolumn{10}{|c|}{ Gymnosperms } \\
\hline \multicolumn{10}{|l|}{ P. mariana } \\
\hline \multicolumn{10}{|c|}{ Angiosperms Monocots } \\
\hline \multicolumn{10}{|l|}{ A. americanus } \\
\hline C. canadensis & & 1 & & & & 1 & & 1 & \\
\hline Grass spp. 1 & 3 & & & & & & & & \\
\hline \multicolumn{10}{|l|}{ Grass spp. 2} \\
\hline Carex spp. 1 & & & & & & 1 & & & \\
\hline Carex spp. 2 & & & 1 & & & & & & \\
\hline \multicolumn{10}{|l|}{ Carex spp. 3} \\
\hline \multicolumn{10}{|l|}{ Carex spp. 4} \\
\hline \multicolumn{10}{|l|}{ Carex spp. 5} \\
\hline \multicolumn{10}{|c|}{$\underline{\text { Dicots Woody }}$} \\
\hline R. hudsonianum & 4 & & & & & & 1 & & \\
\hline \multicolumn{10}{|l|}{ D. lonicera } \\
\hline R. idaeus & 1 & 1 & & & 1 & & & & \\
\hline
\end{tabular}




$$
\begin{gathered}
\text { B. papyrifera } \\
\text { C. canadensis } \\
\text { R. triste } \\
\text { C. stolonifera } \\
\text { V. angustifolium } \\
\text { V. myrtilloides } \\
\text { V. oxycoccos } \\
\text { C. calyculata } \\
\text { S. candida } \\
\text { L. groenlandicum }
\end{gathered}
$$

\section{G. trifidum}

F. virginiana

L. uniflorus

S. cordifolium

G. triflorum

P. norvegica

$\underline{\text { Forbs }}$

1

5

1

2

C. angustifolium subsp. angustifolium
E. strictum
$V$. palustris
S. canadensis
R. palustris
C. flavula
R. pubescens
M. nuda 


\begin{tabular}{lllllllllll} 
P. peltatum & 1 & & & & & & & & \\
number of seedlings & 35 & 3 & 2 & 0 & 3 & 3 & 1 & 3 & 1 \\
al number of species & 18 & 3 & 2 & 0 & 3 & 3 & 1 & 3 & 1 \\
\hline
\end{tabular}

